\title{
Health effects assessment of exposure to particles from wood smoke
}

\author{
Nielsen, Elsa; Dybdahl, Marianne; Larsen, Poul Bo
}

Publication date:

2008

Document Version

Publisher's PDF, also known as Version of record

Link back to DTU Orbit

Citation (APA):

Nielsen, E., Dybdahl, M., \& Larsen, P. B. (2008). Health effects assessment of exposure to particles from wood smoke. Miljøstyrelsen. Environmental Project No. 12352008

\section{General rights}

Copyright and moral rights for the publications made accessible in the public portal are retained by the authors and/or other copyright owners and it is a condition of accessing publications that users recognise and abide by the legal requirements associated with these rights.

- Users may download and print one copy of any publication from the public portal for the purpose of private study or research.

- You may not further distribute the material or use it for any profit-making activity or commercial gain

- You may freely distribute the URL identifying the publication in the public portal

If you believe that this document breaches copyright please contact us providing details, and we will remove access to the work immediately and investigate your claim 


\section{Health effects assessment of exposure to particles from wood smoke}

Elsa N ielsen, Marianne Dybdahl

Department of Toxicology and Risk Assessment National Food Institute

Technical University of Denmark

Poul Bo Larsen

Danish Environmental Protection Agency

Environmental Project No. 12352008 Miljøprojekt 
The D anish Environmental Protection Agency will, when opportunity offers, publish reports and contributions relating to environmental research and development projects financed via the D anish EPA.

Please note that publication does not signify that the contents of the reports necessarily reflect the views of the $D$ anish EPA.

T he reports are, however, published because the D anish EPA finds that the studies represent a valuable contribution to the debate on environmental policy in D enmark. 


\section{Content}

CONTENT

PREFACE

$\begin{array}{ll}\text { SUMM ARY } & 7\end{array}$

HUMAN EXPOSURE TO PARTICLES FROM WOOD SMOKE

HUMAN HEALTH EFFECTS 8

$H$ uman non-cancer health effects from exposure to particles from
wood smoke

H uman carcinogenic effects from exposure to particles from
wood smoke

DATA FROM STUDIES IN EXPERIMENTAL ANIMALS 10

RISK CHARACTERISATION 10

RECOMMENDATIONS 12

SAM MENFATNING 13

BEFOLKNINGENS UDSATTELSE FOR PARTIKLER FRA BRÆNDERØG 13

HELBREDSEFFEKTER, DATA FRA BEFOLKNINGSUNDERSØGELSER 14

Partikler generelt $\quad 14$

Sundhedsskadelige effekter af partikler fra brænderøg 14

$\mathrm{K}$ ræftfremkaldende effekter af partikler fra brænderøg $\quad 15$

VIDEN FRA UNDERS $\varnothing$ GELSER MED FORS $\varnothing G S D Y R \quad 16$

RISIKOKARAKTERISERING

ANBEFALINGER 18

$\begin{array}{lll}1 & \text { INTRODUCTION } & 19\end{array}$

2 WOOD SMOKE, CHARACTERISATION 21

2.1 PARTICLE SIZE DISTRIBUTION 21

2.2 CHEMICAL CHARACTERISATION OF WOOD SMOKE 23

3 HUMAN EXPOSURE 27

3.1 EXPOSURE FROM AMBIENT AIR 27

$\begin{array}{lll}3.1 .1 & \text { Particles } & 27\end{array}$

$\begin{array}{lll}3.1 .2 & \mathrm{PAH} & 29\end{array}$

3.2 INDOOR PENETRATION 30

3.3 EXPOSURE FROM OTHER SETTINGS WITH WOOD SMOKE 31

3.4 SUMMARY OF HUMAN EXPOSURE TO PARTICLES FROM

4 TOXICOKINETICS 35

4.1 PARTICLE DEPOSITION IN THE RESPIRATORY TRACT 35

4.2 CLEARANCEAND TRANSLOCATION 35

5 HUMAN HEALTH EFFECTS 39

5.1 EPIDEMIOLOGICAL STUDIES, NON-CANCER HEALTH EFFECTS 40

5.1.1 Particles in the general environment 41

5.1.2 Particles from residential wood burning 43 
5.1.3 O ther settings with wood smoke exposure 52

5.1.4 Summary, non-cancer health effects $\quad 55$

5.2 EPIDEMIOLOGICAL STUDIES, CARCINOGENIC EFFECTS 57

$\begin{array}{ll}5.2 .1 \quad P \text { articles in the general environment } & 57\end{array}$

5.2.2 Particles from wood burning 58

$\begin{array}{ll}\text { 5.2.3 Summary, carcinogenic effects } & 60\end{array}$

6 EXPERIMENTAL ST UDIES 63

6.1 HUMAN STUDIES 63

6.2 STUDIESIN EXPERIMENTAL ANIMALS 63

6.2.1 Particles in the general environment, an overview 64

6.2.2 Particles from wood smoke 67

$\begin{array}{lll}6.3 & \text { IN VITRO STUDIES } & 73\end{array}$

6.4 SUMMARY, EXPERIMENTAL STUDIES

7 RISK ASSESSMENT, WOOD SMOKE PARTICLES

7.1 EXPOSURE ASSESSMENT

$\begin{array}{lll}7.2 & \text { HAZARD ASSESSMENT } & 79\end{array}$

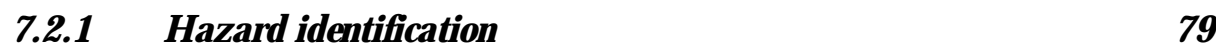

7.2.2 H azard characterisation / dose response relationship 81

7.3 RISK CHARACTERISATION 86

7.3.1 Estimated wood smoke PM exposure for risk characterisation 86

7.3.2 D ose response relationships for risk characterisation 87

8 CONCLUSIONS 91

8.1 EXPOSURE ASSESSMENT, WOOD SMOKE PM 91

8.2 HAZARD ASSESSMENT, WOOD SMOKE PM 91

8.3 RISK CHARACTERISATION, WOOD SMOKE PM 92

9 GAPS OF KNOWLEDGE 95

9.1 CHARACTERISATION OF WOOD SMOKE PARTICLES 95

9.2 EXPOSURE ASSESSMENT 95

9.3 HAZARD ASSESSMENT / RISK CHARACTERISATION

9.4 MODE OF ACTION 96

9.5 RECOMMENDATIONS 96

$\begin{array}{lll}10 & \text { REFERENCES }\end{array}$ 


\section{Preface}

In recent years there has been an increased awareness regarding the health effects linked to pollution with particulate matter in the air. Special funds have been allocated to further research and development in this area by the $D$ anish EPA. T his project is a contribution to this work and the focus in this report is to assess human hazards and health impacts in connection with wood smoke emissions, as emissions from wood burning by far constitutes the largest source to the overall particulate matter emissions in D enmark.

T he report has been prepared by Elsa $N$ ielsen ( $D$ epartment of T oxicology and R isk A ssessment, $\mathrm{N}$ ational F ood Institute, T echnical U niversity of D enmark), $M$ arianne D ybdahl (D epartment of T oxicology and Risk A ssessment, $\mathrm{N}$ ational Food Institute, T echnical U niversity of $D$ enmark - until 30 June 2005), and Poul Bo L arsen ( $D$ anish Environmental Protection A gency), as a contract work for the $D$ anish Environmental Protection A gency.

T he work has been followed by a Steering Committee:

Steffen L oft, Institute of Public H ealth, U niversity of C openhagen.

$\mathrm{M}$ arianne $\mathrm{G}$ lasius, $\mathrm{T}$ he $\mathrm{N}$ ational Environmental R esearch Institute and A arhus U niversity.

$\mathrm{H}$ åkan W allin, T he $\mathrm{N}$ ational Institute of O ccupational $\mathrm{H}$ ealth.

Elsa N ielsen, D epartment of T oxicology and Risk A ssessment, $\mathrm{T}$ he $\mathrm{N}$ ational Food Institute, T echnical U niversity of D enmark.

$M$ ona- $L$ ise Binderup, D epartment of T oxicology and R isk A ssessment, T he $\mathrm{N}$ ational $\mathrm{F}$ ood Institute, T echnical U niversity of $\mathrm{D}$ enmark.

John C hristian L arsen, D epartment of T oxicology and R isk A ssessment, T he $N$ ational Food Institute, T echnical U niversity of D enmark.

Poul Bo L arsen, C hairman, D anish Environmental Protection Agency.

Christian L ange Fogh, D anish Environmental Protection Agency.

R asmus Brandt-L assen, D anish Environmental Protection A gency.

T he authors are solely responsible for all the assessments and conclusions presented in the report, and do not necessarily reflect the positions of the involved institutions.

T he authors want to thank the Steering Committee who has contributed to the work with professional expertise, proposals and criticism during the drafting of the report.

We also want to thank $L$ ars $D$ ragsted ( $D$ epartment of $T$ oxicology and Risk A ssessment, $T$ he $\mathrm{N}$ ational F ood Institute, T echnical U niversity of $D$ enmark until 31 D ecember 2006) for his valuable comments during the drafting of the report.

Finally we would like to thank the $D$ anish Environmental Protection Agency for the financial support. 


\section{Summary}

The number of residential wood burning devices has increased in D enmark during the latest years and it has been estimated that there in 2005 were about 551,000 wood stoves and about 48,000 wood boilers in D enmark. T his has resulted in an increased exposure of the general $D$ anish population to pollutants associated with residential wood smoke. $\mathrm{N}$ ew $\mathrm{D}$ anish monitoring results on particulate matter (PM) in ambient air have shown elevated PM levels in areas with many wood stoves, particularly during wintertime when wood burning is common. D ue to the size distribution of wood smoke particles essentially all will be contained in the $\mathrm{PM}_{2.5}$ fraction. It has been estimated that about 17,665 tonnes $\mathrm{PM}_{2.5}$ per year (2005) in D enmark come from residential wood combustion. T herefore, there is an increasing concern that adverse human health effects might be associated with the increased exposure to residential wood smoke.

T his project has been set up in order to review the scientific literature concerning adverse health effects of pollutants associated with residential wood smoke with the main focus on particulate matter and to quantify and evaluate, if possible, the impact on human health of the increased exposure to particles in residential wood smoke.

\section{Human exposure to particles from wood smoke}

T here is only very limited information on population exposure to wood smoke particles in D enmark.

M easurements during a 6-week winter period (2002 and 2003-2004) in a $D$ anish residential area with no district heating and many wood stoves showed that the contribution from wood combustion to ambient $\mathrm{PM}_{2.5}$ was comparable to the contribution from a heavily trafficked road to $\mathrm{PM}_{2.5}$ at the sidewalk. T he average local $\mathrm{PM}_{2.5}$ contribution from wood combustion was about $4 \mu \mathrm{g} / \mathrm{m}^{3}$. In another residential area with natural gas combustion as the primary heating source and wood combustion as a secondary heating source, the average $\mathrm{PM}_{2.5}$ concentration was elevated by about $1 \mu \mathrm{g} / \mathrm{m}^{3}$ compared to background measurements during four winter weeks. An increase in annual average $P M_{2.5}$ of $1 \mu \mathrm{g} / \mathrm{m}^{3}$ is a best maximum estimate of the whole $D$ anish population exposure based on the data from the measurements in these two residential areas.

Based on the total particle emission from residential wood burning, model calculations have been used to estimate the contribution to the annual PM ${ }_{2.5}$ levels. T he results showed an increase in annual $P_{2.5}$ of $0.2 \mu \mathrm{g} / \mathrm{m}^{3}$ (as a best minimum estimate) for the whole $D$ anish population exposure.

In conclusion, the annual average $\mathrm{PM}_{2.5}$ exposure from wood smoke is roughly estimated to be $0.2-1 \mu \mathrm{g} / \mathrm{m}^{3}$ for the whole $D$ anish population with a best estimate of about $0.6 \mu \mathrm{g} / \mathrm{m}^{3}$. 
T he sub-micrometer particles can easily penetrate into the indoor environment, especially if air filtration does not occur. A recent Swedish study has revealed that the outdoor-generated particle levels were major contributors to the indoor particle concentration when no strong internal source was present and the determined indoor-outdoor ratios varied between 0.5 and 0.8 .

\section{Human heal th effects}

The association of PM with adverse health effects has long been recognised, especially in relation to respiratory and cardio-vascular diseases and primarily in the elderly and in individuals with pre-existing respiratory and/or cardiac diseases. T he experience is mainly based on epidemiological studies (cohort studies and time-series studies). A limitation with both study designs is the exposure characterisation, which is usually based on data from a single monitoring site in the area, and assumed to be representative for all individuals in the area. A nother limitation is that most of the exposure information is on fine particles $\left(\mathrm{PM}_{2.5}\right)$, or the sum of fine and coarse particles $\left(P M_{10}\right)$, whereas the information on ultrafine particles is limited.

H uman non-cancer health effects from exposure to particles from wood smoke

The emission of particles from residential wood burning and their impact on human health has received much attention lately.

Several early studies (T able 5 ) have focused on the presence of a wood stove in the home as a risk factor. While these studies strongly suggest that there are adverse health impacts in form of more respiratory symptoms and diseases associated with wood smoke exposure, their crude exposure assessments preclude more specific conclusions.

In addition, a number of studies ( $T$ able 7 ) have reported associations of adverse health impacts in the airways with use of biomass fuels. All these studies are observational and very few have measured exposure directly, while a substantial proportion have not dealt with confounding. As a result, risk estimates are poorly quantified and may be biased.

A number of studies ( $T$ able 6 ) have evaluated adverse health effects from ambient air pollution in relation to residential wood combustion in communities where wood smoke was a major, although not the only, source of ambient air particulate. T he studies indicate a consistent relationship between $\mathrm{PM}_{1}, \mathrm{PM}_{2.5}$ and/or $\mathrm{PM}_{10}$ and increased respiratory and asthmatic symptoms, and decreased lung function. T he studies have mainly focused on children, but the few studies focusing on adults as well have shown similar results. T here are also indications from several of the studies that asthmatics are a particularly sensitive group. T he studies giving an indication of the doseresponse relationship are summarised in T able 8 (section 7.2.2.1). The relative risk $(R R)$ between an increase in ambient $P M_{10}$ with $10 \mu \mathrm{g} / \mathrm{m}^{3}$ and different health outcomes varied between 1.01 and 1.12. An RR for increased asthma hospital admissions of 1.15 and 1.04 has been reported for an increase in ambient $P M_{2.5}$ with 11 and $12 \mu \mathrm{g} / \mathrm{m}^{3}$, respectively. An RR for increased asthma symptoms in children of 1.17 has been reported for an increase in ambient $\mathrm{PM}_{1}$ with $10 \mu \mathrm{g} / \mathrm{m}^{3}$. 
O verall, these studies showed that an increased risk of experiencing adverse health effects in the respiratory tract from exposure to particles in wood smoke (RR 1.04-1.17) is associated with an increase in ambient PM (PM ${ }_{1}$, $P M_{2.5}$ and $P M_{10}$ ) of about $10 \mu \mathrm{g} / \mathrm{m}^{3}$. N one of the available studies have indicated a threshold concentration for effects. H owever, it should be noted that due to differences in the statistical analyses and presentation of the results in the various studies, it is difficult to compare the results from different studies.

Boman et al. (2003) compared the results from the five wood smoke studies in which residential wood combustion was mentioned as an important air pollution source with estimations for the association between PM and health effects in the general environment (Figure 3). All the included studies showed significant positive associations for respiratory symptoms evaluated. In comparison with the estimations concerning ambient PM and health effects in the general environment, the R R were even stronger in the studies in which residential wood combustion was considered a major $\mathrm{PM}$ source.

A very recently published review ( $N$ aeher et al. 2007), which is based on an extended list of references, confirms the overall picture presented by Bomann et al. (2003).

In conclusion, the available studies indicate that exposure to wood smoke PM is associated with the same kind of non-cancer health effects known from exposure to PM in general and that the health effects associated with PM in areas polluted with wood smoke are not weaker than elsewhere. However, the uncertainties about the actual contribution from wood smoke to ambient concentrations of PM preclude, for the time being, precise characterisations of specific dose-response relationships for wood smoke PM and whether differences exist compared to the known dose-response relationships from PM in general. T herefore, a more precise evaluation of the impact on human health of air pollution related to residential wood combustion is not possible for the time being.

Human carcinogenic effects from exposure to particles from wood smoke

T here is limited information regarding the human cancer risks associated with biomass air pollution, including wood smoke. T he $C$ hinese studies on an association between wood smoke exposure and lung cancer risk do not indicate an increased risk even after long-term exposure to very high levels of biomass smoke $\left(\mathrm{PM}_{10} 22 \mathrm{mg} / \mathrm{m}^{3}\right)$ from open-fire domestic cooking. T wo more recent case-control studies from M exico and Southern B razil are suggestive of a small increased risk of lung cancer due to long-term exposure to wood smoke from cooking; however, these studies are limited by the lack of exposure assessments. T he most recent case-control study found an increased risk for lung cancer among C anadian women in homes with wood stove or fireplace heating and with gas or wood stove cooking facilities.

In conclusion, the available studies do not provide a sufficient basis in order to evaluate whether there is an association between wood smoke exposure and increased risk of lung cancer. H owever, cohort studies on cancer risk associated with particles in the general environment have suggested an excess risk of lung cancer associated with long-term exposure to PM. K nown chemical carcinogens, e.g. PAH s, associated with the PM might be 
responsible for the excess risk of lung cancer; however, it can not be excluded that PM in itself is capable of causing lung cancer.

It should be noted that the International A gency for Research on C ancer (IARC 2008) has recently evaluated that indoor emissions from household combustion of biomass fuel (primarily wood) are probably carcinogenic to humans ( $G$ roup $2 A$ ).

Datafrom studies in experimental animals

M ost studies on adverse health effects of wood smoke particles in experimental animals have used relatively high exposure levels compared to the levels generally measured in the environment.

In one study, minor but significant changes in the airways of rats (mild chronic inflammation and squamous metaplasia in the larynx; alveolar macrophage hyperplasia and pigmentation, and slightly thickened alveolar septae) were observed following exposure (whole-body, 3 hours/day, 5 days/week for 4 or 12 weeks) to 1 or $10 \mathrm{mg} / \mathrm{m}^{3}$ wood smoke particles (size distribution of $63-74 \%$ in the $<1 \mu \mathrm{m}$ fraction and $26-37 \%$ in the $>1 \mu \mathrm{m}$ fraction).

A very recent study has summarised health effects of subchronic exposure to environmental levels of hardwood smoke in rats and mice exposed (wholebody, 6 hours/day, 7 days/week) for 1 week or 6 months) to dilutions of whole emissions based on particulate ( $30-1000 \mu \mathrm{g} / \mathrm{m}^{3}$ total PM , mass median aerodynamic diameter of approximately $0.3 \mu \mathrm{m}$ ). Exposure to these concentrations presented little to small hazard with respect to clinical signs, lung inflammation and cytotoxicity, blood chemistry, haematology, cardiac effects, and bacterial clearance, and carcinogenic potential. H owever, parallel studies demonstrated mild exposure effects on broncho-alveolar lavage parameters and in mouse and rats models of asthma. L ung carcinogenesis measured as either the percentage of young mice with tumours (incidence) or the number of tumours per tumour-bearing mouse (multiplicity) yielded no significant differences from the control group and there was no evidence of a progressive exposure-related trend.

\section{Risk ch ar acterisation}

In order to assess the health impacts from the wood smoke PM, the doseresponse relationship from the epidemiological studies on ambient PM in general (i.e., the relative risk $R R$ ) has been used as the available epidemiological studies indicate that wood smoke PM does not seem to be less harmful than ambient PM in general.

The health impact of PM from wood smoke emissions in D enmark has been assessed for mortality, and for hospital admissions for respiratory and cardiovascular diseases based on the known dose-response relationships for ambient PM in general as assessed from the available epidemiological studies as well as from the data from the few studies where wood smoke was indicated to be a major source.

T he increase in the R R for a health endpoint related to ambient PM in general is used to estimate the increase in R R for the specific health endpoint due to the contribution from wood smoke PM. T hen this R R is used to estimate the 
number of cases for this specific health endpoint, which is associated to wood smoke PM .

From the estimated increase of $6 \%(95 \% \mathrm{Cl}: 2-11 \%)$ in the mortality rate for an increase of $10 \mu \mathrm{g} / \mathrm{m}^{3}$ of $\mathrm{PM}_{2.5}$ as concluded by W HO (2005), the overall contribution of $0.6 \mu \mathrm{g} / \mathrm{m}^{3}$ of $P M_{2.5}$ from wood smoke to the annual population exposure is estimated to be associated with an increase in the mortality rate of $0.36 \%$ ( $95 \% \mathrm{Cl}: 0.12-0.66 \%$ ). T his increase in mortality rate corresponds to about 200 deaths each year (95\% Cl: 66-360). It should be noted, however, that the most recent studies by Jerret et al. (2005) and L aden et al. (2006) found a nearly 3 times higher increase in the mortality rate per $10 \mu \mathrm{g} / \mathrm{m}^{3}$ increase in $\mathrm{PM}_{2.5}$ than the dose-response used by W HO and thus, the use of the W HO estimate may result in an underestimation of the mortality rate.

From the estimated increase of 3.3\% in respiratory hospital admissions for an increase of $10 \mu \mathrm{g} / \mathrm{m}^{3}$ of $\mathrm{PM}_{2.5}$ from the Sheppard et al. (1999) study, the overall contribution of $0.6 \mu \mathrm{g} / \mathrm{m}^{3}$ of $\mathrm{PM}_{2.5}$ from wood smoke to the annual population exposure is estimated to be associated with an increase in respiratory hospital admissions of $0.2 \%$. T his increase in respiratory hospital admissions corresponds to about 156 cases each year. It should be noted, however, that using an estimate for increase in respiratory hospital admissions from a shortterm time-series study in relation to an annual increase in PM most probably will underestimate the actual health impact.

From the estimated increase of $14 \%$ for new cases of chronic bronchitis for an annual increase of $10 \mu \mathrm{g} / \mathrm{m}^{3}$ of $\mathrm{PM}_{2.5}$ as assessed by the European Commission (2005), the overall contribution of $0.6 \mu \mathrm{g} / \mathrm{m}^{3}$ of $\mathrm{PM}_{2.5}$ from wood smoke to the annual population exposure is estimated to be associated with an increase of $0.84 \%$ for new cases of chronic bronchitis. This corresponds to about 60 new cases of chronic bronchitis each year.

$\mathrm{N}$ o epidemiological data on wood smoke exposure in relation to cardiovascular diseases are available neither from time-series studies nor from cohort studies. H owever, the high increased risks for cardiovascular events (coronary heart disease, cerebro-vascular disease, myocardial infarction, coronary re-vascularisation, stroke) and cardiovascular mortality found in a very recent study by $\mathrm{M}$ iller et al. (2007) in a subgroup of women (above the age of 50 years and without previous cardiovascular disease) in relation to long-term particle exposure ( general ambient air PM ) indicate that even an annual increase of $0.6 \mu \mathrm{g} / \mathrm{m}^{3} \mathrm{PM}_{2.5}$ would have a significant health impact for the $D$ anish population with respect to cardiovascular events and mortality. H owever, due to the specific design of this study a general health impact assessment for the whole population cannot be made.

It should be remembered that this preliminary health impact assessment of woodsmoke PM is hampered by the limited exposure data available as well as by the absence of specific dose-response relationships for the selected health impacts due to long-term exposure to wood smoke PM. It should also be noted that the approach taken to assess the selected health impacts for wood smoke PM is in general considered to underestimate the health impacts as the dose-response relationship for mortality most likely is underestimated. 
$M$ ore information is needed for a more precise health impact assessment of wood smoke PM in D enmark, particularly in relation to assess the exposure to wood smoke PM in the general population as well as to assess the effects from long-term exposure of wood smoke PM on morbidity and mortality including a characterisation of the specific dose-response relationships for the various adverse health effects related to wood smoke PM exposure.

It might thus be recommended to conduct one or more studies in a selected residential area with many wood stoves aiming at 1 ) assessing the exposure to wood smoke PM including measurements of chemical markers for wood smoke in order to evaluate the contribution of wood smoke PM to the ambient general PM , 2) characterising wood smoke PM as well as wood smoke composition, 3) investigating indoor exposure to wood smoke, and 4) investigating the relationship between exposure to wood smoke PM and the health outcomes including a characterisation of the specific dose-response relationships for the various adverse health effects related to wood smoke PM exposure.

In addition there is still a need for further experimental studies aiming at understanding the effects and underlying mechanisms of wood smoke exposure in order to evaluate the implication in relation to human health risks as well as investigating chemical and physical particle properties and health effects in relation to the different phases of the combustion cycle and type of combustion device including modern stoves. 


\section{Sammenfatning}

I D anmark er privat opvarmning med træ steget i løbet af de seneste år, og det anslås, at der i 2005 var ca. 551.000 brændeovne og ca. 48.000 brændekedler. D ette betyder umiddelbart, at befolkningen i øget grad vil blive udsat for partikler fra brænderøg. $\mathrm{N}$ yere målinger af luftens indhold af partikler $\mathrm{i}$ vinterhalvåret har vist klart forhøjede partikelniveauer i områder med mange brændeovne som for eksempel i villakvarterer. Som følge af brænderøgspartiklernes ringe partikelstørrelse vil stort set hele partikelmængden kunne måles ved $\mathrm{PM}_{2,5}$-målinger, som omfatter måling af fine partikler, dvs. partikler med en diameter under 2,5 $\mu \mathrm{m}$. D et er vurderet, at der i D anmark årligt udsendes omkring 17.665 tons partikler i form af $\mathrm{PM}_{2.5}$ som følge af fyring med træi boligområder. D erfor har der i de senere år været en øget opmærksomhed rettet mod de mulige sundhedsskadelige effekter og helbredskonsekvenser, der kan være forbundet med den stigende udsættelse for partikler fra brænderøg.

Bef ol kningens udsæt tel se for partikler fra brænder øg

På nuværende tidspunkt er der kun begrænset viden vedrørende den danske befolknings samlede udsættelse for partikler fra brænderøg.

I vinteren 2002 og 2003-2004 blev der målt i en seks ugers periode i et dansk parcelhusområde uden fjernvarme og med mange brændeovne.

Partikelniveauet ( målt som $\mathrm{PM}_{2.5}$ ) i området var sammenligneligt med partikelniveauet målt på fortovet ved en meget stærkt trafikeret vej. D et gennemsnitlige partikelbidrag fra brændeovnene blev målt til ca. $4 \mu \mathrm{g} / \mathrm{m}^{3}$. I et andet beboelsesområde med naturgas som hovedopvarmningskilde og brændeovne som den sekundære opvarmningskilde var partikelniveauet $\mathrm{i}$ luften forøget med ca. $1 \mu \mathrm{g} / \mathrm{m}^{3}$ i forhold til baggrundsniveauet. M ålingerne blev foretaget i en 4-ugers vinterperiode.

På baggrund af disse to målekampagner vurderes et årsvægtet gennemsnit på ca. $1 \mu \mathrm{g} / \mathrm{m}^{3}$ at være det bedste skøn for den samlede befolknings maksimale merbelastning med partikler fra brændeovne.

M odelberegninger baseret på den totale partikelemission fra brændeovne og betydningen af dette for det gennemsnitlige $\mathrm{PM}_{2.5}$-niveau over $\mathrm{D}$ anmark har vist, at befolkningens gennemsnitlige årlige partikeludsættelse herved forøges med ca. $0,2 \mu \mathrm{g} / \mathrm{m}^{3}$. På baggrund heraf vurderes et årsvægtet gennemsnit på ca. $0,2 \mu \mathrm{g} / \mathrm{m}^{3}$ at være det bedste skøn for den samlede befolknings minimale merbelastning med partikler fra brændeovne.

Sammenfattende konkluderes det, at partikelbidraget fra brænderøg kan medføre en forøgelse af befolkningens gennemsnitlige årlige $\mathrm{PM}_{2.5}$ på mellem 0,2 og $1 \mu \mathrm{g} / \mathrm{m}^{3}$, hvor et bidrag på 0,6 $\mu \mathrm{g} / \mathrm{m}^{3}$ må anses at være det bedste skøn for den samlede befolknings merbelastning med partikler fra brændeovne.

Partikler på omkring $1 \mu \mathrm{m}$ og derunder kan let trænge ind i boligerne, især hvis luften ikke filtreres undervejs. En nyere svensk undersøgelse har vist, at partikler i udeluften kan bidrage betydeligt til partikelniveauet inde i boligerne, 
hvor niveauet af partikler, der trængte ind i boligen, udgjorde mellem 50 og $80 \%$ i forhold til niveauet af partikler i udeluften.

Hel bredseff ekter, data fra bef ol kningsundersøgel ser

Partikler generelt

Sammenhængen mellem forøgede niveauer af partikler i udeluften og sundhedsskadelige effekter i befolkningen er veletableret. D er er især set øget forekomst af hjertekarsygdomme og luftvejslidelser, primært blandt ældre og personer der i forvejen lider af luftvejs- og/eller hjertekarsygdomme. D enne viden er opnået fra befolkningsundersøgelser udført enten som kohorte undersøgelser, hvor en afgrænset og veldefineret befolkningsgruppes helbred og udsættelse for partikler følges gennem længere tid, eller som tidsserie undersøgelser, hvor betydningen af kortvarige dag til dag variationer $\mathrm{i}$ partikelniveauet undersøges i forhold til sygelighed og dødelighed i et givent område. Fæles for de to former for undersøgelser er, at der mangler en mere præcis karakterisering af hvilke partikelniveauer, de enkelte personer har været udsat for, da udsættelsen for hele befolkningsgruppen ofte beskrives ved en enkelt eller få målestationers målinger. En anden begrænsning er, at eksponeringen ofte er angivet som fine partikler $\left(P M_{2,5}\right)$ eller summen af fine og grove partikler $\left(P M_{10}\right)$, hvorimod informationer om de mindre, ultrafine partikler $\left(\mathrm{PM}_{0,1}\right)$ ofte savnes.

\section{Sundhedsskadelige effekter af partikler fra brænderøg}

Som nævnt har der i de senere år været en øget opmærksomhed rettet mod de mulige sundhedsskadelige effekter og helbredskonsekvenser, der kan være forbundet med den stigende udsættelse for partikler fra brænderøg.

En række tidlige undersøgelser (angivet i tabel 5) har belyst tilstedeværelsen af en brændeovn i hjemmet som en risikofaktor. Selvom disse undersøgelser peger på, at der er sundhedsskadelige effekter i form af luftvejssymptomer og luftvejslidelser, er det på grund af manglende eksponeringsvurderinger i de pågældende undersøgelser ikke muligt at drage mere præcise konklusioner.

Endvidere har flere undersøgelser (angivet $\mathrm{i}$ tabel 7) peget på sammenhænge mellem luftvejslidelser og anvendelsen af biomasse som varmekilde. Alle disse undersøgelser er observations undersøgelser, der har den begrænsning, at der ikke i tilstrækkeligt omfang er taget højde for andre betydende faktorer, samtidig med at kun meget få af undersøgelserne angiver mål for eksponeringen. R isikoestimaterne er derfor usikre, især da de kan være påvirket af andre faktorer end biomassen.

Endelig har man i en række undersøgelser (angivet i tabel 6) sammenholdt de sundhedsskadelige effekter forårsaget af partikler i udeluften i områder, hvor partikler fra brænderøg var en betydelig kilde til det totale partikelniveau i udeluften. $D$ isse undersøgelser peger samstemmende på en sammenhæeng mellem partikelniveauet $\left(\mathrm{PM}_{1}, \mathrm{PM}_{2,5}\right.$ og/eller $\left.\mathrm{PM}_{10}\right)$ i udeluften og en forøget forekomst af luftvejs- og astmasymptomer herunder nedsat lungefunktion hos befolkningen i de pågældende områder. U ndersøgelserne har primært fokuseret på børn, men de få undersøgelser, hvor voksne er involveret, viser tilsvarende resultater. Flere af disse undersøgelser peger også på, at astmatikere er en særlig sårbar gruppe i forhold til øget forekomst af partikler i udeluften. D osis-respons sammenhænge kan vurderes i en række af disse 
undersøgelser (angivet $\mathrm{i}$ tabel 8). D en relative risiko ( $R \mathrm{R})$ for de forskellige helbredseffekter udtrykt for en stigning i PM ${ }_{10}$ i udeluften på $10 \mu \mathrm{g} / \mathrm{m}^{3}$ varierede mellem 1,01 og 1,12. I de undersøgelser, hvor PM ${ }_{2,5}$ blev målt, fandt man ved forøgede niveauer på $11 \mathrm{og} 12 \mu \mathrm{g} / \mathrm{m}^{3}$ i udeluften en RR på 1,15 henholdsvis 1,04 for hospitalsindlæggelser forårsaget af astma. I en undersøgelse, hvor man målte $\mathrm{PM}_{1}$, fandt man ved et forøget niveau på 10 $\mu \mathrm{g} / \mathrm{m}^{3}$ en R R på 1,17 for stigning i astmasymptomer hos børn.

Samlet viser disse undersøgelser en forøget risiko for sundhedsskadelige effekter i luftvejene hos personer, der er udsat for partikler fra brænderøg med en relativ risiko på 1,04-1,17 ved en stigning på omkring $10 \mu \mathrm{g} / \mathrm{m}^{3} \mathrm{PM}\left(\mathrm{PM}_{10}\right.$ $\mathrm{PM}_{2.5}$ eller $\mathrm{PM}_{1}$ ) i udeluften. Ingen af de anførte undersøgelser har kunnet identificere et nedre partikelniveau uden effekt (tærskel). D er skal dog gøres opmærksom på, at på grund af forskelle i forsøgsdesign, herunder de statistiske analyser, samt måden hvorpå data præenteres i de forskellige undersøgelser, er det vanskeligt at foretage en direkte sammenligning mellem de kvantitative sammenhæenge undersøgelserne imellem.

En svensk undersøgelse (Boman et al. 2003) sammenlignede dosis-respons sammenhæenge fra de fem undersøgelser, hvor brænderøg var anført som en betydelig kilde til partikelniveauet i udeluften, med de dosis-respons sammenhæange der kendes fra undersøgelser omhandlende partikler i udeluften generelt ( figur 3). Sammenlignet med risikoestimaterne for partikler i udeluften generelt viste risikoestimaterne i undersøgelserne med brænderøg som en betydelig kilde til partikelniveauet i udeluften generelt en større effekt, dvs. en større effekt pr. ug/m $\mathrm{m}^{3}$. D enne vurdering understøttes også af den meget omfattende og senest opdaterede oversigtsartikel af $\mathrm{N}$ aeher et al. (2007).

Sammenfattende kan det ud fra de ovenstående undersøgelser konkluderes, at partikler fra brænderøg må forventes at kunne medføre de samme typer sundhedsskadelige effekter, som er kendt fra undersøgelserne af partikler i udeluften generelt, og at effekterne ikke tyder på at være mindre udtalte, når der er tale om partikler fra brænderøg.

D er skal dog gøres opmærksom på, at på grund af mangel på præcis viden om andelen af partikler fra brænderøg i det totale partikelniveau i udeluften i de ovenstående undersøgelser er det ikke muligt at vurdere de præcise dosisrespons sammenhænge for effekterne forårsaget af partiklerne fra brænderøg alene, såvel som mere præcist at vurdere forskelle i dosis-respons sammenhænge i forhold til partikler i udeluften generelt. D ette betyder, at det i øjeblikket ikke er muligt at foretage en meget præcis vurdering af brænderøgspartiklernes indflydelse på befolkningssundheden.

Kræftfremkaldende effekter af partikler fra brænderøg

D er er begrænset information mht. en eventual krætfremkaldende effekt relateret til afbrænding af biomasse herunder brænderøg. $\mathrm{K}$ inesiske undersøgelser har ikke fundet nogen sammenhæng mellem udsæitelse for brænderøg og lungekræft selv efter lang tids udsættelse for forholdsvise høje partikelniveauer ( $22 \mu \mathrm{g} / \mathrm{m}^{3}$ som $\mathrm{PM}_{10}$ ) fra åbne køkkenildsteder. To nyere undersøgelser fra $M$ exico og Brasilien peger på en lille forøget risiko for lungekræt i forbindelse med lang tids udsættelse for brænderøg fra køkkenildsteder. R esultaterne af disse undersøgelser begrænses dog af mangel på konkret viden om eksponeringen. $\mathrm{D}$ en seneste undersøgelse fra $\mathrm{C}$ anada 
viste en øget risiko for lungekræft blandt kvinder i hjem med træfyring som boligopvarming og med gas- eller træopvarmet komfur i køkkenet.

U d fra dette datagrundlag alene er der således ikke et tilstrækkeligt grundlag til at foretage en samlet vurdering af, hvorvidt der er en sammenhæeng mellem partikler fra brænderøg og øget risiko for lungekræft. F ra de store kohorte undersøgelser vedrørende udeluft generelt er det imidlertid dokumenteret, at der er en sammenhæng mellem udsættelse for partikler og øget risiko for lungekræt. K endte kræftfremkaldende stoffer som for eksempel PAH (en forbrændingskomponent bundet til partiklerne) kan være ansvarlig for denne sammenhæng, men det kan ikke udelukkes at partikler i sig selv (dvs. uden forbrændingskomponenter) også kan fremkalde lungekræft.

D et skal i denne sammenhæeng nævnes, at det internationale kræftforskningscenter, IARC for nylig (2008) har vurderet indendørs biomasse emission ( primært træafbrænding) som sandsynligt krætfremkaldende over for mennesker (IARC gruppe 2A).

\section{Viden fra undersøgel ser med forsøgsdyr}

D e fleste undersøgelser med forsøgsdyr har anvendt relativt høje partikelniveauer fra brænderøg sammenlignet med de generelle partikelnivauer i udeluft.

I en undersøgelse har man fundet lettere, men statistisk signifikante forandringer i luftvejene (mild grad af kronisk betændelsestilstand og forandringer i overflade cellelaget i svælget, ophobning af makrofager med indhold af partikler i alveolerne (lungernes yderste forgreninger), samt en lettere fortykkelse af vævet ved overgangen til alveolerne) hos rotter, der havde været udsat for partikler fra brænderøg i niveauer på 1 og $10 \mathrm{mg} / \mathrm{m}^{3} 3$ timer dagligt, 5 dage om ugen i 4 eller 12 uger (63-74\% af partiklerne mindre end $1 \mu \mathrm{m})$.

I en nyere undersøgelse udsatte man både rotter og mus for forskellige fortyndinger af brænderøg ( røg fra hårdt træ) 6 timer dagligt i en uge henholdsvis et halvt år. L aveste og højeste eksponeringsniveau var på 30 henholdsvis $1000 \mu \mathrm{g} / \mathrm{m}^{3}$ målt som partikler med en gennemsnitlig aerodynamisk diameter på 0,3 $\mu \mathrm{m}$. I undersøgelsen, hvor man undersøgte for en række effekt parametre (klinisk tilstand, betændelse i lungerne, tegn på toksicitet i celler fra lungerne, klinisk-kemiske parametre i blodet, effekter på hjertet, evnen til at fjerne bakterier fra lungerne) fandt man kun meget lette effekter. Parallelle undersøgelser har ligeledes vist tegn på lettere effekter på dyrenes lunger ud fra analyser af væske fra lungerne. I mus, der yderligere blev undersøgt for krætfremkaldende effekt i lungerne, var der ikke nogen øget forekomst i forhold til en kontrolgruppe, hverken i andelen af mus med lungekræt eller i antallet af tumorer hos de mus, der udviklede lungekræft.

\section{Risiko karakterisering}

For at vurdere helbredskonsekvenserne for den danske befolkning som følge af udsættelse for partikler fra brænderøg anvendes dels de veletablerede dosisrespons sammenhæange, der er fundet for partikler generelt i udeluften i de store befolkningsundersøgelser og dels data fra de forholdsvis få befolkningsundersøgelser, hvor partikler fra brænderøg specifikt er fremført 
som en betydelig kilde. Sidstnævnte dækker dog kun forholdsvis få effektområder, men anvendelse af dosis-respons sammenhænge for partikler generelt på øvrige effektområder anses for at være en rimelig fremgangsmåde, da de forholdsvis få undersøgelser omhandlende partikler fra brænderøg tyder på, at disse partikler ikke er mindre sundhedsskadelige end partikler generelt. WHO peger da også på, at det især er udeluftens indhold af forbrændingspartikler (bl.a. fra biomasse), der er væsentlig for, at de sundhedsskadelige effekter opstår.

H elbredskonsekvenserne for den danske befolkning som følge af udsættelse for partikler fra brænderøg er vurderet for følgende parametre: antal dødsfald, hospitalsindlæggelser som følge af luftvejslidelser samt hjertekarsygdomme. V urderingerne er baseret på, at brændeovne herhjemme medfører en forøgelse af det årlige gennemsnitlige partikelniveau $\left(\mathrm{PM}_{2,5}\right)$ på $0,6 \mu \mathrm{g} / \mathrm{m}^{3}$. D en relative risiko $(R R)$, der er fundet i undersøgelserne for de enkelte parametre, anvendes til at beregne antallet af tilfælde, som kan tilskrives det ekstra bidrag til partikelniveauet i udeluften, som brændeovnene vurderes at bidrage med herhjemme.

W HO (2005) har vurderet, at den samlede dødelighed i befolkningen stiger med 6\% (95\% konfidensinterval: 2-11\%) for hver gang, det årlige gennemsnitsniveau af $P M_{2,5}$ stiger med $10 \mu \mathrm{g} / \mathrm{m}^{3}$. Baseret på denne dosisrespons sammenhæng vil et årligt bidrag på $0,6 \mu \mathrm{gg} / \mathrm{m}^{3} \mathrm{PM}{ }_{2,5}$ fra brænderøg være forbundet med en stigning i dødeligheden på 0,36\% (95\% konfidensinterval: $0,12-0,66 \%)$. D ette svarer til, at partikler fra brænderøg medfører ca. 200 (95\% konfidensinterval: 66-360) ekstra dødsfald i D anmark pr. år.

D et skal imidlertid bemærkes, at nyere befolkningsundersøgelser udført af L aden et al. (2006) og Jerret et al. (2005) har fundet 2-3 gange større effekt af $\mathrm{PM}_{2,5}$ i forhold til den dosis-respons sammenhæeng, der er vurderet af W H O.

I en undersøgelse af Sheppard et al. (1999) fandt man en stigning i hospitalsindlæggelser som følge af luftvejslidelser på 3,3\% pr. $10 \mu \mathrm{g} / \mathrm{m}^{3}$ stigning i det daglige niveau af $\mathrm{PM}_{2.5}$ I denne undersøgelse var røg fra brændeovne en sælig betydende kilde. Baseret på denne dosis-respons sammenhæng vil et årligt bidrag på $0,6 \mu \mathrm{g} / \mathrm{m}^{3} \mathrm{PM}_{2,5}$ fra brænderøg være forbundet med en stigning i hospitalsindlæggelser som følge af luftvejslidelser på 0,2\%. D ette svarer til, at partikler fra brænderøg medfører ca. 156 ekstra hospitalsindlæggelser som følge af luftvejslidelser i D anmark pr. år.

D er skal her gøres opmærksom på, at man ved at anvende en dosis-respons sammenhæng fra kort tids (daglig) eksponering på det årlige gennemsnitniveau for $\mathrm{PM}_{2,5}$ mest sandsynligt vil underestimere helbredskonsekvenserne.

EU Kommissionen (2005) har angivet en stigning på 14\% i nye tilfælde af kronisk bronchitis som følge af en $10 \mu \mathrm{g} / \mathrm{m}^{3}$ stigning i det årlige gennemsnitsniveau af $P M_{2,5}$. Baseret på denne dosis-respons sammenhæng vil et årligt bidrag på 0,6 $\mathrm{\mu g} / \mathrm{m}^{2,3} \mathrm{PM}_{2,5}$ fra brænderøg være forbundet med en stigning af nye tilfælde med kronisk bronchitis på 0,84\%. D ette svarer til, at partikler fra brænderøg medfører ca. 60 ekstra tilfælde af kronisk bronchitis i D anmark pr. år.

Der foreligger ingen befolkningsundersøgelser vedrørende hjertekarsygdomme relateret til udsættelse for partikler fra brænderøg. En ny undersøgelse af $M$ iller et al. (2007) fandt imidlertid en øget risiko på $24 \%$ for udvikling af 
hjertekarsygdomme og på 76\% for dødsfald i tilknytning hertil ved en forøgelse af det årlige PM ${ }_{2.5}$ niveau på $10 \mu \mathrm{g} / \mathrm{m}^{3}$. D et skal imidlertid bemærkes, at denne undersøgelse udelukkende inkluderede en gruppe kvinder over 50 år, så det er derfor vanskeligt herudfra at vurdere betydningen for den samlede befolkning. D og indikerer den forholdsvis høje øgede risiko for udvikling af hjertekarsygdomme og dødsfald relateret hertil observeret i M iller et al. (2007) studiet, at selv et årligt bidrag på 0,6 $\mu \mathrm{g} / \mathrm{m}^{3} \mathrm{PM}_{2,5}$ fra brænderøg vil kunne have en mærkbar indflydelse på antallet af hjertekarsygdomme og dødsfald relateret hertil.

D et skal bemærkes, at denne indledende vurdering af helbredskonsekvenserne for den danske befolkning som følge af udsættelse for partikler fra brændeovne er begrænset af de meget sparsomme data vedrørende befolkningens eksponering samt af de forholdsvis få undersøgelser, der specifikt har vurderet helbredseffekterne af partikler fra brænderøg. D en anvendte fremgangsmåde til vurdering af helbredskonsekvenserne anses dog for at undervurdere helbredseffekterne, specielt mht. dødelighed, da nyere undersøgelser peger på en større effekt end den dosis-respons sammenhæng, der er vurderet af WHO (2005).

\section{An bef al inger}

D er er generelt behov for mere viden for at kunne foretage en mere præcis vurdering af helbredskonsekvenserne for den danske befolkning som følge af udsættelse for partikler fra brænderøg. I sær er det vigtigt at få en bedre eksponeringsvurdering, dvs. en bedre beskrivelse af befolkningens udsætelse for partikler fra brænderøg, samt en bedre viden om de kritiske sundhedsskadelige effekter af disse partikler, inklusive en bedre viden om dosis-respons sammenhænge for disse effekter.

D et anbefales derfor, at der udføres en eller flere undersøgelser i et udvalgt boligområde med mange brændeovne med fokus på 1) vurdering af befolkningens eksponering for partikler fra brænderøg inklusive målinger af kemiske markører for brænderøg for derved at kunne beregne partikelbidraget fra brænderøg til det totale partikelniveau i udeluften, 2) karakterisering af partiklerne i brænderøg såvel som sammensæningen af brænderøg, 3) undersøgelse af eksponering for brænderøg inden døre, og 4) undersøgelse af sammenhængen mellem eksponering for partikler fra brænderøg og helbredseffekter inklusive en beskrivelse af dosis-respons sammenhængen for disse effekter.

H erudover er der yderligere et behov for at foretage eksperimentelle undersøgelser med fokus på dels en klarlægning af de sundhedsskadelige effekter forårsaget af partikler fra brænderøg og de bagvedliggende mekanismer for herved bedre at kunne forstå og udpege de helbredsmæssige konsekvenser for mennesker dels at undersøge betydningen af de forskellige faser i forbrændingen samt typen af forbrændingsanordninger, inklusive moderne brændeovne, for de fysisk-kemiske partikelegenskaber såvel som helbredseffekter. 


\section{Introduction}

T he combustion of biomasses is the oldest and, overall, most widespread energy source used in a variety of applications for heat and power production, as well as for cooking. T he everyday life for a majority of the people in the world is dependent on fuels like wood, animal dung, and crop residues, as well as coal. H owever, according to Boman et al. (2003), only a small fraction (about $11 \%$ ) of the total global energy consumption is based on biomass fuels or other combustible renewable material and waste. An increasing interest in sustainable energy production has awakened globally, and the potential for an increased use of biomass fuels is significant.

C ombustion processes in general are major anthropogenic sources of many of the classical air pollutants such as carbon monoxide, nitrogen oxides, sulphur dioxides, and particulate matter, which have traditionally been associated with different adverse health effects. Residential wood combustion is often considered a major source of ambient local air pollutants, especially for particulate matter. Besides the major combustion products, carbon dioxide and water, wood smoke mainly consists of a complex mixture of particulate matter, inorganic gases, volatile organic hydrocarbons (VOC), and polycyclic aromatic compounds (PAC).

G enerally, residential wood appliances are relatively old, and, compared with modern wood and pellet technology, the combustion conditions are poorly optimised. This situation often results in considerable emissions of incomplete combustion products. For example, in the U nited States, it has been estimated that up to $90 \%$ of the ambient wintertime $\mathrm{PM}_{2.5}$ (mass of particles with an aerodynamic diameter of $\leq 2.5 \mu \mathrm{m}$ ) derive from residential wood combustion (Boman et al. 2003). In addition to the ambient exposure to wood smoke, exposure can also occur indoor as a result of direct release from heating devices or the infiltration of outdoor air pollution.

T here has been a relatively extensive amount of work done concerning the adverse health effects of both individual gaseous combustion by-products (e.g. carbon monoxide, nitrogen oxides, and sulphur dioxides) as well as particulate air pollution. The adverse health effects of particulate air pollution are well documented and the impact on the respiratory function has been demonstrated in many studies. T he existing knowledge is mainly related to general particulate air pollution or particles from traffic, determined as $\mathrm{PM}_{10}$ or $\mathrm{PM}_{2.5}$ and data on contributions from various sources and their individual health effects are limited.

F ewer studies have dealt with the adverse health effects of exposure to wood smoke. Since the emissions from residential wood combustion include a complex mixture of the aforementioned pollution components, it can be assumed that exposure to wood smoke is potentially harmful to human health. T oday, the focus concerning emissions from residential wood combustion and its implications for air quality and human health is mainly on particulate matter. 
T he number of residential wood burning devices has increased dramatically in $D$ enmark during the last decades. T his has resulted in an increased exposure of the general $D$ anish population to pollutants associated with residential wood smoke. $\mathrm{N}$ ew D anish monitoring results have shown that wood stoves can cause particle levels in residential areas that are comparable to levels at major roads. T herefore, there is an increasing concern that adverse human health effects might be associated with the increased exposure to residential wood smoke.

T his project has been set up in order to review the scientific literature concerning adverse health effects of pollutants associated with residential wood smoke with the main focus on particulate matter and to quantify and evaluate, if possible, the impact on human health of the increased exposure to particles in residential wood smoke.

T he report starts off with a general description of wood smoke and includes a physico-chemical characterisation of particles in wood smoke as well as in the general environment in order to evaluate whether particles in wood smoke are different from particles in the general environment (section 2).

$T$ his is followed by a summary of the available information of human exposure to particles in wood smoke with the main focus on the D anish studies and an exposure assessment is carried out for $D$ anish conditions (section 3).

Particle deposition in the respiratory tract and clearance are addressed in section 4.

T he available human and animal data on potential adverse health effects of exposure to particles from residential wood smoke (hazard assessment) are reviewed in section 5 and 6 , respectively. In addition, a brief summary of adverse health effects associated with particles in the general environment is included in order to evaluate whether the adverse health effects of particles in residential wood smoke are more or less worse than those of particles in the general environment.

Finally, based on the exposure and hazard assessments, a risk characterisation is carried out for $D$ anish conditions, if possible, i.e. if sufficient data on exposure and effects are available. In addition, the gaps of knowledge in the available data in order to perform a more refined risk characterisation are discussed. 


\section{Wood smoke, characterisation}

W ood smoke consists of, besides the major combustion products carbon dioxide and water, a complex mixture of compounds, including particulate matter, inorganic gases (e.g. carbon monoxide, nitrogen oxides, sulphur dioxides), volatile organic hydrocarbons (VOC), and polycyclic aromatic compounds (PAC). Particulate matter is itself a complex mixture and can be fractionated as inorganic ash material, soot, and condensed organic material.

In addition to temporal and seasonal variations, the physico-chemical characteristics of particulate matter as well as the associated adverse health effects exhibit large regional differences, even when the particles are from the same type of source. Such variations will complicate an evaluation of the association between exposure to particulate matter and adverse health effects. T he most important determinants of the toxicity of particles are the particle size and the chemical composition. These aspects will be addressed in the following sections.

\subsection{Particle size distribution}

T he particle size is believed to be an important parameter in relation to health effects. T he particle size can also reveal the origin / sources and the history of the particles. Furthermore, the particle size determines the atmospheric lifetime. (Palmgren et al. 2003).

T he particles size distribution is traditionally described as appearing in three modes according to the aerodynamic diameter of the particles: Coarse particles $(2.5-10 \mu \mathrm{m})$, fine particles $(0.1-2.5 \mu \mathrm{m})$, and ultrafine particles $(<0.1 \mu \mathrm{m})$. T he particle fractions most often used in epidemiological studies are $\mathrm{PM}_{10}$ and $\mathrm{PM}_{2.5}$, referring to the mass of particles with an aerodynamic diameter $\leq 10$ and $2.5 \mu \mathrm{m}$, respectively. (T rafikministeriet 2003, Palmgren et al. 2003). Figure 1 shows the particle size distribution in urban air.

In urban areas, the coarse mode particles are typically formed mechanically by abrasion of road material, tyres and brake linings, dust raised by wind, and traffic turbulence etc. $\mathrm{N}$ atural sources are soil dust and sea spray (sea salt). $T$ heir atmospheric lifetime is short (minutes to hours). Coarse particles contain inorganic ions (for example calcium, aluminium, silicon, magnesium and iron) and components with biological activity, e.g. allergens in pollen and toxins in mould spores. (Palmgren et al. 2003, T rafikministeriet 2003).

F ine mode particles are typically formed by atmospheric chemical/physical processes during long-range transport (e.g., sulphur dioxide and nitrogen oxides are transformed into sulphate and nitrate - secondary particles), or by other relatively slow processes in the atmosphere. (Palmgren et al. 2003). T he fine particles are therefore commonly aged particles and transported over long distances. T he main sources of the primary emissions of $\mathrm{PM}_{2.5}$ are vehicle exhausts, fossil fuel combustion (especially coal and wood heating), industrial processes, other biomass burning, and fugitive dust. T he main emissions of precursors for secondary $\mathrm{PM}_{2.5}$ formation are nitrogen oxides, sulphur 
dioxide, ammonia, and volatile organic hydrocarbons from different sources (Schlesinger \& C assee 2003). Fine particles contain especially elemental carbon and different metals, as well as organic compounds. In the PM ${ }_{2.5}$ fraction, fine particles (0.1-2.5 $\mu \mathrm{m})$ account for the largest mass, but the largest numbers are ultrafine particles (over $90 \%$ ), and the largest surface area per mass is in the accumulation mode fraction (0.1-1 $\mu \mathrm{m})$.

U Itrafine particles are primarily formed from gases by nucleation in air, and their atmospheric lifetime is short. U Itrafine particles are fuel or oil in the form of aerosols or solid elemental and organic carbon (soot) as well as heavy metals. The predominant source of ultrafine particles is traffic, particularly diesel engines, and these particles are therefore dominating in heavily trafficked areas. In general, there is limited information on the concentrations of ultrafine particles in ambient air because they have not been monitored comprehensively (T rafikministeriet 2003, Palmgren et al. 2003).

Figure 1. The particl e size distribution in urban air. From Trafikminister iet (2003).

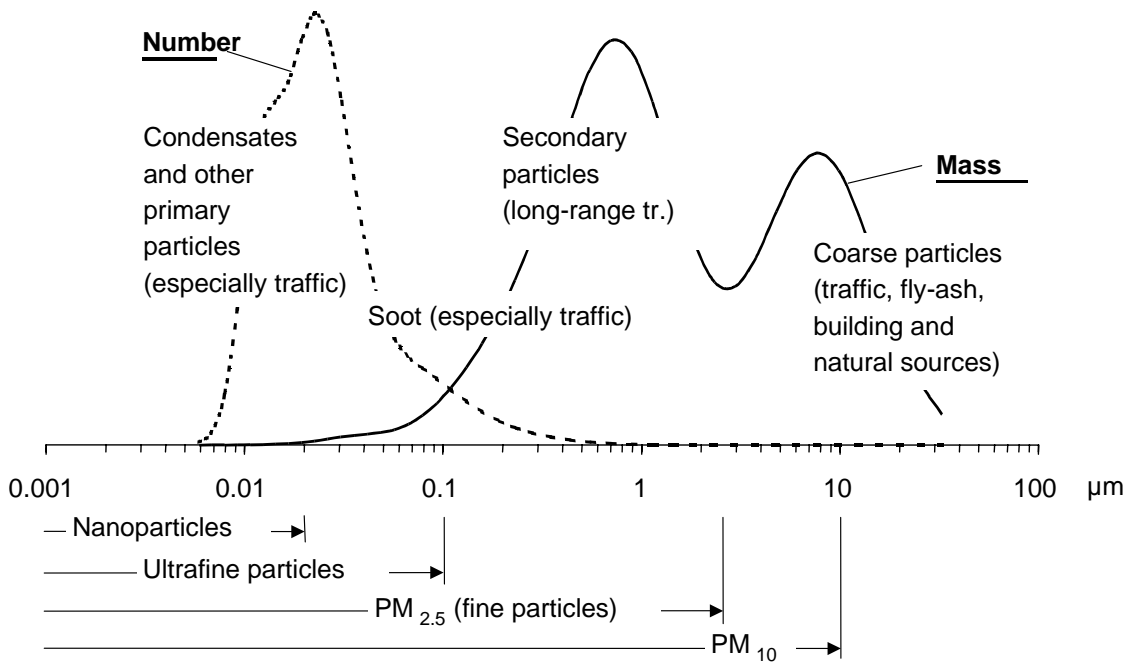

T he particle size varies strongly during the different phases of the wood combustion process. T he emissions are largest during the start-up phase when the particle size is in the range $60-70 \mathrm{~nm}$. D uring the intermediate and smouldering phases, the emissions decrease and the particle size distribution has two modes, one in the $20-30 \mathrm{~nm}$ range and another in the $100-200 \mathrm{~nm}$ range. $M$ easurements in a neighbourhood dominated by wood combustion emissions showed a particle size distribution composed of all three combustion phases, with particles from the start-up phase as dominating. It is likely that particles from different phases and size modes have a somewhat different chemical composition. (F orsberg et al. 2005).

Boman et al. (2004) have studied the emission of fuel pellets, a new biomass fuel. $T$ he emitted particles were mainly found in the fine $(<1 \mu \mathrm{m})$ mode with 
mass median aerodynamic diameters of $0.20-0.39 \mu \mathrm{m}$ and an average $\mathrm{PM}_{1}$ of $89.5 \% \pm 7.4 \%$ of total PM .

K ocbach et al. (2006) found a small difference in the particle diameter between primary carbon particles from vehicle exhaust and residential wood smoke. A mean diameter of $31 \pm 7 \mathrm{~nm}$ was found for primary carbon particles of wood smoke sampled from a single-stage combustion stove compared to a mean diameter of $24 \pm 6 \mathrm{~nm}$ for carbon particles sampled from a road tunnel.

\subsection{Chemical characterisation of wood smoke}

W ood consists of cellulose (50-70\%), lignin (about 30\%), and small amounts of resinous materials and inorganic salts. In wood, cellulose compounds form a supporting mesh that is reinforced by lignin polymers. T ogether these compounds form the rigid wood structure. U pon heating, these structures break apart producing a large variety of smaller molecules including methoxy phenols, methoxy benzenes, phenols, catechols, benzene, and alkyl benzenes. $\mathrm{N}$ on-wood biomass does not contain lignin and therefore the methoxy phenols and methoxy benzenes are unique tracers of wood smoke combustion. Conifers (softwoods) produce large amounts of resin acids while deciduous (hardwoods) trees do not. Combustion of hardwoods produces more ash and therefore more trace elements than softwoods. A pproximately $5-20 \%$ of wood smoke particulate mass is elemental carbon, while the composition of the organic carbon fraction varies with the specific biomass fuel being burned and with the combustion conditions. Potassium is the trace element found at highest concentrations in wood smoke and has often been used as a wood smoke tracer. T able 1 summarises the chemical composition of wood smoke. ( $L$ arson \& K oenig 1994).

In a detailed analysis of organic wood smoke aerosol, nearly 200 distinct organic compounds were measured in wood smoke, many of them derivatives of wood polymers and resins (Rogge et al. 1998).

Table 1. Chemical composition of wood smoke. From Lar son and Koenig (1994).

\begin{tabular}{|l|l|}
\hline Species & $\mathrm{g} / \mathrm{kg}$ wood \\
\hline Carbon monoxide & $80-370$ \\
\hline M ethane & $14-25$ \\
\hline VOCs $\left(\mathrm{C}_{2}-\mathrm{C}_{7}\right)$ & $7-27$ \\
\hline $\begin{array}{l}\text { Aldehydes (formaldehyde, acrolein, propionaldehyde, butyraldehyde, acetaldehyde, } \\
\text { furfural }\end{array}$ & $0.6-5.4$ \\
\hline Substituted furans & $0.2-16$ \\
\hline Benzene & $0.6-4.0$ \\
\hline Alkylbenzenes & $1-6$ \\
\hline Acetic acid & $1.8-2.4$ \\
\hline Nitrogen oxides & $0.2-0.9$ \\
\hline Sulfur dioxide & $0.16-0.24$ \\
\hline Naphthalene & $0.24-1.6$ \\
\hline Substituted naphthalenes & $0.3-2.1$ \\
\hline Oxygenated monoaromatics & $1-7$ \\
\hline Total particle mass & $7-30$ \\
\hline Particulate organic carbon & $2-20$ \\
\hline Particulate elemental carbon & $0.3-5$ \\
\hline Oxygenated PAHs & $0.15-1$ \\
\hline PAHs & $10^{-5}-10^{-2}$ a) \\
\hline Trace elements & $10^{-4}-10^{-2}$ b) \\
\hline
\end{tabular}


a) 18 different PAHs listed with concentrations ranging from $10^{-4}-10^{-2} \mathrm{~g} / \mathrm{kg}$ wood.

b) 18 different trace elements listed with concentrations ranging from $10^{-4}-10^{-2} \mathrm{~g} / \mathrm{kg}$ wood.

O rganic compound emission rates for volatile organic compounds, gas-phase semi-volatile organic compounds, and particle-phase organic compounds have been measured from residential fireplace combustion of wood. Firewood from a conifer tree (pine) and from two deciduous trees (oak and eucalyptus) was analysed to determine organic compounds emissions profiles for each wood type. T he results are summarised in T able 2. (Schauer et al. 2001).

Table 2. Aver age fine particl e emissions $r$ ate and fine particl e chemical compo sition of emissions from fireplace co mbustion of wood. Reproduced from Schauer et al. (2001).

\begin{tabular}{|c|c|c|c|}
\hline & Pine & Oak & Eucalyptus \\
\hline $\begin{array}{l}\text { Fine particle emissions rate } \\
\text { (g/kg wood burned) }\end{array}$ & $9.5 \pm 10$ & $5.1 \pm 0.5$ & $8.5 \pm 0.8$ \\
\hline Organic carbon (wt\% FPM ${ }^{\mathrm{a}}$ ) & $56.0 \pm 2.8$ & $59.1 \pm 3.0$ & $43.7 \pm 2.2$ \\
\hline Elemental carbon (wt\% FPM ${ }^{a}$ ) & $14 \pm 0.1$ & $3.2 \pm 0.2$ & $2.6 \pm 0.2$ \\
\hline Chloride (wt\% FPM $\left.{ }^{a}\right)$ & $0.29 \pm 0.04$ & $0.20 \pm 0.01$ & $1.70 \pm 0.05$ \\
\hline Nitrate (wt\% FPM $\left.{ }^{a}\right)$ & $0.19 \pm 0.01$ & $0.44 \pm 0.01$ & $0.45 \pm 0.01$ \\
\hline Sulphate (wt\% FPM $\left.{ }^{a}\right)$ & $0.12 \pm 0.01$ & $0.41 \pm 0.01$ & $0.24 \pm 0.01$ \\
\hline Ammonium (wt\% FPM ${ }^{\mathrm{a}}$ ) & $0.09 \pm 0.01$ & $0.10 \pm 0.01$ & $0.45 \pm 0.01$ \\
\hline Sodium $\left(w t \% ~ F P M{ }^{a}\right)$ & $0.09 \pm 0.01$ & $0.10 \pm 0.01$ & $0.18 \pm 0.01$ \\
\hline Sulphur (wt\% FPM ${ }^{a}$ ) & $0.059 \pm 0.002$ & $0.148 \pm 0.004$ & $0.056 \pm 0.003$ \\
\hline Chlorine (wt\% FPM ${ }^{\mathrm{a}}$ ) & $0.181+0.003$ & $0.127 \pm 0.006$ & $01.290 \pm 0.008$ \\
\hline Potassium (wt\% FPM ${ }^{a}$ ) & $0.277 \pm 0.003$ & $0.647 \pm 0.007$ & $0.809 \pm 0.005$ \\
\hline
\end{tabular}

a) FPM : Fine Particle Mass

K ocbach et al. (2006) found that residential wood smoke particles and diesel particles had a very comparable total carbon content ( 83 versus $80 \%$ ). H owever, the organic content was $35 \%$ for wood smoke particles compared to $16 \%$ for diesel particles. The PAH content in wood smoke was found to be $11800 \mathrm{ng} / \mathrm{mg}$, which was significantly higher than the PAH content in diesel particles of $84 \mathrm{ng} / \mathrm{mg}$.

T he emissions of particles, PAH s and dioxins were measured in smoke samples from private wood stove chimneys in D enmark ( $G$ lasius et al. 2005). T he results are summarised in T able 3 (I-T EQ are International T oxicity Equivalents). T he emissions of PAH s were $43.4 \pm 46.2 \mathrm{mg} / \mathrm{kg}$ wood (with values in the interval $4.4-81.2 \mathrm{mg} / \mathrm{kg}$ wood) and the particle emission $21.1 \pm 28.9 \mathrm{~g} / \mathrm{kg}$ wood $(3.2-82.9 \mathrm{~g} / \mathrm{kg}$ wood). Insufficient combustion conditions will lead to increased emission of both particle mass and PAHs, and a positive correlation between the emissions of PAH $\mathrm{s}$ and particles was seen. The dioxin emission was 6.1 $26.1 \mathrm{ng} \mathrm{I-T} \mathrm{EQ/kg} \mathrm{wood} \mathrm{(0.3-17.7} \mathrm{ng} \mathrm{I-}$ $\mathrm{TEQ} / \mathrm{kg}$ wood), and no correlation between the emission of dioxins and particles were found. D ioxins and particles are formed via two different processes and therefore no correlation was expected. D ioxins are formed by a chemical reaction between chlorine and organic substances while particles are formed via condensation of the flue gas. 
In a recent follow-up study on 13 appliances of which six were also included in the study reported in G lasius et al. (2005), the average emissions were PAH $57 \pm 83 \mathrm{ng} / \mathrm{kg}$ wood, dioxins $19 \pm 32 \mathrm{ng}$ l-TE Q $/ \mathrm{kg}$ wood and particles $6.2 \pm 5.4 \mathrm{mg} / \mathrm{kg}$ wood (G lasius et al. 2007). G enerally the results were in agreement with the first study, except for particle emissions that were lower in the second study. T he large relative standard deviations in the measurements are caused by the large variation in emissions between appliances.

A recent inventory shows that the total $D$ anish dioxin emission to air was about $22.0 \mathrm{~g} \mathrm{I-T} \mathrm{EQ} \mathrm{in} \mathrm{2004.} \mathrm{T} \mathrm{he} \mathrm{main} \mathrm{sources} \mathrm{were} \mathrm{residential} \mathrm{wood}$ combustion (40\%) and fires (28\%) (H enriksen et al. 2006).

Table 3. Wo od smoke emissions from private wood burning stoves. Reproduced from Gl asius et al. (2005).

\begin{tabular}{|l|c|c|c|}
\hline & New stoves <3 years & Old stoves $>5$ years & Old boiler \\
\hline Number of determinations & 3 & 6 & 2 \\
\hline Dioxin $\left(\mathrm{ng} \mathrm{l-TEQ} / \mathrm{kg}^{3}\right.$ wood) & $0.3-3.0$ & $5.1-17.7$ & $0.3-0.6$ \\
\hline Dioxin $\left(\mathrm{ng} \mathrm{l-TEQ} / \mathrm{m}^{3}\right.$ smoke) & $0.05-0.46$ & $0.79-2.7$ & $0.045-0.094$ \\
\hline $\mathrm{PAH}(\mathrm{mg} / \mathrm{kg} \mathrm{wood})$ & $4.4-7.8$ & $5.5-81.2$ & $15.4-23.7$ \\
\hline $\mathrm{PAH}\left(\mathrm{mg} / \mathrm{m}^{3}\right)$ & $0.7-1.2$ & $0.8-12.4$ & $2.3-3.6$ \\
\hline Particles $(\mathrm{g} / \mathrm{kg} \mathrm{wood})$ & $4.3-11.4$ & $3.2-82.9^{*}$ & $20.3-24.2$ \\
\hline Particles $\left(\mathrm{mg} / \mathrm{m}^{3}\right)$ & $0.7-1.7$ & $0.5-12.7 *$ & $3.1-3.7$ \\
\hline
\end{tabular}

* 4 determinations.

The type of wood burned was mostly dried birch and beech. $\mathrm{N}$ ot included in this Table was a smoke sample taken from a new stove during combustion of pallets and painted wood. In this sample, the emission per $\mathrm{kg}$ wood of PAH, dioxin, and particles compared to clean wood was increased 5-, 4-, and 8-fold, respectively. 


\section{Human exposure}

\subsection{Exposure from ambient air}

\subsubsection{Particles}

W ood burning devices contribute to outdoor air pollution. T he contribution of wood smoke particles to ambient air pollution has recently been summarised by Zelikoff et al. (2002). On a moderately cold winter day, 51\% of the respirable air particulates in the Portland, OR, area were from residential wood combustion sources (C ooper 1980). Investigations examining other parts of the northwest A merica reported that residential wood smoke in the Olympia, W A, area accounted for $50 \%$ (on clear days) to $85 \%$ (on polluted days) of airborne PM and it was concluded that wood smoke represented a more significant source of ambient PM than the sum of total of all industrial point sources in the state of Washington (K oenig et al. 1988). A dditional studies in the same geographic area have demonstrated that 80-90\% of the PM measured in the ambient air was due to use of wood burning devices during night time hours ( $L$ arson et al. 1992).

L arson \& K oenig (1994) have summarised a number of studies, which have documented the outdoor concentrations of airborne particles resulting from wood burning. T he studies indicated that wood smoke may account for up to $90 \%$ of the airborne particle concentrations during the winter. In cases where wood smoke contributed predominantly to the particulate mass ( $>80 \%$ ), $\mathrm{PM}_{10}$ concentrations up to about $150 \mu \mathrm{g} / \mathrm{m}^{3}$ and $\mathrm{PM}_{2.5}$ concentrations up to about $85 \mu \mathrm{g} / \mathrm{m}^{3}$ have been reported.

In a more recent review (Boman et al. 2003) including nine studies (see T able 6 in section 5.1.2.2) in relation to residential wood combustion, 24-hour PM ${ }_{10}$ concentrations up to $187 \mu \mathrm{g} / \mathrm{m}^{3}$ were reported with average values (mean) of about 20-30 $\mu \mathrm{g} / \mathrm{m}^{3}$ in most studies. O ne American study has reported a 24hour mean $\mathrm{PM}_{2.5}$ of $16.7 \mu \mathrm{g} / \mathrm{m}^{3}$ (Sheppard et al. 1999) and another A merican study has reported an average concentration of $\mathrm{PM}_{2.5}$ of approximately 12 $\mu \mathrm{g} / \mathrm{m}^{3}$ for a 15 -month period ( $\mathrm{N}$ orris et al. 1999).

In a recent Swedish study (M olnár et al. 2005), outdoor levels of $\mathrm{PM}_{2.5}$ were measured in the winter 2003 in a residential area where domestic wood burning is common; the mean value was $13.7 \pm 8.0 \mu \mathrm{g} / \mathrm{m}^{3}$.

D ata from $\mathrm{N}$ ordic countries have shown that emissions from wood stoves depend very much on the combustion conditions and technologies (Sternhufvud et al. 2004). Old stoves are still the most important PM emission source compared with newer types of stoves with improved technology.

In 2005, there were about 551,000 wood stoves and about 48,000 wood boilers in D enmark ( $E$ vald 2006). Recent results have shown that the particle emission from residential wood burning stoves is an important source of particles in ambient air pollution in D enmark. According to Illerup \& $\mathrm{N}$ ielsen 
(2004), about 10,000 tonnes $\mathrm{PM}_{2.5}$ per year or about half of the total particle emission in D enmark come from residential wood combustion. In 2005, the total particle emission was about 27,787 tonnes PM ${ }_{2.5}$ in D enmark of which about 17,665 tonnes $\mathrm{PM}_{2.5}$ were from residential wood combustion (M ST 2007). A nother important source is road traffic, which contributes with about $20 \%$ of the total emission of $\mathrm{PM}_{2.5}$ (Palmgren et al. 2005).

There is only very limited information on population exposure to wood smoke particles in D enmark. Only data from two measurement campaigns can be used to estimate the particle contributions from local wood combustion.

$M$ easurements in a $D$ anish residential area with no district heating and many wood stoves during the winters 2002 and 2003/4 have shown that the vast majority of $\mathrm{PM}_{2.5}$ pollution stems from three sources: long-range transport, traffic and wood combustion. T he highest contribution to $\mathrm{PM}_{2.5}$ was from long-range transported pollution, mainly salts. $M$ easurements during a 6 -week winter period showed that the contribution from wood combustion to ambient $\mathrm{PM}_{2.5}$ was comparable to the contribution from a heavily trafficked road to $\mathrm{PM}_{2.5}^{2.5}$ at the sidewalk. The 24-hour range of $\mathrm{PM}_{2.5}$ in ambient air was about $12-19 \mu \mathrm{g} / \mathrm{m}^{3}$ (it is important to note that the applied measurement method underestimates $\mathrm{PM}_{2.5}$ by about $30 \%$ compared to the reference method). T he average $\mathrm{PM}_{2.5}$ concentration was elevated by about $4 \mu \mathrm{g} / \mathrm{m}^{3}$ compared to background measurements during the six winter weeks ( $G$ lasius et al. 2006). $M$ easurements in the $D$ anish residential area also showed increased ambient air concentrations of dioxin and PAH. (Vikelsøe et al. 2005, Palmgren et al. 2005).

In another residential area with natural gas combustion as the primary heating source and wood combustion as a secondary heating source, the average PM ${ }_{2.5}$ concentration was elevated by about $1 \mu \mathrm{g} / \mathrm{m}^{3}$ compared to background measurements during four winter weeks ( $G$ lasius et al. 2007).

Based on these limited datasets, the general population exposure can only be estimated with very large uncertainties. In addition to lack of measurements, there is presently a lack of information on e.g. the actual geographic distribution of the wood-combustion appliances and the number of people living in the vicinity.

An increase in annual average $\mathrm{PM}_{2.5}$ of $1 \mu \mathrm{g} / \mathrm{m}^{3}$ is a best maximum estimate of the whole population exposure based on the data from these two measurement campaigns showing an increase in average $\mathrm{PM}_{2.5}$ of $4 \mu \mathrm{g} / \mathrm{m}^{3}$ during winter in a residential area with no district heating and many wood stoves and of $1 \mu \mathrm{g} / \mathrm{m}^{3}$ during winter in a residential area with natural gas combustion as the primary heating source and wood combustion as a secondary heating source.

$M$ odel calculations have been used to estimate the $P M_{2.5}$ levels resulting from wood combustion in D enmark. T he total D anish $P M_{2.5}$ emissions from woodcombustion were assumed to be distributed evenly over the whole area of D enmark, and the results showed an increase in $\mathrm{PM}_{2.5}$ of $0.4 \mu \mathrm{g} / \mathrm{m}^{3}$ during winter (O ctober-M arch) corresponding to an increase in annual $\mathrm{PM}_{2.5}$ of 0.2 $\mu \mathrm{g} / \mathrm{m}^{3}$ (Palmgren et al. 2005). An increase in annual $P M_{2.5}$ of $0.2 \mu \mathrm{g} / \mathrm{m}^{3}$ is a best minimum estimate of the whole population exposure.

In conclusion, the annual average $\mathrm{PM}_{2.5}$ exposure from wood smoke is roughly estimated to be $0.2-1 \mu \mathrm{g} / \mathrm{m}^{3}$ for the whole $D$ anish population with a best estimate of about $0.6 \mu \mathrm{g} / \mathrm{m}^{3}$. 
The contribution to $\mathrm{PM}_{2.5}$ from wood smoke of $0.2-1 \mu \mathrm{g} / \mathrm{m}^{3}$ should be seen in connection with the overall $\mathrm{PM}_{2.5}$ levels in D enmark. M easurements of $\mathrm{PM}_{2.5}$ in the centre of $C$ openhagen and in urban background showed $\mathrm{PM}_{2.5}$ concentrations of $19.8 \mu \mathrm{g} / \mathrm{m}^{3}$ in C entral Copenhagen and $14.6 \mu \mathrm{g} / \mathrm{m}^{3}$ in urban background (Jensen et al. 2004).

\subsubsection{PAH}

T he following data are not specifically addressing wood smoke PAH but pertain to PAH ambient air measurements with contribution from all sources.

In a recent study (Prevedouros et al. 2004), atmospheric monitoring data for selected PAHs have been compiled from remote, rural and urban locations in the UK, Sweden, Finland and A rctic C anada. U rban sites included L ondon and $\mathrm{M}$ anchester as well as the semi-rural site $\mathrm{H}$ azelrigg, rural locations were in Rörvik (Sweden) and Pallas (F inland), and the remote site was near A lert (Arctic $C$ anada). T able 4 gives the typical ranges for the compounds at each site for 1996 as a reference year.

T he sites differed substantially in PAH concentrations and represented a range along an urban, rural and remote gradient, i.e. a 'dilution' of ambient air concentrations at sites further away from major source regions. U rban centres in the UK had concentrations 1-2 orders of magnitude higher than in rural Europe and up to 3 orders of magnitude higher than in Arctic $C$ anada. T he concentrations from the semi-rural site $\mathrm{H}$ azelrigg may have been influenced by the proximity of a major highway and this could be the source to the observed elevated concentrations of some PAHs (most notably phenanthrene) at this site.

Seasonality, with winter concentrations being higher than summer concentrations, was apparent for most PAH s at most sites; high molecular weight compounds (e.g. benzo[a]pyrene) showed this most clearly and consistently. Strong winter>summer seasonality is linked to seasonally dependent sources, which are greater in winter, and photolytic degradation during summer. This implicates inefficient combustion processes, notably the diffuse domestic burning of wood and coal. However, sometimes seasonality can also be strongly influenced by broad changes in meteorology and air mass origin (e.g. in the Arctic C anada).

Table 4. Ranges of the PAH air concentrations ( $g$ as and particle) at the sel ected sites (in $\mathrm{ng} / \mathrm{m}^{3}$ ). Reproduced from Prevedouros et al. (2004).

\begin{tabular}{|l|l|l|l|l|l|l|}
\hline & London & Manchester & Hazelrigg & Rörvik & Pallas & Alert \\
\hline Acenaphthene & $0.7-1.5$ & $1-4$ & $0.5-2$ & $\mathrm{~N} / \mathrm{a}$ & $\mathrm{N} / \mathrm{a}$ & $0.001-0.02$ \\
\hline Fluorene & $3-9$ & $4-20$ & $5-20$ & $\mathrm{~N} / \mathrm{a}$ & $\mathrm{N} / \mathrm{a}$ & $0.01-0.3$ \\
\hline Phenanthrene & $20-22$ & $20-50$ & $70-160$ & $0.8-3$ & $0.2-0.7$ & $0.02-0.08$ \\
\hline Anthracene & $1-2$ & $1-4$ & $5-15$ & $0.01-0.1$ & $0.002-0.01$ & $0.002-0.003$ \\
\hline Fluoranthene & $4-6$ & $5-10$ & $5-10$ & $0.3-17$ & $0.1-0.3$ & $0.005-0.07$ \\
\hline Pyrene & $2.5-5$ & $3.5-8$ & $5-10$ & $0.1-1$ & $0.05-0.2$ & $0.004-0.05$ \\
\hline Benzo[a]anthracene & $0.2-0.9$ & $0.2-16$ & $0.3-0.7$ & $0.01-0.2$ & $0.005-0.02$ & $\mathrm{~N} / \mathrm{d}-0.020$ \\
\hline Chrysene & $0.5-2$ & $0.4-6$ & $0.25-1$ & $0.05-0.5$ & $0.03-0.04$ & $\mathrm{~N} / \mathrm{d}-0.050$ \\
\hline Benzo[b]fluoranthene & $0.2-15$ & $0.2-15$ & $0.05-1$ & $0.04-0.8$ & $0.02-0.05$ & $\mathrm{~N} / \mathrm{d}-0.012$ \\
\hline Benzo[k]fluoranthene & $0.1-1$ & $0.1-1$ & $0.02-0.4$ & $0.01-0.3$ & $0.01-0.02$ & $\mathrm{~N} / \mathrm{d}-0.01$ \\
\hline Benzo[a]pyrene & $0.05-0.6$ & $0.1-1$ & $\mathrm{~N} / \mathrm{a}$ & $0.01-0.2$ & $0.01-0.03$ & $\mathrm{~N} / \mathrm{d}-0.004$ \\
\hline Benzo[ghi]perylene & $0.3-10$ & $0.2-0.8$ & $0.02-0.5$ & $0.02-0.15$ & $0.01-0.04$ & $\mathrm{~N} / \mathrm{d}-0.013$ \\
\hline
\end{tabular}

$\mathrm{N} / \mathrm{a}$ : N ot analysed.

$\mathrm{N} / \mathrm{d}$ : N ot detected. 


\subsection{Indoor penetration}

T he transport properties of particulate air pollution strongly depend on the particle size distribution. Sub-micrometer particles can easily penetrate into the indoor environment, especially if air filtration does not occur.

Although wood smoke levels in outdoor air are important, most people spend a majority of their time indoor, especially at night in residential areas. T hus indoor penetration is an important variable when interpreting the exposure assessment. Indoor exposure can occur not only from infiltration of outdoor air, but also from emissions into the home from a wood burning appliance. It has been estimated that approximately $70 \%$ of the fine particles from the outside air penetrate into the home. For an outdoor concentration of $20 \mu \mathrm{g} / \mathrm{m}^{3}$ of wood smoke particles, there is an effective infiltration rate of $1 \mathrm{mg} / \mathrm{hour}$ of fine particle mass if $7 / 10$ of the volume of air in the room is exchanged with outside air every hour. $\mathrm{H}$ igher outdoor concentrations or more rapid air exchange rates would give larger infiltration rates. For most studies of fine particle mass in homes with airtight stoves, the indoor-outdoor ratios are at or below 1.0 implying that infiltration is important even in homes with stoves. ( $L$ arson \& K oenig 1994).

T he number concentration of ultrafine and fine particles was measured simultaneously indoor and outdoor in some rural and urban areas of Sweden and $D$ enmark ( $M$ atson 2005). T he results revealed that the outdoorgenerated particle levels were major contributors to the indoor particle number concentration in the studied buildings when no strong internal source was present. T he determined indoor-outdoor ratios varied between 0.5 and 0.8 . In residential buildings, the indoor number concentration was strongly influenced by several indoor activities, e.g., cooking and candle burning. In the presence of significant indoor sources, the indoor/outdoor ratio exceeded unity.

In a $\mathrm{D}$ anish study, 15 one-week samples of $\mathrm{PM}_{1}, \mathrm{PM}_{2.5}$, inhalable dust $\left(\mathrm{PM}_{\mathrm{inh}}\right)$ and 16 polycyclic aromatic hydrocarbons ( $\mathrm{PAHS}$ ) were collected inside and outside of an uninhabited $4^{\text {th }}$ floor apartment at Jagtvej in central Copenhagen during winter, spring and summer in 2002 (Jensen et al. 2005). Similarly, urban background samples were collected at a $2 \mathrm{~km}$ distant $4^{\text {th }}$ floor high rooftop.

The particulate air pollution was dominated by fine particles. A pproximately 70 wt $\%$ of the $\mathrm{PM}_{2.5}$ consisted of $\mathrm{PM}_{1}$ at all sites. The average $\mathrm{PM}_{2.5}$ content in $\mathrm{PM}_{\text {inh }}$ was 54 and $69 \mathrm{wt} \%$ at Jagtvej and in the urban background, respectively. Indoor $\mathrm{PM}_{\text {inh }}$ consisted almost entirely of $\mathrm{PM}_{2.5}$. Correlation analysis showed a strong relationship between $\mathrm{PM}_{1}, \mathrm{PM}_{2.5}$ and $\mathrm{PM}_{\text {inh }}$ at Jagtvej and in the urban background. However, PM at Jagtvej exceeded the urban background concentrations.

Indoor PM correlated well with PM in both the street and the urban background. H owever, indoor-outdoor ratios below unity $\left(0.77 \pm 0.21\right.$ for $\mathrm{PM}_{1}$ and $0.77 \pm 0.24$ for $\mathrm{PM}_{2.5}$ ) were only achieved using $\mathrm{PM}$ concentrations measured in the street at Jagtvej.

In PM ${ }_{2.5}$ samples, the total concentrations of 16 PAH s were $15-284 \mathrm{ng} / \mathrm{m}^{3}$ indoor, $46-235 \mathrm{ng} / \mathrm{m}^{3}$ outdoor, and $2-105 \mathrm{ng} / \mathrm{m}^{3}$ in the urban background. $\mathrm{T}$ he concentrations were probably underestimated due to extraction recovery below $100 \%$, breakthrough, and reaction with ozone and nitrogen oxides during sampling. T he real concentrations may be up to two times higher than observed. U rban background, traffic and indoor sources contributed to the 
overall concentration of PAH s in the uninhabited apartment. T raffic in the Jagtvej street canyon and indoor sources appeared to be the most important sources for PAH s indoor.

Indoor-outdoor measurements of levoglucosan (a chemical marker for wood smoke) have been carried out in two single-family detached houses in D enmark (Randers), one with and one without a wood stove ( $G$ lasius et al. 2007). M easurements of levoglucosan showed that the house with a wood stove had increased levels compared with outdoor levels; the increased levels may thus be associated with use of a wood stove in the house. L evoglucosan was also measured in the house without a wood stove indicating that particles from outdoor are transported into the house.

\subsection{Exposurefromother settings with wood smoke}

Exposure to biomass air pollution occurs in many settings. T he highest concentrations of particles have been measured in indoor air in developing countries where wood and other biomass is used as a cooking and heating fuel. In terms of exposure, domestic cooking and heating with biomass clearly presents the highest exposures since individuals are exposed to high levels of smoke on a daily basis for many years.

Exposures during cooking with biomass fuel have been reviewed by Smith et al. (2000). Particulate concentrations in N epal were as high as 200-8200 $\mu \mathrm{g} / \mathrm{m}^{3}$, while measurements from India showed particle concentrations as high as $3600-6800 \mu \mathrm{g} / \mathrm{m}^{3}$. M easurements of particle concentrations in kitchen areas in developing countries have shown values between 200 and $9000 \mu \mathrm{g} / \mathrm{m}^{3}$.

Park \& L ee (2003) measured the particle exposure and size distribution in 23 houses with wood burning stoves in Costa Rica. D aily $\mathrm{PM}_{2.5}, \mathrm{PM}_{10}$ and particle size distribution were simultaneously measured in the kitchen. A verage daily $P M_{2.5}$ and $P M_{10}$ were 44 and $132 \mu \mathrm{g} / \mathrm{m}^{3}$, respectively. All houses had a particle size distribution of either one or two peaks at around 0.7 and $2.5 \mu \mathrm{m}$ aerodynamic diameters. T he maximum peak levels ranged from 310 to $8170 \mu \mathrm{g} / \mathrm{m}^{3}$ for $\mathrm{PM}_{2.5}$ and from 500 to $18900 \mu \mathrm{g} / \mathrm{m}^{3}$ for $\mathrm{PM}_{10}$.

F orest fire-fighters comprise an occupational group with high exposure to biomass smoke. In a recent study, the average daily personal exposure to fine particles was $882 \mu \mathrm{g} / \mathrm{m}^{3}$ with an interquartile range of $235 \mu \mathrm{g} / \mathrm{m}^{3}$ to $1317 \mu \mathrm{g} / \mathrm{m}^{3}$ (Slaughter et al. 2004). Concentrations of acrolein, formaldehyde, and carbon monoxide were similarly elevated. Exposures of this population are seasonal (4-5 months per year) and highly variable depending upon the number of fires per season, the intensity of the fires and specific job tasks. Fire-fighters are normally among the most physically fit in the population and do not normally suffer from any pre-existing health conditions. Accordingly, the absence of health impacts among this group does not indicate that health impacts will not be observed in the general population. As biomass combustion associated with forest fires is a special situation with high temperatures resulting in the emission of high levels of various compounds, the health effects of fire-fighters will not be discussed further in this report. 


\subsection{Summary of human exposure to particles from wood smoke}

M easurements of PM levels in areas with many wood stoves have consistently shown elevated levels of PM emissions during wintertime when wood burning is common. D ue to the size distribution of wood smoke particles essentially all will be contained in the $\mathrm{PM}_{2.5}$ fraction.

Studies from $\mathrm{N}$ orth A merican communities have reported 24-hour $\mathrm{PM}_{10}$ levels of up to $165 \mu \mathrm{g} / \mathrm{m}^{3}$ with average values (mean) of about $20-30 \mu \mathrm{g} / \mathrm{m}^{3}$ in most studies ( see T able 6). O ne A merican study (Sheppard et al. 1999) has reported a 24-hour mean $\mathrm{PM}_{2.5}$ of $16.7 \mu \mathrm{g} / \mathrm{m}^{3}$ and another A merican study ( $\mathrm{N}$ orris et al. 1999) has reported an average concentration of $\mathrm{PM}_{2.5}$ of approximately $12 \mu \mathrm{g} / \mathrm{m}^{3}$ for a 15 -month period. T he most recent A merican study (Schreuder et al. 2006) has reported a mean 24-hour PM ${ }_{2.5}$ of 10.6 $\mu \mathrm{g} / \mathrm{m}^{3}$ (95\% Cl: 8-86 $\mu \mathrm{g} / \mathrm{m}^{3}$ ).

In one study from $\mathrm{N}$ ew Zealand ( $\mathrm{H}$ ales et al. 2000), the 24-hour PM ${ }_{10}$ levels were up to $187 \mu \mathrm{g} / \mathrm{m}^{3}$ with a mean of $28 \mu \mathrm{g} / \mathrm{m}^{3}$.

In a recent Swedish study ( $M$ olnár et al. 2005), the mean winter outdoor level of $\mathrm{PM}_{2.5}$ was $13.7 \mu \mathrm{g} / \mathrm{m}^{3}$ in a residential area where domestic wood burning is common.

T here is only very limited information on population exposure to wood smoke particles in D enmark.

M easurements during a 6-week winter period (2002 and 2003/4) in a D anish residential area with no district heating and many wood stoves showed that the contribution from wood combustion to ambient $\mathrm{PM}_{2.5}$ was comparable to the contribution from a heavily trafficked road to $\mathrm{PM}_{2.5}$ at the sidewalk. The average local $\mathrm{PM}_{2.5}$ contribution from wood combustion was about $4 \mu \mathrm{g} / \mathrm{m}^{3}$ ( $G$ lasius et al. 2006).

In another residential area with natural gas combustion as the primary heating source and wood combustion as a secondary heating source, the average PM ${ }_{2.5}$ concentration was elevated by about $1 \mu \mathrm{g} / \mathrm{m}^{3}$ compared to background measurements during four winter weeks ( $G$ lasius et al. 2007).

An increase in annual average $\mathrm{PM}_{2.5}$ of $1 \mu \mathrm{g} / \mathrm{m}^{3}$ is a best maximum estimate of the whole population exposure based on the data from the measurements in these two residential areas.

Based on the total particle emission from residential wood burning, model calculations have been used to estimate the contribution to the $\mathrm{PM}_{2.5}$ levels. $T$ he results showed an increase in annual $P M_{2.5}$ of $0.2 \mu \mathrm{g} / \mathrm{m}^{3}$ (as a best minimum estimate) for the whole population exposure (Palmgren et al. 2005).

In conclusion, the annual average $\mathrm{PM}_{2.5}$ exposure from wood smoke is roughly estimated to be $0.2-1 \mu \mathrm{g} / \mathrm{m}^{3}$ for the whole $D$ anish population with a best estimate of about $0.6 \mu \mathrm{g} / \mathrm{m}^{3}$.

T he sub-micrometer particles can easily penetrate into the indoor environment, especially if air filtration does not occur. A recent Swedish study ( $M$ atson 2005) has revealed that the outdoor-generated particle levels were major contributors to the indoor particle concentration when no strong internal source was present and the determined indoor-outdoor ratios varied between 0.5 and 0.8 .

Recent $D$ anish indoor-outdoor measurements of levoglucosan (a chemical marker for wood smoke) showed increased indoor levels compared with outdoor levels in a house with a wood stove indicating that the increased levels 
may be associated with use of a wood stove in the house. L evoglucosan was also measured in a house without a wood stove indicating that particles from outdoor are transported into the house. (G lasius et al. 2007). 


\section{Toxicokinetics}

\subsection{Particle deposition in the respiratory tract}

The deposition of inhaled particles depends on particle size, breathing pattern and lung structure (Sarangapani \& W exler 2000). G enerally, as the particle size and breathing rate increases, particles deposit higher in the airways than at smaller size and slower breathing rates.

The respiratory tract of both humans and animals can be divided into three general regions on the basis of structure, size and function: the extrathoracic (mouth and throat), the trachea-bronchial and the alveolar regions.

In humans, inhalation can occur through the nose or mouth, while rodent animals, like the mouse, are obligatory nose breathers. D epending on the particle size and mass, varying degrees of deposition may occur in the extrathoracic, trachea-bronchial and alveolar region of the respiratory tract. In general, particles larger than $4 \mu \mathrm{m}$ and below $0.002 \mu \mathrm{m}$ tend to deposit in the extrathoracic region, whereas particles in the fraction size $0.002-0.2 \mu \mathrm{m}$ deposit in the alveolar region (L ippmann \& Albert 1969, Stahlhofen et al. 1980); see also Figure 2.

Particle depositions differ among species due to differences in size, airway entrance and airflow ( $L$ ippmann \& Schlesinger 1984). H owever, for particles smaller than $1 \mu \mathrm{m}$ there are only minor differences between human and rat in the upper respiratory tract fractional deposition ( $M$ enache et al. 1995). T he same pattern has been found for alveolar deposition of particles less than 0.1 $\mu \mathrm{m}$ (Schlesinger 1985).

\subsection{Clear ance and transl ocation}

The term "clearance" is used to describe the translocation, transformation and removal of particles from the various regions of the respiratory tract. Clearance mechanisms may be broadly classified into two groupings, namely absorptive, which is dissolution, or non-absorptive, which involves mechanical transport of intact particles. Particle solubility in terms of clearance refers to solubility in vivo within the fluid lining the airway surfaces. Soluble particles are mainly cleared via absorption through cell surfaces into the blood stream (Schlesinger 2000). Insoluble material like wood combustion particles are cleared from the respiratory tract by the mechanisms described in the following. Unless anything else is stated, the text refers to Schlesinger (2000).

Particles larger than $10 \mu \mathrm{m}$ are mainly deposited in the upper respiratory tract, from where they are removed by coughing, by expectoration or swallowed into the gastrointestinal tract. R elatively insoluble particles between 2.5 and $10 \mu \mathrm{m}$ are mainly deposited in the ciliated regions of the tracheobronchial airways and are removed by the "mucociliary escalator" toward the epiglottis where they are removed in the same way as the larger particles (see above). T his process is relatively effective with particles cleared within hours after exposure. 
Figure 2. Particle deposition. Regional deposition of inhal ed particles in the human respiratory tract. From The International Commission on Radiological Protection (ICRP 1994).

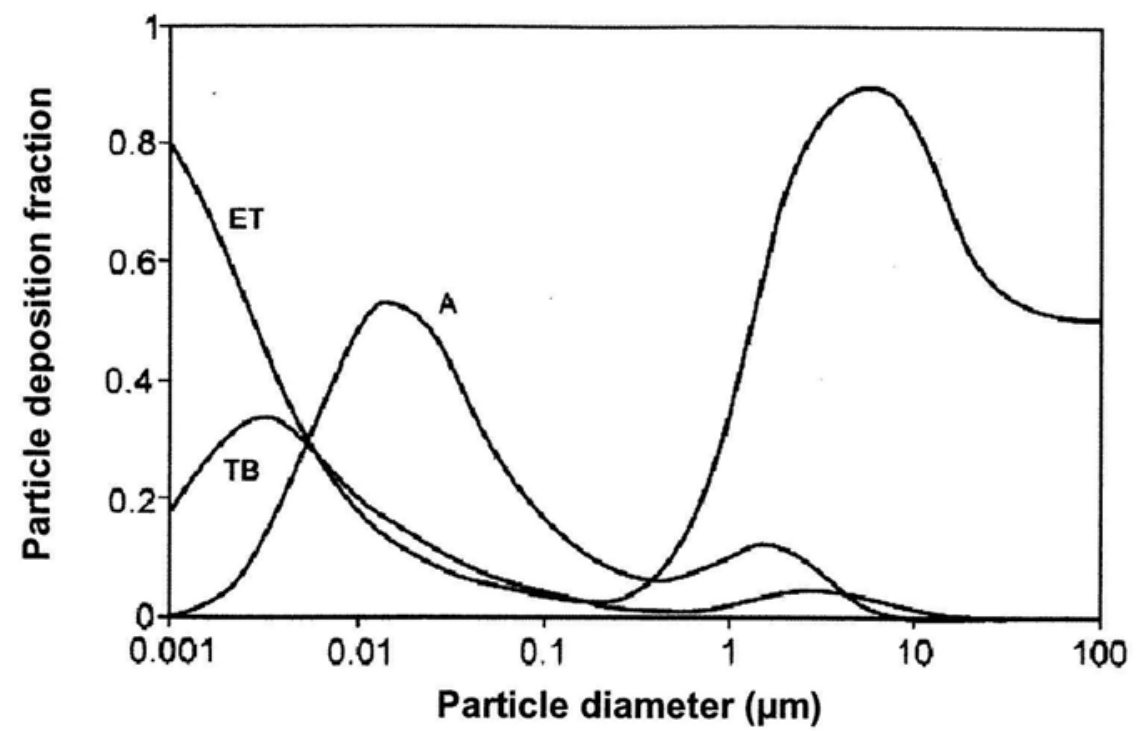

ET: Extrathoracic; TB: Trachea-bronchial; A: Alveolar

C learance of insoluble particles deposited in the alveolar region is slower (weeks to years) and occurs via a number of mechanisms. T he major pathway involves alveolar macrophages. T hese cells reside on the alveolar epithelium, and phagocytize and transport deposited material. T he primary route for clearance of the particle-laden macrophages is via the mucociliary escalator. $M$ acrophages, which are not cleared via the mucociliary system, may translocate to the interstitial tissue along with free particles. T his transepithelial passage of free particles seems to increase as particle loading increases, and may be particle size dependent, since insoluble ultrafine particles show greater lymphatic uptake than do larger ones ( $O$ berdörster et al. 1992). Particles and macrophages in the interstitium may enter the lymphatic system or traverse the alveolar-capillary endothelium, directly entering the blood. Passage through endothelial cells seems, however, to be restricted to particles $<0.1 \mu \mathrm{m}$. O nce in the systemic circulation, transmigrated macrophages, as well as free particles, can travel to extrapulmonary organs. Inhalation of ${ }^{13} \mathrm{C}$ particles showed rapid clearance within hours upon inhalation and translocation of ultrafine particles via blood circulation to the liver ( O berdörster et al. 2002). A ccordingly, it is important to consider extrapulmonary effects of inhaled particles.

T he basic mechanisms of clearance of deposited particles from the respiratory tract are similar for humans and most other mammals. H owever, regional clearance rates show substantial variation between species, even for similar particles deposited under comparable exposure conditions (Snipes 1989).

Polycyclic aromatic hydrocarbons (PAH s) are carried along with soot particles to the lungs following inhalation exposure and the extent of their metabolic activation is therefore an important factor to consider. Recent 
results indicate that absorption through the alveolar epithelium is an important route of entry to the circulation of unmetabolised PAH s ( $G$ erde et al. 2001). T he authors investigated the rate and extent of release and metabolic fate of benzo[a]pyrene ( $\mathrm{BaP}$ ) adsorbed on a carbonaceous core of diesel soot after exposure of dogs by inhalation. Following deposition in the alveolar region a fraction of $\mathrm{BaP}$ was rapidly desorbed from the soot and quickly absorbed into the circulation. R elease rates then decreased drastically. The rapidly released pulse of $\mathrm{BaP}$ appeared mostly un-metabolised in the circulation, along with low concentrations of phase I and phase II BaP metabolites. H owever, within about 1 hour, this rapidly absorbed fraction of $\mathrm{BaP}$ was systemically metabolised into mostly conjugated phase II metabolites. 


\section{Human health effects}

From the latest 10-15 years of toxicological and epidemiological research an extensive body of evidence has been generated documenting the adverse health effects resulting from ambient air PM . T he numerous epidemiological studies show a very consistent and uniform pattern with regard to different types of health outcomes and dose-response relationships.

A ssociations between adverse health effects and ambient air PM have typically been identified in relation to PM levels measured in the background urban air in general and these PM levels have been taken as a surrogate for the population exposure in the area. F rom such data it is generally very difficult to assess the health impacts of different sources of PM , as all PM sources are included in the PM levels in the background urban air. H owever, studies in which different fractions of PM have been analysed (e.g. elemental or organic carbon) and studies in which specific combustion related gaseous pollutants in addition to PM have been measured have shown that especially PM from combustion sources are important in relation to the adverse health effects.

Epidemiological studies have identified a variety of adverse health effects following acute (episodic increased) PM exposure as well as following longterm exposure. From an overall evaluation of these studies it is generally concluded that the adverse health effects are not solely linked to acute exposure from episodic increases. In contrary, the average level of long-term exposure over a year or more has a much stronger influence on public health compared to the effects calculated from them sum of episodes with increased PM levels within the same period.

A nother important finding is that it has not been possible to identify a lower threshold for adverse health effects, neither in connection with acute nor with long-term exposure. (WHO 2003, WHO 2004).

When assessing the adverse health effects of wood smoke and wood smoke PM , there are at least two different methodological approaches that can be used.

O ne approach would be to assess wood smoke PM as a part of PM in general and to benefit from the knowledge regarding adverse health effects from the PM area in general. Especially important in this approach would be to identify toxicological studies and epidemiological studies in which wood smoke PM has been identified as an important source of the total PM fraction. A nother, more classical toxicological, approach would be to separate the wood smoke into its different constituents and to evaluate the hazard and risk profile of each constituent. As shown in section 2, a variety of very toxic single constituents have been identified in wood smoke, e.g. benzo[a]pyrene and other carcinogenic PAHs, dioxins, a variety of heavy metals, and several volatile carcinogens such as formaldehyde, benzene and 1,3 butadiene. Although a hazard profile may be created by using this approach, it may be very difficult to evaluate the actual health risk of wood smoke as an evaluation also would require knowledge concerning the vast amount of possible physico-chemical and toxicological interactions between the several hundreds of different constituents in the wood smoke as well as of the toxicokinetic properties of the different constituents. 
F or ambient PM , Valberg $\&$ L ong (2003) has attempted to compare the levels of the individual constituents in ambient air and the toxicologically based human health reference concentration of the individual constituents. For none of the constituents, an unacceptable risk could be identified, as the human health reference concentration for a specific constituent generally was far below the actual level in ambient air. T his indicates that data on a single constituent is not sufficient in order to assess the risk and that the adverse health effects from PM can not at present be properly characterised by using this approach.

Consequently, the approach chosen in this report is to assess the adverse health effects of wood smoke PM based on the current knowledge on PM in general with focus on the epidemiological studies where wood smoke PM has been identified as an important source of the total PM fraction.

\subsection{Epidemiological studies, non-cancer heal th ef fects}

T he association of particulate air pollution with adverse health effects has long been known, especially in relation to respiratory and cardiovascular disease. T he fraction of very small particles probably constitutes one of the most important health problems in relation to air pollution (Brunekreef \& Holgate 2002). W HO has estimated that $1 \%$ of all heart- and lung diseases and $3 \%$ of respiratory cancer cases in the whole world is caused by particulate air pollution. This leads to 600,000 (1.2\%) early deaths and loss of 7.4 million (0.5\%) D AL Y s (D isease A djusted L ife Y ears). T he most significant air pollution problems are seen in the developing countries and in Central- and East Europe. It has recently been estimated that air pollution is responsible for 288,000 early deaths in the EU (CAFE CBA 2005).

O ur knowledge about quantitative associations between health effects and particulate air pollution is mainly based on epidemiological studies performed as cohort studies or time-series studies.

In cohort studies, population groups living in different areas with different levels of air pollution are studied, and cohort studies generally reflect effects following long-term exposure.

In time-series studies, one population group is studied and their health is related to changes in air pollution levels; time-series studies generally reflect effects following acute exposure episodes or short-term exposure. T he dose-response relationship, i.e., the relative risk for the various health outcomes studied, is substantially higher following long-term exposure when compared to acute or short-term exposure. T his indicates that long-term effects from air pollution is not just adding up the effects from acute shortterm episodes, but rather that long-term exposure raises the general level of mortality and morbidity in the population.

A limitation in both study designs is the exposure characterisation, which is usually based on data from a single monitoring site in the area, and assumed to be representative for all individuals in the area. A nother limitation is that most of the knowledge is based on fine particles $\left(\mathrm{PM}_{2.5}\right)$ and the sum of fine and coarse particles $\left(\mathrm{PM}_{10}\right)$, whereas knowledge on ultrafine particles is limited. 


\subsubsection{Particles in the general environment}

\subsubsection{E ffects from short-term exposure, time series studies}

Early air pollution episodes, such as in 1952 in L ondon, were dramatic examples of the impact of air pollution on mortality and other health effects (L ogan 1953). D uring this episode the daily levels of particles, measured as soot, increased 10-fold compared to the "normal" levels at that time of 300$500 \mu \mathrm{g} / \mathrm{m}^{3}$ (which is more than 10-fold the levels seen today). T hese air pollution episodes were the motivation for regulations and consequent air quality improvements in the past 30-40 years. T he effect of air pollution control was clearly observed in D ublin in the 1990s when coal sales were banned and residential heating with coal was stopped (Clancy et al. 2002). A bout 116 fewer respiratory deaths and 243 fewer cardiovascular deaths were seen per year in D ublin after the ban.

Several time-series studies in USA and Europe have demonstrated that days with increased concentrations of particulate air pollution are associated with an increase in hospital admissions and death due to lung and cardiovascular disease, for example demonstrated in 10 European cities (Zanobetti et al. 2003).

A meta-analysis showed that an increase of $10 \mu \mathrm{g} / \mathrm{m}^{3} \mathrm{PM}_{10}$ is associated with $0.6 \%$ increased total mortality, $1.3 \%$ increased respiratory related deaths and $0.9 \%$ cardiovascular deaths in a city area in the first days after the $P M_{10}$ increase (Anderson et al. 2004). If the observation time is extended for 40 days, the effect on total mortality is as high as 1\% (Zanobetti et al. 2003). Especially patients with pre-existing respiratory or cardiovascular disease are at risk of these air pollution effects.

The time-series design has also been used in a study where ultrafine particles were measured in the German city Ehrfuhrt with about 300000 inhabitants (W ichmann et al. 2000). In this study, the effect of ultrafine particles on death due to cardiac and respiratory disease was comparable to the effect of $\mathrm{PM}_{2.5}$ and $P M_{10}$. This study has recently been updated using data on PM number and mass concentrations and death certificates during 1995-2001 (Stölzel et al. 2006). A significant association between total mortality and cardiorespiratory mortality and the number concentrations of ultrafine particles was found whereas the increased mortality in relation to particle mass $\left(P M_{10}\right)$ did not reach a significant response.

In another European study of A msterdam, Ehrfuhrt and $\mathrm{H}$ elsinki, it was found that effects on cardiac and respiratory disease correlated better with $\mathrm{PM}_{2.5}$ than with the ultrafine particles ( de $\mathrm{H}$ artog et al. 2003, Pekkanen et al. 2002).

\subsubsection{E ffects from long-term exposure, cohort studies}

O nly a few cohort studies are available at present.

D ockery et al. (1993) studied about 8000 persons in six cities, while Pope et al. (1995) studied about 550,000 persons in 151 city areas. Both studies showed a significant association between mortality and particle level $\left(\mathrm{PM}_{2.5}\right)$. T he increased mortality was most pronounced among persons with preexisting respiratory and cardiovascular disease. T he results of the studies were 
based on the general particle level in background areas and no estimation was made of the contribution from the traffic or other sources.

L aden et al. (2006) conducted a follow-up of the D ockery et al. (1993) six cities study from 1990 to 1998 . T hey found an increase of $16 \%$ in overall mortality associated with each $10 \mu \mathrm{g} / \mathrm{m}^{3} \mathrm{PM}_{2.5}$ as an overall mean during the period or an increase of $14 \%$ in relation to the annual mean of $\mathrm{PM}_{2.5}$ in the year of death. Particulate air pollution had decreased from the first to the second period (1974-1989 and 1990-1998). Overall, between the two periods a decrease in mortality of $27 \%$ was found for each $10 \mu \mathrm{g} / \mathrm{m}^{3}$ reduction in the $\mathrm{PM}_{2.5}$ level.

Pope et al. (2002) have made an update of their study population of 550,000 persons. H ealth effects were now registered until 1999 and the result of the new study was in accordance with the result from 1995. A clear and significant association between mortality and $\mathrm{PM}_{2.5}$ level was observed. There was a considerable reduction of about $1 / 3$ in $\mathrm{PM}_{2.5}$ level in the period from 1979-83 to 1999-2000 in all areas. In 1979-83, a difference in the annual mean of $10 \mu \mathrm{g} / \mathrm{m}^{3} \mathrm{PM}_{2.5}$ between the areas was associated with a difference in annual mortality of $4 \%$ while in the period of 1999-2000, a difference of 10 $\mu \mathrm{g} / \mathrm{m}^{3} \mathrm{PM}_{2.5}$ was associated with a difference in annual mortality of $6 \%$.

Jerret et al. (2005) studied 23,000 persons in the L os Angeles area for the period 1982-2000. T he population was a subset of the Pope et al. study; however, the exposure could be assessed more accurately as the exposure was determined using model extrapolations of PM - data from 23 measurement stations. After controlling for covariates, a $10 \mu \mathrm{g} / \mathrm{m}^{3}$ increase in the annual $\mathrm{PM}_{2.5}$ level was associated with an increase in mortality of $17 \%$. T he corresponding increase in ischaemic heart disease was 38\% and for lung cancer $46 \%$. Thus, this study found an association in relation to mortality that was three times higher than that of Pope et al. (2002). T he increase was judged to be due to a more accurate exposure assessment than in the prior studies. Furthermore, the authors suggested that a higher contribution of traffic PM in the L os Angeles area might have increased the adverse health outcome.

M iller et al. (2007) studied a cohort of 66,000 women (older than 50 years and without previous cardiovascular disease) from 36 U.S. metropolitan areas and analysed the association between $\mathrm{PM}_{2.5}$ and first appearance of cardiovascular events (coronary heart disease, cerebro-vascular disease, myocardial infarction, coronary re-vascularisation, stroke), and cardiovascular mortality. Each increase of $10 \mu \mathrm{g} / \mathrm{m}^{3} \mathrm{PM}_{2.5}$ was associated with a $24 \%(95 \%$ interval: $9-41 \%)$ increase in risk of cardiovascular event and a 76\% (95\% interval: $25-147 \%$ ) increase of death from cardiovascular disease. When differences in $\mathrm{PM}_{2.5}$ and cardiovascular mortality within cities (between 4 and 78 PM monitors per city) were studied this resulted in a considerable higher increased risk of cardiovascular mortality ( $128 \%$ increase per $10 \mu \mathrm{g} / \mathrm{m}^{3} \mathrm{PM}_{2.5}$ ) compared to intercity comparisons ( $58 \%$ increase per $10 \mu \mathrm{g} / \mathrm{m}^{3} \mathrm{PM} \mathrm{M}_{2.5}$ ). T hese findings show an even higher increased risk for cardiovascular mortality than described in the recent cohort studies where the whole adult population, i.e., both men and women were studied (L aden et al. (2006) - study of intercity comparisons; Jerret et al. (2005) - study of intra-city comparisons).

In a study from the $\mathrm{N}$ etherlands, a cohort of 5000 persons was studied from 1986 to 1994 ( H oek et al. 2002). Exposure was assessed using background 
levels of soot and $\mathrm{NO}_{2}$. M ortality caused by cardiopulmonary disease was 2fold increased for persons living less than $100 \mathrm{~m}$ from a highway or less than $50 \mathrm{~m}$ from a larger city road. Five percent of the D utch cohort lived near roads with heavy traffic, and the effect on mortality was 1.5-fold higher in this group compared to the remaining $95 \%$.

In a recent $\mathrm{N}$ orwegian cohort study, 16,209 men in 0 slo aged 40-49 years in 1972-73 were studied until 1998 ( $N$ afstad et al. 2004). T heir exposure to air pollution was assessed by estimating $\mathrm{NO}_{\mathrm{x}}$ at the home address in 1974-1978. T he study showed an increase in total mortality with a relative risk of 1.08 (95\% Cl 1.06-1.11). T he relative risk for death caused by respiratory disease was $1.16(95 \% \mathrm{Cl}, 1.06-1.26)$, for heart disease 1.08 (95\% Cl, 1.03-1.12). $\mathrm{T}$ hese results support the results from the earlier cohort studies and since $\mathrm{N} \mathrm{O}_{x}$ was used as exposure parameter, the results indicate that traffic is the most important particle source.

\subsubsection{Air quality standards}

Air quality standards have been set for particulate matter by different organisations and by federal and national institutions. T he basis for the air quality standards has been the adverse health effects and the dose-response associations observed in connection with ambient air PM levels in epidemiological studies. T he standard values are the maximum concentrations allowed when averaged over time, typically 24-hour concentrations and annual concentrations.

In the US, the US-EPA standards for 24 hours are $150 \mu \mathrm{g} / \mathrm{m}^{3}$ for $P M_{10}$ and 35 $\mu \mathrm{g} / \mathrm{m}^{3}$ for $\mathrm{PM}_{2.5}$. The annual standard for $\mathrm{PM}_{2.5}$ is $15 \mu \mathrm{g} / \mathrm{m}^{3}$ while the former annual standard of $50 \mu \mathrm{g} / \mathrm{m}^{3}$ for $P M_{10}$ has been revoked. (U S-EPA 2006).

T he EU Commission has recently proposed a 24-hour standard for $\mathrm{PM}_{10}$ of $50 \mu \mathrm{g} / \mathrm{m}^{3}$ and an annual standard of $40 \mu \mathrm{g} / \mathrm{m}^{3}$. For $\mathrm{PM}_{2.5}$, no 24 -hour standard has been set but an annual standard of $25 \mu \mathrm{g} / \mathrm{m}^{3}$ was set as a concentration cap. F urthermore, the existing annual ambient air $\mathrm{PM}_{2.5}$ levels (monitored in the period of 2008-2010) in the EU have to be reduced by $20 \%$ in 2020. (EU 2005).

T he W HO has recently set 24-hour air quality guidelines of $50 \mu \mathrm{g} / \mathrm{m}^{3}$ for $\mathrm{PM}_{10}$ and of $25 \mu \mathrm{g} / \mathrm{m}^{3}$ for $\mathrm{PM}_{2.5}$. The annual air quality guidelines were set to 20 $\mu \mathrm{g} / \mathrm{m}^{3}$ and $10 \mu \mathrm{g} / \mathrm{m}^{3}$ for $P M_{10}$ and $\mathrm{PM}_{2.5}$, respectively (WHO 2006). T he WHO states that combustion of wood and other biomass fuels are important sources contributing to the $\mathrm{PM}_{2.5}$ fraction. Based on the available data. it is further assumed that the health effects of $\mathrm{PM}_{2.5}$ from fossil and biomass combustion are broadly the same. W ith respect to dose-response associations, the WHO concludes that an increase in the annual level of $10 \mu \mathrm{g} / \mathrm{m}^{3} \mathrm{PM}_{2.5}$ is associated with an increase in the annual mortality of $6 \%$ in the population whereas an increase of $10 \mu \mathrm{g} / \mathrm{m}^{3}$ in the 24-hour $\mathrm{PM}_{2.5}$ level is associated with an increase in short-term mortality of $1 \%$.

\subsubsection{Particles from residential wood burning}

The particle emission from wood burning stoves has received much attention lately. Since these particles are combustion products, they are expected to have effects similar to other combustion particles, e.g. from traffic. The 
studies described in the following are summarised in T able 5 (indoor air) and T able 6 (ambient air).

Tabl e 5. Studies with indo or exposure to wo od smoke (l o w level)

\begin{tabular}{|l|l|l|l|}
\hline Population & Endpoints & Results & Reference \\
\hline Children & $\begin{array}{l}\text { Respiratory } \\
\text { symptoms }\end{array}$ & Increased cough and wheeze symptoms & Honicky et al. (1985) \\
\hline Adults & $\begin{array}{l}\text { Respiratory } \\
\text { symptoms }\end{array}$ & Exacerbation of asthma & Ostro et al. (1994) \\
\hline $\begin{array}{l}\text { Children and } \\
\text { adults }\end{array}$ & $\begin{array}{l}\text { Respiratory } \\
\text { symptoms }\end{array}$ & M ore respiratory illnesses and symptoms & Levesqu et al. (2001) \\
\hline Adults & $\begin{array}{l}\text { Respiratory } \\
\text { symptoms }\end{array}$ & No evidence of negative influence & Eisner et al. (2002) \\
\hline
\end{tabular}

No measurements were made of wood smoke exposure.

\subsubsection{Indoor air}

Several early studies focused on the presence of a wood stove in the home as a risk factor. Several studies indicate that wood stoves, especially older varieties can emit smoke directly into the home ( $L$ arson \& K oenig 1994). W hile these earlier studies strongly suggest that there are adverse health impacts associated with wood smoke exposure, their crude exposure assessments preclude more specific conclusions.

H onicky et al. (1985) studied 34 preschool children living in homes with wood stoves compared to 34 children in homes with other heating sources, mainly gas. O ccurrence of wheeze and cough was greater in the group of children living in homes with wood stoves. $\mathrm{N}$ o measurements were made of the wood smoke.

L evesqu et al. (2001) examined the frequency of respiratory symptoms and illnesses among occupants of wood-heated homes. O ut of the 89 houses included in the study, 59 had wood burning appliances. T here was no consistent relationship between the presence of a wood burning appliance and respiratory morbidity in residents. H owever, residents exposed to emissions from wood burning reported more respiratory illnesses and symptoms.

In a prospective cohort study of adults with asthma residing in D enver, C olorado, metropolitan area, a panel of 164 asthmatics recorded in a daily diary the occurrence of several respiratory symptoms as well as the use of wood stoves and fireplaces (O stro et al. 1994). It was found that that the use of wood stoves or fireplaces was related to more respiratory symptoms.

In contrast, another study of 349 adults with asthma living in $\mathrm{N}$ orthern California showed no evidence of a negative influence of indoor wood smoke exposure on adult asthma (Eisner et al. 2002). In that study based on telephone interviews, exposure to environmental tobacco smoke was clearly associated with worse severity of asthma symptoms.

\subsubsection{A mbient air}

$M$ ost of the studies described in the following were also included in a review by Boman et al. (203) concerning adverse health effects from ambient air 
pollution in relation to residential wood combustion. T he results of the studies included in this review are described below and summarised in T able 6 , and the review is further addressed in sections 5.1.2.2.1 and 5.1.2.2.2.

Several studies have evaluated adverse health effects in communities where wood smoke was a major, although not the only, source of ambient air particulate. A questionnaire study of respiratory symptoms compared residents of 600 homes in a high wood smoke pollution area of Seattle with 600 homes (questionnaires completed for one parent and two children in each residence) of a low wood smoke pollution area (Browning et al. 1990). PM ${ }_{10}$ concentrations averaged 55 and $33 \mu \mathrm{g} / \mathrm{m}^{3}$ in the high and low exposure areas, respectively. When all age groups were combined, no significant differences were observed between the high and low exposure areas. H owever, there were statistically significant higher levels of congestion and wheezing in 1-5 year old children between the two areas for all three questionnaires (one baseline questionnaire and two follow-up questionnaires which asked about acute symptoms).

A more comprehensive study in the same high exposure Seattle area was initiated in 1988 (K oenig et al. 1993). D uring the heating season $80 \%$ of the particles is from wood smoke in these residential areas in Seattle ( $L$ arson \& K oenig 1994). L ung function was measured in 326 (including 24 asthmatics) elementary school children before, during and after two wood burning seasons. Fine particulates were measured continuously with an integrating nephelometer. Significant lung function decrements were observed in the asthmatic subjects, in association with increased wood smoke exposure. The highest (night-time 12-hour average) $\mathrm{PM}_{2.5}$ level measured during the study period was approximately $195 \mu \mathrm{g} / \mathrm{m}^{3}$ and PM ${ }_{10}$ levels were below the US $N$ ational A mbient Air Q uality Standard of $150 \mu \mathrm{g} / \mathrm{m}^{3}$ during the entire study period. For the asthmatic children FEV 1 and FVC decreased by 17 and 18.5 $\mathrm{ml}$ for each $10 \mu \mathrm{g} / \mathrm{m}^{3}$ increase in $\mathrm{PM}_{25}$, while no significant decreases in lung function were observed in the non-asthmatic children.

A companion study evaluated the impact of particulate matter on emergency room visits for asthma in Seattle during the period September 1989 through September 1990 (Schwartz et al. 1993). In this study a significant association was observed between $\mathrm{PM}_{10}$ particle levels and emergency room visits for asthma for persons under age 65. T he mean $\mathrm{PM}_{10}$ level during the 1-year study period was $30 \mu \mathrm{g} / \mathrm{m}^{3}$ (range $6-103 \mu \mathrm{g} / \mathrm{m}^{3}$ ). The daily risk for a $30 \mu \mathrm{g} / \mathrm{m}^{3}$ increase on $\mathrm{PM}_{10}$ was $1.12(95 \% \mathrm{Cl} 1.20-1.04)$. T he study showed clear evidence of a dose-response relationship, but did not identify a threshold below which effect were not observed.

Yu et al. (2000) observed a panel of 133 children (5-13 years of age) with asthma residing in Seattle, W ashington, for an average of 58 days (range 28112 days) in the period N ovember 1993 through A ugust 1995. T he daily average levels of $\mathrm{PM}_{10}$ and $\mathrm{PM}_{1.0}$ were $25 \mu \mathrm{g} / \mathrm{m}^{3}$ (range 8-86) and 10.4 (range 2-62), respectively. Increased exposure to air pollutants, specifically $\mathrm{CO}$ and $P M$, was associated with increased odds of at least one mild asthma symptom, like use of medication and night awakening for asthma. D ata for C O, PM and $\mathrm{SO}_{2}$ was measured at 6,3 and 1 monitoring sites, respectively. PM was measured both as $\mathrm{PM}_{10}$ and $\mathrm{PM}_{1.0}$ by gravimetric and/or nephelometric methods. 
Sheppard et al. (1999) investigated the relation between ambient air pollutants in Seattle, Washington and hospital admissions for asthma in the period 1987 through 1994. All persons were $<65$ years of age and 23 hospitals were included in the study. D ata on $\mathrm{PM}_{10}$ and $\mathrm{PM}_{2.5}$ were available from three and two monitoring sites, respectively. Four monitoring sites provided data for $\mathrm{CO}$, while $\mathrm{SO}_{2}$ and $\mathrm{O}_{3}$ were measured at one site each. The daily average levels of $P M_{10}$ and $P M_{2.5}$ were $31.5 \mu \mathrm{g} / \mathrm{m}^{3}$ and $16.7 \mu \mathrm{g} / \mathrm{m}^{3}$, respectively. An estimated $4-5 \%$ increase in the rate of asthma hospital admissions was found to be associated with an interquartile range change in $\mathrm{PM}_{10}$ or $\mathrm{PM}_{2.5}$ after a lag of one day. Positive associations were also found for $\mathrm{O}_{3}$ and $\mathrm{CO}$ after a lag of two and three days, respectively.

In a study by $\mathrm{N}$ orris et al. (1999), they found a significant association between fine particles ( $P M_{10}$ and $\mathrm{PM}_{2.5}$ ) and daily hospital admissions for asthma in Seattle during September 1995 to D ecember 1996. Six hospitals were included in the study and only data for persons $<18$ years of age was used. $\mathrm{D}$ ata on $\mathrm{PM}_{10}$ and $\mathrm{PM}_{2.5}$ were available from three monitoring sites. $\mathrm{CO}$ data was obtained from four sites, and $\mathrm{SO} 2, \mathrm{NO} 2$ and $\mathrm{O} 3$ from one site each. The daily average level of $P M_{10}$ was $22 \mu \mathrm{g} / \mathrm{m}^{3}$ ( range $\left.8-70 \mu \mathrm{g} / \mathrm{m}^{3}\right)$. A change of 11 $\mu \mathrm{g} / \mathrm{m}^{3}$ in fine PM $(<2.5 \mu \mathrm{m})$ was associated with a relative rate of $1.15(95 \%$ $\mathrm{Cl}$ 1.07-1.23). An increase in $\mathrm{CO}$ was also associated with hospital visits for asthma. T he majority of the hospital admissions were for children younger than 5 years of age. 
Tabl e 6. Epidemiol ogical studies with residential wood smoke as a major exposure source.

\begin{tabular}{|c|c|c|c|c|c|}
\hline Location, period & Design, study group & Variables & Exposure & Results & Reference \\
\hline $\begin{array}{l}\text { Seattle, Washington, } \\
\text { US }\end{array}$ & Cohort study, all ages & $\begin{array}{l}\text { Symptoms, respiratory } \\
\text { illness }\end{array}$ & $\begin{array}{l}\text { Mean } \mathrm{PM}_{10} 55 \mathrm{vs} .33 \mu \mathrm{g} / \mathrm{m}^{3} \text { (high } \\
\text { and low exp. area) }\end{array}$ & No significant effects. Trend for children aged 1-5 & Browning et al. (1990) \\
\hline Santa Clara County, US & All ages & Mortality & & Increased daily mortality & Fairley (1990) \\
\hline $\begin{array}{l}\text { Seattle, Washington, } \\
\text { US; winter season } \\
1988-89 \text { and 1989-90 }\end{array}$ & $\begin{array}{l}\text { Panel study, follow-up, } \\
326 \text { children (1st year), } \\
20 \text { children ( } 2 \text { nd year) }\end{array}$ & Lung function & $\begin{array}{l}\mathrm{PM}_{10} \text { levels below the US air quality } \\
\text { standard of } 150 \mu \mathrm{g} / \mathrm{m}^{3} \\
\text { Highest (night-time } 12 \text {-hour } \\
\text { average) } \mathrm{PM}_{2.5} 195 \mu \mathrm{g} / \mathrm{m}^{3} \\
\end{array}$ & $\begin{array}{l}\text { Decreased lung function in asthmatics } \\
\text { associated with an increase of } 10 \mu \mathrm{g} / \mathrm{m}^{3} \text { in } \mathrm{PM}_{2.5}\end{array}$ & Koenig et al. (1993)* \\
\hline $\begin{array}{l}\text { Seattle, Washington, } \\
\text { US; 1989-1990 }\end{array}$ & $\begin{array}{l}\text { Population study, all } \\
\text { ages }\end{array}$ & $\begin{array}{l}\text { Daily emergency room } \\
\text { visits }\end{array}$ & $\begin{array}{l}\text { 24-h PM } 10 \text { 6-103 } \mu \mathrm{g} / \mathrm{m}^{3} \text {, mean } 30 \\
\mu \mathrm{g} / \mathrm{m}^{3}\end{array}$ & $\begin{array}{l}\text { Increased asthma visits, } \mathrm{RR}=112\left(30 \mu \mathrm{g} / \mathrm{m}^{3} \mathrm{PM}_{10}\right. \\
\text { increase) }\end{array}$ & Schwartz et al. (1993)* \\
\hline $\begin{array}{l}\text { Santa Clara County, } \\
\text { US; winter seasons } \\
1988 \text { and 1989-1991 } \\
\text { and } 1992\end{array}$ & $\begin{array}{l}\text { Population study, all } \\
\text { ages }\end{array}$ & $\begin{array}{l}\text { Daily asthma } \\
\text { emergency room visits }\end{array}$ & $\begin{array}{l}\text { 24-h PM } 109-165 \mu \mathrm{g} / \mathrm{m}^{3}, \text { mean } 61 \\
\mu \mathrm{g} / \mathrm{m}^{3}\end{array}$ & $\begin{array}{l}\text { Increased asthma visits, } \mathrm{RR}=143 \text { (low } \\
\text { temperature) and } 1 \mathrm{ll} \text { (mean temperature) for } 60 \\
\mu \mathrm{g} / \mathrm{m}^{3} \mathrm{PM}_{10} \text { increase }\end{array}$ & Lipsett et al. (1997)* \\
\hline $\begin{array}{l}\text { Christchurch, New } \\
\text { Zealand; } 3 \text { months } \\
\text { during winter } 1994\end{array}$ & $\begin{array}{l}\text { Panel study, subjects } \\
\text { with COPD aged }>55 \\
\text { years }\end{array}$ & Respiratory symptoms & $\begin{array}{l}\text { 24-h } \mathrm{PM}_{10} \text { generally well below the } \\
\mathrm{NZ} \text { air quality guideline of } 120 \\
\mu \mathrm{g} / \mathrm{m}^{3}\end{array}$ & $\begin{array}{l}\text { Increase in chest symptoms, } \mathrm{RR}=138\left(35 \mu \mathrm{g} / \mathrm{m}^{3}\right. \\
\mathrm{PM}_{10} \text { increase); increased inhaler and nebulizer } \\
\text { use, } \mathrm{RR}=142 \text { and } 2.81\left(10 \mu \mathrm{g} / \mathrm{m}^{3} \mathrm{NO}_{2} \text { increase) }\right.\end{array}$ & Harré et al. (1997)* \\
\hline $\begin{array}{l}\text { Port Alberni, British } \\
\text { Columbia, Canada; } \\
\text { 1990-92 }\end{array}$ & $\begin{array}{l}\text { Panel study, asthmatic } \\
\text { and non-asthmatic } \\
\text { children }(n=206)\end{array}$ & Respiratory symptoms & $\begin{array}{l}\text { 24-h PM } \mathrm{PM}_{10} \text { O-159 } \mu \mathrm{g} / \mathrm{m}^{3}, \text { mean } 27 \\
\mu \mathrm{g} / \mathrm{m}^{3}\end{array}$ & $\begin{array}{l}\text { For asthmatics, increased cough, } \mathrm{RR}=108 \text { ( } 10 \\
\mu \mathrm{g} / \mathrm{m}^{3} \mathrm{PM}_{10} \text { increase); and reduction of } \mathrm{PEF}\end{array}$ & Vedal et al. (1998)* \\
\hline $\begin{array}{l}\text { Seattle, Washington, } \\
\text { US; 1995-1996 }\end{array}$ & $\begin{array}{l}\text { Population study, } \\
\text { persons }<18 \text { years }\end{array}$ & $\begin{array}{l}\text { Daily asthma hospital } \\
\text { admissions }\end{array}$ & $\begin{array}{l}\text { 24-h PM }{ }_{10} 8-70 \mu \mathrm{g} / \mathrm{m}^{3} \text {, mean } 22 \\
\mu \mathrm{g} / \mathrm{m}^{3} \\
24-\mathrm{h} \mathrm{PM}_{2.5}, \text { mean } 12 \mu \mathrm{g} / \mathrm{m}^{3}\end{array}$ & $\begin{array}{l}\text { Increased asthma hospital admissions; } \mathrm{RR}=114 \\
\left(12 \mu \mathrm{g} / \mathrm{m}^{3} \mathrm{PM}{ }_{10} \text { increase), } \mathrm{RR}=115\left(11 \mu \mathrm{g} / \mathrm{m}^{3}\right.\right. \\
\mathrm{PM}_{2.5} \text { increase) }\end{array}$ & Norris et al. (1999)* \\
\hline $\begin{array}{l}\text { Seattle, Washington, } \\
\text { US; 1987-1994 }\end{array}$ & $\begin{array}{l}\text { Population study, all } \\
\text { ages }<65\end{array}$ & $\begin{array}{l}\text { Daily hospital } \\
\text { admissions for } \\
\text { asthma } \\
\end{array}$ & $\begin{array}{l}\text { 24-h mean } \mathrm{PM}_{10} 315 \mu \mathrm{g} / \mathrm{m}^{3} ; \mathrm{PM}_{2.5} \\
16.7 \mu \mathrm{g} / \mathrm{m}^{3}\end{array}$ & $\begin{array}{l}\text { Increase in asthma hospital admissions; } \mathrm{RR}=105 \\
\left(19 \mu \mathrm{g} / \mathrm{m}^{3} \mathrm{PM}_{10} \text { increase), } \mathrm{RR}=104\left(12 \mu \mathrm{g} / \mathrm{m}^{3}\right.\right. \\
\left.\mathrm{PM}_{2.5} \text { increase }\right)\end{array}$ & $\begin{array}{l}\text { Sheppard et al. } \\
\text { (1999)* }\end{array}$ \\
\hline $\begin{array}{l}\text { Seattle, Washington, } \\
\text { US; 1993-1995 }\end{array}$ & $\begin{array}{l}\text { Panel study, } 133 \\
\text { children, } 5-13 \text { years of } \\
\text { age }\end{array}$ & Asthma symptoms & $\begin{array}{l}\text { 24-h } \mathrm{PM}_{10} 8-86 \mu \mathrm{g} / \mathrm{m}^{3} \text {, mean } 25 \\
\mu \mathrm{g} / \mathrm{m}^{3} 24-\mathrm{h} \mathrm{PM}_{1} 2-62 \mu \mathrm{g} / \mathrm{m}^{3} \text {, mean } \\
10.4 \mu \mathrm{g} / \mathrm{m}^{3}\end{array}$ & $\begin{array}{l}\text { Increased asthma symptoms; } \mathrm{RR}=117\left(10 \mu \mathrm{g} / \mathrm{m}^{3}\right. \\
\mathrm{PM}_{1} \text { increase), RR }=111\left(10 \mu \mathrm{g} / \mathrm{m}^{3} \mathrm{PM}_{10} \text { increase) }\right.\end{array}$ & Yu et al. (2000)* \\
\hline $\begin{array}{l}\text { Spokane, } \\
\text { Washington,US } \\
\text { 1995-2001 }\end{array}$ & $\begin{array}{l}\text { Population study, all } \\
\text { ages }\end{array}$ & $\begin{array}{l}\text { Cardiac hospital } \\
\text { admissions; } \\
\text { respiratory emergency } \\
\text { department visits }\end{array}$ & $\begin{array}{l}\text { 24-h } \mathrm{PM}_{2.5} 2.9-25 \mu \mathrm{g} / \mathrm{m}^{3}(95 \% \mathrm{Cl}) \\
\text { mean } 10.6 \mu \mathrm{g} / \mathrm{m}^{3} \\
\text { 24-h Total carbon } 14-9.4 \mu \mathrm{g} / \mathrm{m}^{3} \\
(95 \% \mathrm{Cl}) \text {, mean } 4.6 \mu \mathrm{g} / \mathrm{m}^{3}\end{array}$ & $\begin{array}{l}\text { Increased respiratory emergency departments } \\
\text { visits; } \mathrm{RR}=1013\left(7.7 \mu \mathrm{g} / \mathrm{m}^{3} \text { increase in } \mathrm{PM}_{2.5}\right) \\
\text { Increased respiratory emergency departments } \\
\text { visits; } \mathrm{RR}=1.023\left(3.0 \mu \mathrm{g} / \mathrm{m}^{3} \text { increase in total }\right. \\
\text { carbon) }\end{array}$ & $\begin{array}{l}\text { Schreuder et al. } \\
\text { (2006) }\end{array}$ \\
\hline $\begin{array}{l}\text { Christchurch, New } \\
\text { Zealand; 1988-1993 }\end{array}$ & $\begin{array}{l}\text { Population study, all } \\
\text { ages }\end{array}$ & Daily mortality & $\begin{array}{l}\text { 24-h PM } 100-187 \mu \mathrm{g} / \mathrm{m}^{3}, \text { mean } 28 \\
\mu \mathrm{g} / \mathrm{m}^{3}\end{array}$ & \begin{tabular}{|l} 
Increased mortality (all ages): \\
$\mathrm{RR}=101$ (all causes), $\mathrm{RR}=104$ (respiratory \\
causes) $\left(10 \mu \mathrm{g} / \mathrm{m}^{3} \mathrm{PM}_{10}\right.$ increase)
\end{tabular} & Hales et al. (2000)* \\
\hline
\end{tabular}

* The nine studies included in the review of Boman et al. (2003) discussed below.

COPD: Chronic Obstructive Pulmonary Disease

PEF: Peak Expiratory Flow 
Schreuder et al. (2006) used source appointment techniques in order to separate different sources of PM in the state of $W$ ashington during the period 1995-2001. T otal carbon and arsenic had high correlations with vegetative burning (arsenic due to burning af arsenic treated wood) while other markers were correlated to motor vehicles $(\mathrm{Zn})$ and airborne soil (Si). Vegetative burning contributed to about half of the total $\mathrm{PM}_{2.5}$ level. T he association between the different markers and hospital admissions for cardiac diseases and emergency departments visits for respiratory diseases were analysed. The rate of respiratory emergency department visits increased $2 \%$ for a $3.0 \mu \mathrm{g} / \mathrm{m}^{3}$ interquartile range change in total carbon $(1.023,95 \% \mathrm{CI} 1.009-1.038)$ at a lag of one day. For total $\mathrm{PM}_{2.5}$, an interquartile increase of $7.7 \mathrm{PM}_{2.5}$ was associated with an increase in respiratory department visits of $1.3 \%(R R=$ $1.013,95 \% \mathrm{Cl} 0.999-1.025)$. T he results suggest that vegetative burning is associated with acute respiratory events.

Vedal et al. (1998) have studied the acute effects of ambient particles in 206 asthmatic and non-asthmatic children living on the west coast of $V$ ancouver I sland. T he children, aged 6-13 years, were followed for up to 18 months with twice daily measurements of peak expiratory flow (PEF) and daily recording of symptoms. D ata on $\mathrm{PM}_{10}$ were available from two monitoring sites, and the daily mean $\mathrm{PM}_{10}$ concentration was $27 \mu \mathrm{g} / \mathrm{m}^{3}$ (range $0-159 \mu \mathrm{g} / \mathrm{m}^{3}$ ). Increases in $\mathrm{PM}_{10}$ concentrations were associated with reductions in PEF and increased reporting of cough, phlegm production, and sore throat. For asthmatics, an increase of $10 \mu \mathrm{g} / \mathrm{m}^{3}$ in $\mathrm{PM}_{10}$ was associated with a reduction of PEF by 0.55 $\mathrm{I} / \mathrm{min}(95 \% \mathrm{Cl}, 0.06-1.05)$ and increased odds of reported cough by $8 \%$ (95\% $\mathrm{CI}, 0-16 \%)$. The authors concluded that children with asthma are more susceptible to these effects than other children.

T wo time series studies have been conducted in Santa Clara C ounty, C alifornia, an area in which wood smoke is the single largest contributor to winter $\mathrm{PM}_{10}$, accounting for approximately $45 \%$ of winter $\mathrm{PM}_{10}$ ( $F$ airley 1990 , Lipsett et al. 1997). Particulate levels are highest during the winter in this area.

T he first study was one of the initial mortality time series studies, which indicated an association between relatively low $\mathrm{PM}_{10}$ levels and increased daily mortality (Fairley 1990).

In the second study, L ipsett et al. (1997) found a consistent relationship of asthma emergency room visits in Santa Clara County and winter $\mathrm{PM}_{10}$ during the winter seasons ( $N$ ovember-January) 1988-89 through 1991-92. T he mean $P M_{10}$ concentration during the study was $61 \mu \mathrm{g} / \mathrm{m}^{3}\left(9-165 \mu \mathrm{g} / \mathrm{m}^{3}\right)$.

Specifically, a $10 \mu \mathrm{g} / \mathrm{m}^{3}$ increase in $\mathrm{PM}_{10}$ was associated with a 2-6 \% increase in asthma emergency room visits. T hese results demonstrate an association between ambient wintertime $\mathrm{PM}_{10}$ and increased daily mortality and exacerbations of asthma in an area where one of the principal sources of PM ${ }_{10}$ is residential wood smoke.

Particulate air pollution was found to be associated with increased daily mortality in Christchurch, $\mathrm{N}$ ew Zealand (Hales et al. 2000). D ue to the local topography, Christchurch experiences temperature inversion conditions in winter. Pollutants, especially from household fires, then accumulate over most of the city. In summer, temperatures rise rapidly during north westerly wind conditions and can exceed $35^{\circ} \mathrm{C}$, leading to heat stress. $\mathrm{H}$ ourly $\mathrm{SO}_{2}, \mathrm{NO}_{x^{\prime}} \mathrm{CO}$ and $\mathrm{PM}_{10}$ data were available from a representative, centrally located site for June 1988 - D ecember 1993. An increase in $\mathrm{PM}_{10}$ of $10 \mathrm{ug} / \mathrm{m}^{3}$ was associated (after a lag of one day) with a $1 \%(0.5-2.2 \%)$ increase in all-cause mortality 
and a 4\% (1.5-5.9\%) increase in respiratory mortality. T here were no statistically significant associations between mortality from cardiovascular causes and $\mathrm{PM}_{10}$. Furthermore, there were no statistically significant associations between mortality and other air pollution variables.

$\mathrm{H}$ arré et al. (1997) investigated respiratory symptoms and peak expiratory flow (PEF) in subjects with chronic obstructive pulmonary disease (COPD) living in $\mathrm{C}$ hristchurch, $\mathrm{N}$ ew Zealand. Forty subjects aged over 55 years were studied for three months during the winter 1994. $\mathrm{D}$ ata on $\mathrm{PM}_{10}, \mathrm{~N} \mathrm{O}_{2}, \mathrm{SO}_{2}$ and $\mathrm{CO}$ were measured at one monitoring site. T he mean daily $\mathrm{PM}_{10}$ level was generally below the N Z air quality guideline of $120 \mu \mathrm{g} / \mathrm{m}^{3}$ (the guideline was exceeded five times). An increase in $P M_{10}$ concentration of $35 \mu \mathrm{g} / \mathrm{m}^{3}$ was associated with an increase in relative risk of $1.38(95 \% \mathrm{Cl} 1.13-1.79)$ in night-time chest symptoms. A rise in $\mathrm{N} \mathrm{O}_{2}$ concentration of $10 \mu \mathrm{g} / \mathrm{m}^{3}$ was associated with increased use of reliever inhaler ( $R \mathrm{R} 1.42,95 \% \mathrm{CI}$ 1.13-1.79). $\mathrm{No}$ association was found between PEF and any of the pollution variables.

A Swedish research programme "Biobränsle-H älsa-M iljö" ( "Biomass burning-H ealth-Environment") consisting of more than 25 different projects during the period 2000-2003 has been reported in a summary report, BH M (2003).

O ne of the BHM studies examined the association between hospital admissions due to respiratory diseases and levels of soot and $\mathrm{PM}_{2.5}$ in $\mathrm{L}$ ycksele - a town with a high concentration of residential wood burning. D uring five winter periods a significant association was found between 24-hour soot levels and asthma hospital admissions on the same day. F or daily PM ${ }_{2.5}$ levels (a parameter less associated with wood burning compared to soot), a positive and significant association was found for hospital admissions from chronic obstructive pulmonary diseases on the same and the following day. (BH M 2003).

In a panel study in L ycksele, 26 persons with asthma kept a dairy concerning respiratory symptoms for 10 weeks. An association was found between the increase in asthma symptoms and increases in soot as well as in $\mathrm{PM}_{2.5}$-levels. In another panel study in L ycksele, 46 persons were followed during January to $\mathrm{M}$ arch 2001. Blood samples were taken on days with expected high air pollution and analysed for fibrinogen and C-reactive protein, i.e., inflammatory markers in relation to cardiovascular diseases. $\mathrm{No}$ association could be found for the various air pollution measures and the levels of the inflammatory markers. However, an effect of the pollution could not be ruled out as it was concluded that the power of the study was too low due to small variation in air pollution in combination with the small size of the study group. (BH M 2003).

Johanson et al. (2004) sent out questionnaires to 1250 people in four small towns with a high concentration of residential wood burning. T he response rate was $74 \%$ and of these, $28 \%$ used wood / pellets as the dominant heating source. T he average heating time for the respondents was 25 hours per week during winter. In total, $19 \%$ found that air pollution from wood burning was the greatest disadvantage by living in the area. Fifteen percent reported discomfort due to smell especially in winter and $22 \%$ reported nuisance due to soot/dust. A mong the 10\% who had asthma, there was an increased rate of discomfort from smell, nuisance from soot/dust, and difficulties in breathing. 


\subsection{Review by Boman et al. (2003)}

Boman et al. (2003) have reviewed the scientific literature concerning adverse health effects from ambient air pollution in relation to residential wood combustion in modern society and attempted to extract quantifications for the associations. Based on a literature search, references that fulfilled the following inclusion criteria were included for further analysis: (1) an epidemiological study, (2) concerning adverse health effects from ambient air pollution concentrations (not indoor or occupational exposure), (3) from settings in which residential wood combustion was mentioned as an important air pollution source, (4) full scientific paper published in English. These selection criteria resulted in nine papers, which were either population studies $(N=5)$ or panel studies $(\mathrm{N}=4)$. T he studies, marked with an asterix, are summarised in T able 6.

F our different geographic areas have been studied: Seattle, W ashington, and Santa Clara C ounty, C alifornia in the U nited States; Port A Iberni, B ritish Columbia, in Canada; and Christchurch in $\mathrm{N}$ ew Zealand. Five of the studies were conducted in the Seattle metropolitan area and two in C hristchurch.

Only a few studies were found in which residential wood combustion was identified as a (or the) major source of ambient air pollution. One reason can be that wood smoke emissions are often the dominating air pollution only in rural areas and small towns and that there are difficulties associated with studying sparsely populated areas using epidemiological methods. H owever, of the four studied areas, only Port Alberni can be considered a small rural town, while the other three are large cities. Of the few existing studies, only in studies from two areas (Seattle and Santa Clara C ounty), does there seem to exist some published material that confirms that residential wood combustion was a major source of ambient PM in the areas.

D ifferent exposure assessment parameters were used in the included papers. The most common indicators were $\mathrm{PM}_{10}$ ( 8 studies), $\mathrm{SO}_{2}$ ( 5 studies), $\mathrm{CO}$ ( 5 studies), and $\mathrm{NOx} \mathrm{N} \mathrm{O}_{2}$ (4 studies). $\mathrm{PM}_{2.5}, \mathrm{PM}_{1}$, and ozone were only occasionally used.

T he nine included studies focused on the effects of short-term exposure on asthma, respiratory symptoms, mortality, and lung function. All of the studies reported positive significant associations between variations in air pollution levels and adverse health outcomes. PM was the parameter that showed the most frequent and most obvious associations with the addressed health effects: in all the studies, significant positive associations were found when $\mathrm{PM}_{10}, \mathrm{PM}_{2.5}$, and $\mathrm{PM}_{1}$ were used as an indicator of air pollution. $O$ verall, the relative risk ( RR) between an increase in ambient $P M_{10}$ with 10 $\mu \mathrm{g} / \mathrm{m}^{3}$ and different health outcomes varied between 1.018 and 1.117. CO showed significant positive associations with the addressed effects in 3 of the four studies, and $\mathrm{NO}_{2}$ in one of the four studies. Associations with $\mathrm{SO}_{2}$ or $\mathrm{O}_{3}$ were not found in any study. $\mathrm{N}$ o relevant long-term exposure studies with health outcomes like cardiopulmonary mortality, lung cancer, or chronic bronchitis were found.

5.1.2.2.2 Comparison of PM from wood smoke and PM in the general environment (Boman et al. 2003) 
Boman et al. (2003) also compared the results from the studies in which residential wood combustion was mentioned as an important air pollution source with the estimations for the association between PM and health effects in the general environment. F or these comparisons, they used a dose-response relationship from WHO (2000), a "state of the art" review (Pope et al. 1999), and a recent European study (Atkinson et al. 2001). T hey compared the results from the five wood smoke studies with associations between increases in ambient PM ${ }_{10}$ and asthma symptoms, hospital admissions, and emergency room visits, together with one study with associations for cough. Although recognising the difficulties in comparing the results from different studies due to differences in the statistical analyses and presentation of the results, the comparison gives some indications of the relations, see Figure 3. All the included studies showed significant positive associations, and, in comparison with the estimations of WHO and other "state of the art" estimations concerning ambient PM and health, the effects (RR) are even stronger in the studies in which residential wood combustion is considered a major PM source, especially for children. T hus there seems to be no reason to assume that the health effects associated with PM in areas polluted with wood smoke are weaker than elsewhere.

There are not enough data to allow for a comparison of different PM indicators, e.g., if $\mathrm{PM}_{10}$ is better than $\mathrm{PM}_{2.5}$ as an indicator.

Figure 3. Rel ative risks for differ ent morbidity outcomes in association with a 10 $\mathrm{\mu g} / \mathrm{m}^{3}$ increase in $\mathrm{PM}_{10}$ with $95 \%$ confidence inter val s as er ror bar s. The studies in which wood smoke was consider ed a major air pollution source are shown by closed col umns, and the comparison estimates ar e represented by o pen column S (APHEA2: European study by Atkinson et al . 2001). Reproduced from Boman et al . (2003).

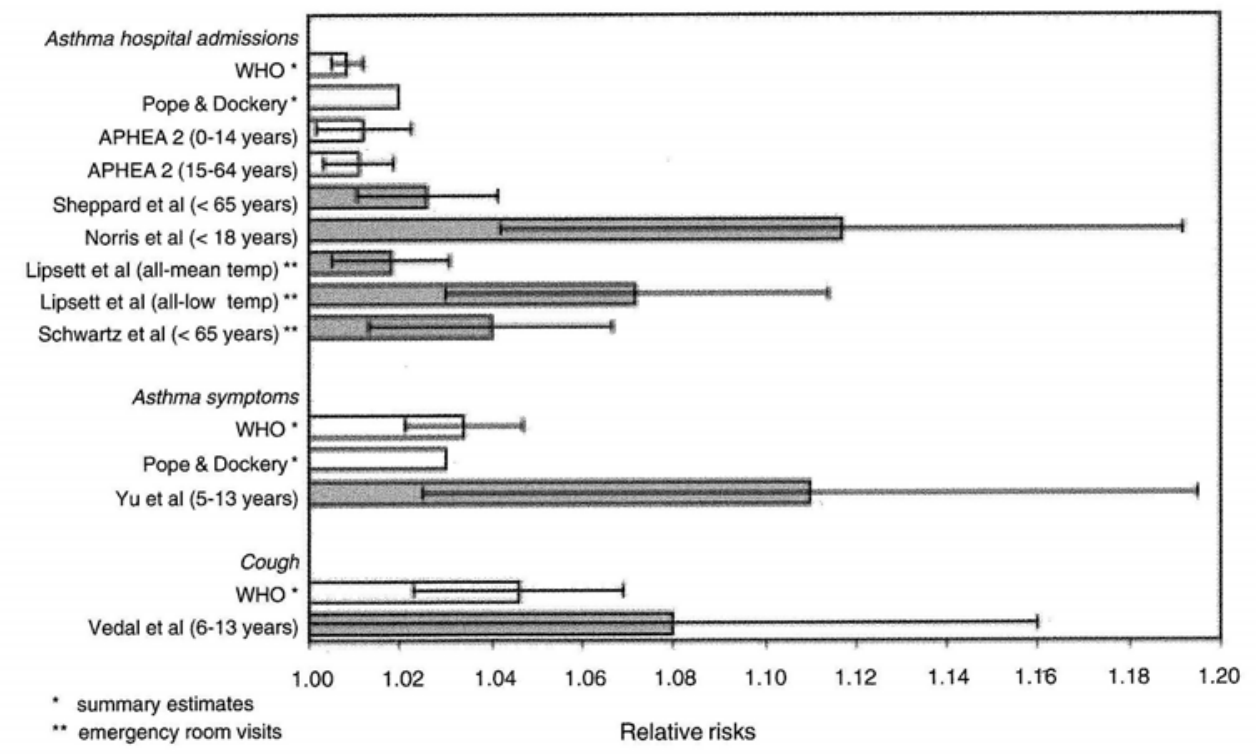

In most of the studied areas, residential wood combustion was expected to be an important source of ambient PM mainly during the winter season. Several of the studies used observation periods of years, including months in which wood smoke pollution was not a major factor. T wo of the studies reported seasonal effect estimations. O ne study (Vedal et al. 1998) reported that the effect estimates for the autumn-winter period were essentially identical with those for the spring period. T he other study (Sheppard et al. 1999) reported season-specific estimates, which were negative for summer, but were higher 
for spring and fall than for the winter season. T he authors suggested that their results indicate a persistent effect of pollution from automobiles on health. In the study by Schwartz et al. (1993), the effect estimations were based on the whole study period (1 year), and they suggested that the high PM concentrations in association with asthma visits during the winter reflect, in large part, the toxicity of wood smoke. H owever, they also commented on the fact that these associations continue even at relatively low PM concentrations, and, therefore, wood smoke is probably not the only contributing factor.

\subsection{Review by $\mathrm{N}$ aeher et al. (2007)}

$N$ aeher et al. (2007) conducted recently a detailed overall review regarding wood smoke and health effects. T his review, which is based on an extended list of references, confirms the overall picture presented by Bomann et al. (2003) as well as the present report. T he authors concluded that there is a large a growing body of evidence that wood smoke cause acute and chronic illness. Although the health effects should be considered to be linked to the whole complex mixture of components in the wood smoke there is insufficient data to regulate otherwise than on single components. In that respect fine particulate matter is considered the most relevant parameter. Further data is needed in order to clarify whether toxicity and risk associated to wood smoke particles should be considered otherwise than ambient particulate matter in general.

\subsubsection{Other settings with wood smoke exposure}

A round $50 \%$ of people, almost all in developing countries rely on coal and biomass in the form of wood, dung and crop residues for domestic energy (Bruce et al. 2000). T hese materials are typically burned in simple stoves with very incomplete combustion. Consequently, women and young children are exposed to high levels of indoor air pollution every day. There is consistent evidence that indoor air pollution increases the risk of chronic obstructive pulmonary disease and of acute respiratory infections (ARI) in childhood, the most important cause of death among children less than 5 years of age in developing countries. Evidence also exists of associations with low birth weight, increased infant and peri-natal mortality, pulmonary tuberculosis, and nasopharyngeal and laryngeal cancer. Conflicting evidence exists with regard to asthma. All studies are observational and very few have measured exposure directly, while a substantial proportion have not dealt with confounding. As a result, risk estimates are poorly quantified and may be biased.

A number of studies have reported associations of adverse health impacts with use of biomass fuels, although few have directly measured exposure. T he studies are described below and summarised in T able 7.

A case-control study conducted in Zimbabwe found a significant association between lower respiratory disease and exposure to atmospheric wood smoke pollution in young children. D ata from 244 cases was compared with information from 500 children seen at the local well baby clinic. Air sampling within the kitchens of 40 children indicated very high concentrations (546$1998 \mathrm{ug} / \mathrm{m}^{3}$ ) of respirable particulates. Blood C OH b was determined for 170 out of 244 children confirming that they did experience smoke inhalation. (Collings et al. 1990). 
A case-control study of $\mathrm{M}$ exican women reported an increased risk of chronic bronchitis and chronic airway obstruction (CAO) associated with cooking with traditional wood stoves (Perez-Padilla et al. 1996). C rude odds ratios for wood smoke exposure were $3.9(95 \% \mathrm{Cl}, 2.0-7.6)$ for chronic bronchitis only, 9.7 (95\% Cl, 3.7-27) for chronic bronchitis plus C AO, and $1.8(95 \% \mathrm{Cl}, 0.7$ 4.7) for CAO only. The risk of chronic bronchitis alone and chronic bronchitis with CAO increased linearly with hour-years (years of exposure multiplied by average hours of exposure per day) of cooking with a wood stove. T he median duration of wood smoke exposure were 25 and 28 years for the chronic bronchitis and chronic bronchitis/CAO disease groups, respectively. T he median time of wood smoke exposure was 3 hours per day in the case groups.

Table 7. Studies with indo or exposure to wood smokefrom cooking (high l evel)

\begin{tabular}{|l|l|l|l|l|}
\hline Population & Endpoints & $\begin{array}{l}\text { Exposure } \\
\text { assessment }\end{array}$ & Results & Reference \\
\hline $\begin{array}{l}\text { Children in } \\
\text { Zimbabwe }\end{array}$ & $\begin{array}{l}\text { Respiratory } \\
\text { illness }\end{array}$ & $\begin{array}{l}\text { Respirable particles } \\
546-1998 \mu \mathrm{g} / \mathrm{m}^{3}\end{array}$ & $\begin{array}{l}\text { Increased lower } \\
\text { respiratory illness with } \\
\text { wood smoke exposure }\end{array}$ & $\begin{array}{l}\text { Collings et al. } \\
\text { (1990) }\end{array}$ \\
\hline $\begin{array}{l}\text { Adult women in } \\
\text { Mexico }\end{array}$ & COPD & $\mathrm{Nd}$ & $\begin{array}{l}\text { COPD in non-smoking } \\
\text { women }\end{array}$ & $\begin{array}{l}\text { Perez-Padilla et al. } \\
\text { (1996) }\end{array}$ \\
\hline $\begin{array}{l}\text { Adult women in } \\
\text { Mozambique }\end{array}$ & Symptoms & $\mathrm{PM}_{10} 1200 \mu \mathrm{g} / \mathrm{m}^{3}$ & $\begin{array}{l}\text { Increased cough } \\
\text { symptoms in wood smoke } \\
\text { exposed group (relative to } \\
\text { charcoal, gas, electric) }\end{array}$ & Ellegard (1996) \\
\hline $\begin{array}{l}\text { Adult women in } \\
\text { Colombia }\end{array}$ & COPD & $\mathrm{Nd}$ & $\begin{array}{l}\text { COPD in non-smoking } \\
\text { women }\end{array}$ & $\begin{array}{l}\text { Dennis et al. } \\
\text { (1996) }\end{array}$ \\
\hline $\begin{array}{l}\text { Children in } \\
\text { Guatemala }\end{array}$ & $\begin{array}{l}\text { Asthma } \\
\text { symptoms }\end{array}$ & $\mathrm{Nd}$ & $\begin{array}{l}\text { Increase in asthma } \\
\text { symptoms in children } \\
\text { with open wood fire } \\
\text { compared to stoves with } \\
\text { chimney }\end{array}$ & Schei et al. (2004) \\
\hline $\begin{array}{l}\text { Children in } \\
\text { Calcutta }\end{array}$ & Pneumonia & Nd & $\begin{array}{l}\text { Increased risk of } \\
\text { pneumonia }\end{array}$ & $\begin{array}{l}\text { Mahalanabis et al. } \\
\text { (2002) }\end{array}$ \\
\hline $\begin{array}{l}\text { Women } \\
\text { Spain }\end{array}$ & COPD & $\begin{array}{l}\text { Years of exposure } \\
\text { from indoor wood or } \\
\text { charcoal smoke }\end{array}$ & $\begin{array}{l}\text { Increased risk of COPD } \\
\text { hospitalisation }\end{array}$ & $\begin{array}{l}\text { Orozco-Levi et al. } \\
\text { (2006) }\end{array}$ \\
\hline
\end{tabular}

COPD: Chronic Obstructive Pulmonary Disease $\mathrm{N}$ d: not determined

T he association between exposure to air pollution from cooking fuels and health aspects was studied in M aputo, M ozambique (Ellegard 1996). Personal air samples for particulate (roughly equivalent to $\mathrm{PM}_{10}$ ) were collected when four types of fuels (wood, charcoal, electricity, and liquefied petroleum gas) were used for cooking. Wood users were exposed to significantly higher levels of particulate pollution during cooking time $\left(1200 \mu \mathrm{g} / \mathrm{m}^{3}\right)$ than charcoal users $\left(540 \mu \mathrm{g} / \mathrm{m}^{3}\right.$ ) and users of modern fuels (petroleum gas and electricity) (200$380 \mu \mathrm{g} / \mathrm{m}^{3}$ ). W ood users were found to have significantly more cough symptoms than other groups. T his association remained significant when controlling for a large number of environmental variables. T here was no difference in cough symptoms between charcoal users and users of modern fuels. Other respiratory symptoms such as dyspnoea, wheezing, and inhalation and exhalation difficulties were not associated with wood use.

A case-control study conducted in Colombia identified a similar risk of obstructive airways disease (OAD) in women who cooked with biomass 
( $D$ ennis et al. 1996). U nivariate analysis showed that tobacco use ( $O R=$ 2.22; $p<0.01)$; wood use for cooking ( $O R=3.43 ; p<0.001)$ and passive smoking $(O R=2.05 ; p=0.01$ ) was associated with $O A D$. The adjusted odds ratio for obstructive airways disease and wood use (adjusted for smoking, gasoline and passive smoke exposure, age and hospital) was 3.92. T he mean number of years of wood smoke exposure was 33 in the cases. The authors suggested that wood smoke exposure in these elderly women was associated with the development of OAD and may help explain around $50 \%$ of all OAD cases.

Schei et al. (2004) studied the prevalence and severity of asthma in relation to indoor cooking on open wood fires in W estern G uatemalan Highlands. T he mothers of 1058 children aged 4-6 years were interviewed using a standardised questionnaire. T he authors found that the asthma prevalence among children in $\mathrm{G}$ uatemala is low compared to other populations in $\mathrm{L}$ atin A merica. T he prevalence of all the symptoms of asthma was higher in children from households that used open fires compared to improved stoves with chimneys. In a logistic regression model, use of open fire for cooking was a significant risk factor for a number of asthma symptoms, with odds ratios varying from 2.0 to 3.5 .

Pneumonia was found to be associated with the use of solid fuel for cooking (e.g. coal, wood, dung) in a case-control study of children in Calcutta ( $M$ ahalanabis et al. 2002). C ases were 127 children aged 2-35 months. Solid fuel use was associated with risk of pneumonia in a logistic regression model after adjusting for confounding ( $\mathrm{OR}=3.97, \mathrm{Cl}=2.00-7.88$ ).

B ruce et al. (2000) reviewed the epidemiological evidence for the health effects of indoor smoke from solid fuels and concluded that, despite some methodological limitations, the epidemiological studies together with experimental evidence and pathogenesis provide compelling evidence of causality for acute respiratory infections and chronic obstructive pulmonary disease.

Smith et al. (2000) reviewed the details of biologic mechanisms and epidemiological studies on indoor air pollution and childhood acute respiratory infections (ARI). T he authors concluded that the association of smoke from biomass fuels with ARI should be considered as causal, although the quantitative risk has not been fully characterised. Risk estimates from individual studies are imprecise because of relatively small sample sizes and misclassification of exposure and outcome. G iven the imprecision and uncertainty in characterising the risk of biomass smoke exposure, quantitative risk assessments cannot be offered with great confidence.

O rozco-L evi et al. (2006) found a strong association between years of wood or charcoal smoke exposure from cooking or heating and increased risk for hospitalisation for chronic obstructive pulmonary disease (COPD) among 120 Spanish women during the period 2001-2003. Wood or charcoal alone independently increased the risk of C OPD with odds ratios (OR) of 1.8 (95\% interval: 0.6-6.0) and 1.5 (95\% interval: $0.5-4.6)$, respectively, but only the combination of wood and charcoal was statistically significant (OR 4.5, 95\% interval: 1.4-14.2). 


\subsubsection{Summary, non-cancer health effects}

T he association of particulate air pollution (PM ) with adverse health effects has long been recognised, especially in relation to respiratory and cardiovascular diseases. The experience is mainly based on epidemiological studies (cohort studies and time-series studies). A limitation with both study designs is the exposure characterisation, which is usually based on data from a single monitoring site in the area, and assumed to be representative for all individuals in the area. A nother limitation is that most of the exposure information is on fine particles $\left(\mathrm{PM}_{2.5}\right)$, or the sum of fine and coarse particles $\left(P M_{10}\right)$, whereas the information on ultrafine particles is limited.

$\mathrm{N}$ umerous studies have demonstrated that urban particulate air pollution is associated with increased mortality, primarily in the elderly and in individuals with pre-existing respiratory and/or cardiac diseases.

Several time-series studies in USA and Europe are available. A meta-analysis showed that an increase of $10 \mu \mathrm{g} / \mathrm{m}^{3} \mathrm{PM}_{10}$ was associated with a $0.6 \%$ increase in total mortality, a $1.3 \%$ increase in respiratory related deaths, and a $0.9 \%$ increase in cardiovascular deaths in a city area in the first days after the PM ${ }_{10}$ increase (Anderson et al. 2004); if the observation time was extended for 40 days, the increase in total mortality was $1 \%$ (Zanobetti et al. 2003). A study in the $G$ erman city Ehrfuhrt indicated that the effect of ultrafine particles on death due to cardiac and respiratory disease was comparable to the effect of $\mathrm{PM}_{2.5}$ and $\mathrm{PM}_{10}$ (W ichmann et al. 2000). In a recently published update of this study (Stölzel et al. 2006), a significant association between total mortality and cardio-respiratory mortality and the number concentrations of ultrafine particles was found whereas the increased mortality in relation to particle mass $\left(\mathrm{PM}_{10}\right.$ ) did not reach a significant response. A nother European study (in A msterdam, Ehrfuhrt and $\mathrm{H}$ elsinki) reported that effects on cardiac and respiratory disease correlated better with $\mathrm{PM}_{2.5}$ than with the ultrafine particles (de $\mathrm{H}$ artog et al. 2003, Pekkanen et al. 2002).

A few cohort studies are available at present. T he most recent A merican cohort study (Pope et al. 2002) revealed a clear and significant association between mortality and the $\mathrm{PM}_{2.5}$ level as the mortality increased with $4 \%$ per $10 \mu \mathrm{g} / \mathrm{m}^{3} \mathrm{PM}_{2.5}$ in 1979-83 and with $6 \%$ per $10 \mu \mathrm{g} / \mathrm{m}^{3} \mathrm{PM}_{2.5}$ in 1999-2000; mortality caused by heart/lung disease was increased with $9 \%$ per $10 \mu \mathrm{g} / \mathrm{m}^{3}$ $\mathrm{PM}_{2.5}$. A recent study (Jerret et al. 2005) on a subset ( $L$ os Angeles area) of the A merican cohort has reported a $10 \mu \mathrm{g} / \mathrm{m}^{3}$ increase in the annual $\mathrm{PM}_{2.5}$ level to be associated with an increase in mortality of $17 \%$. The corresponding increase in ischaemic heart disease was $38 \%$ and for lung cancer $46 \%$. T hus, the study on the subset of the A merican cohort found an increase in mortality that was three times higher than that reported for the entire A merican cohort in the period 1999-2000. T he increase in the subset study was considered to be due to a more accurate exposure assessment than in the prior studies. The authors also suggested that a higher contribution of traffic PM in the L os A ngeles area might have resulted in the higher increased mortality.

A recently published follow-up of the D ockery et al. (1993) six cities study found an increase of $16 \%$ in the overall mortality to be associated with each 10 $\mu \mathrm{g} / \mathrm{m}^{3} \mathrm{PM}_{2.5}$ as an overall mean during the period, or an increase of $14 \%$ in relation to the annual mean of $\mathrm{PM}_{2.5}$ in the year of death ( $L$ aden et al. 2006). T he particulate air pollution had decreased from the first to the second period (1974-1989 and 1990-1998). W hen compared with the D ockery et al. (1993) study, a decrease in mortality of $27 \%$ was found for each $10 \mu \mathrm{g} / \mathrm{m}^{3}$ reduction in the $\mathrm{PM}_{2.5}$ level between the two periods.

T he most recent cohort study ( $M$ iller et al. 2007) of 66,000 women from 36 U.S. metropolitan areas showed a higher increased risk for cardiovascular 
mortality than described in the cohort studies by L aden et al. (2006 - study of intercity comparisons) and Jerret et al. (2005 - study of intra-city comparisons). In the M iller et al. (2007) study, each increase of $10 \mu \mathrm{g} / \mathrm{m}^{3}$ $\mathrm{PM}_{2.5}$ was associated with a $24 \%$ increase in risk of cardiovascular event and a $76 \%$ increase of death from cardiovascular disease. A considerable higher increased risk of cardiovascular mortality ( $128 \%$ increase per $10 \mu \mathrm{g} / \mathrm{m}^{3} \mathrm{PM}_{2.5}$ ) was observed within cities compared to intercity comparisons ( $58 \%$ increase per $10 \mu \mathrm{g} / \mathrm{m}^{3} \mathrm{PM}_{2.5}$ ).

T he emission of particles from residential wood burning and their impact on human health has received much attention lately.

Several early studies ( $T$ able 5 ) have focused on the presence of a wood stove in the home as a risk factor. While these studies strongly suggest that there are adverse health impacts in form of more respiratory symptoms and diseases associated with wood smoke exposure, their crude exposure assessments preclude more specific conclusions.

In addition, a number of studies ( $\mathrm{T}$ able 7 ) have reported associations of adverse health impacts in the airways with use of biomass fuels. All these studies are observational and very few have measured exposure directly, while a substantial proportion have not dealt with confounding. As a result, risk estimates are poorly quantified and may be biased.

A number of studies ( $T$ able 6 ) have evaluated adverse health effects from ambient air pollution in relation to residential wood combustion in communities where wood smoke was a major, although not the only, source of ambient air particulate. $T$ he studies indicate a consistent relationship between $\mathrm{PM}_{1}, \mathrm{PM}_{2.5}$ and/or $\mathrm{PM}_{10}$ and increased respiratory and asthmatic symptoms, and decreased lung function. T he studies have mainly focused on children, but the few studies focusing on adults as well have shown similar results. T here are also indications from several of the studies that asthmatics are a particularly sensitive group. T he studies giving an indication of the doseresponse relationship are summarised in T able 8 (section 7.2.2.1).

Boman et al. (2003) have reviewed nine selected studies (marked with an asterix in T able 6) concerning adverse health effects from ambient air pollution in relation to residential wood combustion and attempted to extract quantifications for the associations. Only a few studies were found in which residential wood combustion was identified as a (or the) major source of ambient air pollution. In all the studies using $\mathrm{PM}_{10}, \mathrm{PM}_{2.5}$, and $\mathrm{PM}_{1}$ as an indicator of ambient air pollution, significant positive associations between variations in air pollution level(s) and adverse health outcome(s) were found. The relative risks ( $R R$ ) between an increase in ambient $P M_{10}$ with $10 \mu \mathrm{g} / \mathrm{m}^{3}$ and different health outcomes varied between 1.01 and 1.12. An RR for increased asthma hospital admissions of 1.15 and 1.04 has been reported for an increase in ambient $P M_{2.5}$ with 11 and $12 \mu \mathrm{g} / \mathrm{m}^{3}$, respectively. An RR for increased asthma symptoms in children of 1.17 has been reported for an increase in ambient $P M_{1}$ with $10 \mu \mathrm{g} / \mathrm{m}^{3}$.

O verall, these studies showed that an increased risk of experiencing adverse health effects in the respiratory tract from exposure to particles in wood smoke (RR 1.04-1.17) is associated with an increase in ambient PM (PM ${ }_{1}$, $P M_{2.5}$ and $P M_{10}$ ) of about $10 \mu \mathrm{g} / \mathrm{m}^{3}$. N one of the available studies have indicated a threshold concentration for effects. H owever, it should be noted that due to differences in the statistical analyses and presentation of the results in the various studies, it is difficult to compare the results from different studies. 
Boman et al. (2003) also compared the results from the five wood smoke studies in which residential wood combustion was mentioned as an important air pollution source with estimations for the association between PM and health effects in the general environment (Figure 3). All the included studies showed significant positive associations for respiratory symptoms evaluated. In comparison with the estimations concerning ambient PM and health effects in the general environment, the R R were even stronger in the studies in which residential wood combustion was considered a major PM source. Based on this comparison, the authors concluded that there seems to be no reason to assume that the health effects associated with PM in areas polluted with wood smoke are weaker than elsewhere.

A very recently published review ( $\mathrm{N}$ aeher et al. 2007), which is based on an extended list of references, confirms the overall picture presented by Bomann et al. (2003) as well as the present report.

O verall, the available studies indicate that exposure to wood smoke PM is associated with the same kind of health effects known from exposure to PM in general and that the health effects associated with PM in areas polluted with wood smoke are not weaker than elsewhere. H owever, the uncertainties about the actual contribution from wood smoke to ambient concentrations of PM preclude, for the time being, precise characterisations of specific doseresponse relationships for wood smoke PM and whether differences exist compared to the known dose-response relationships from PM in general. T herefore, a more precise evaluation of the impact on human health of air pollution related to residential wood combustion is not possible for the time being.

\subsection{Epidemiological studies, carcinogenic ef fects}

\subsubsection{Particles in the general environment}

D uring the last decade, several cohort studies have been published. T hree studies were performed on cohorts in the $U$ nited States.

T he $\mathrm{H}$ arvard Six Cities study was based on 8111 adults in six U .S. cities followed from 1976 to 1989 (D ockery et al. 1993). Exposure was estimated by assessment of long-term average levels of pollution from background airmonitoring stations. T here was a 37\% (95\% Cl 0.81-2.31) higher lung cancer risk in the most polluted city compared with the least polluted city after adjustment for age, sex, smoking, education and body-mass index.

A study by Beeson et al. (1998) was based on 6338 California Seventh D ay A dventists (non-smoking) followed from 1977 to 1992. Exposure to air pollution was estimated by monthly ambient concentrations of $\mathrm{NO}_{2}, \mathrm{SO}_{2}$ and $\mathrm{PM}_{10}$ using fixed-site monitoring stations, which were interpolated to zip codes of individual home and working addresses. The study reported rate ratios for lung cancer of 5.21 (95\% Cl 1.94-13.99) for $\mathrm{PM}_{10}$ corresponding to an inter-quartile range of $24 \mu \mathrm{g} / \mathrm{m}^{3}$, and of 1.45 (95\% Cl $\left.0.67-3.14\right)$ for $\mathrm{N} \mathrm{O}_{2}$ corresponding to an inter-quartile range of $1.98 \mathrm{ppb}$.

T he largest U S investigation analysed cause-specific mortality among approximately 550000 adults followed from 1982 to 1998 (Pope et al. 1995, 2002). Participants were assigned to metropolitan areas of residence, for which mean $\mathrm{PM}_{2.5}$ concentrations were compiled from urban background 
monitoring stations in 1979-83 and 1999-2000. In this study an increase in yearly mean concentration of $10 \mu \mathrm{g} / \mathrm{m}^{3}$ of $\mathrm{PM}_{2.5}$ was associated with increased lung cancer mortality ( $R \mathrm{R}=1.14 ; 95 \% \mathrm{Cl} 1.04-1.23)$ (Pope et al. 2002).

T hese three U .S. cohort studies suggest an excess risk of lung cancer with long-term exposure to air pollution. H owever, it is unknown whether these results can be transferred to European settings as the European populations may experience different exposures and living habits (smoking, diet etc.), which could modify the results (Vineis et al. 2004).

A cohort study from the $\mathrm{N}$ etherlands found an insignificant $25 \%$ higher lung cancer mortality associated with a $30 \mu \mathrm{g} / \mathrm{m}^{3}$ difference in yearly mean concentration of $\mathrm{NO}_{2}$ level among 5000 subjects between 1984 and 1994, for which the exposure was estimated for the home address (H oek et al. 2002).

$\mathrm{N}$ afstad et al. (2004) investigated the lung cancer incidence among 16209 men living in 0 slo between 1974 to 1998, and found an adjusted risk ratio for lung cancer of $1.08(95 \% \mathrm{Cl} 1.02-1.15)$ for a $10 \mu \mathrm{g} / \mathrm{m}^{3}$ increase in yearly mean concentration of $\mathrm{N} \mathrm{O}_{x}$, but no associations with $\mathrm{SO}_{2}$.

$\mathrm{H}$ arrison et al. (2004) investigated whether exposure to known chemical carcinogens, e.g. PAHs, can explain the observed association between $\mathrm{PM}_{2.5}$ and lung cancer mortality by calculating lung cancer rates. T hey concluded that it appears plausible that known chemical carcinogens are responsible for the lung cancers attributed to $\mathrm{PM}_{2.5}$ exposure. However, they also stated that the possibility should not be ruled out that PM is capable of causing lung cancer independent of the presence of known carcinogens.

\subsubsection{Particles from wood burning}

T here is little direct information regarding the human cancer risks associated with biomass air pollution. The findings of relatively low mutagenicity for wood smoke, have, to some extent, been validated in a study of indoor environmental exposure risks and lung cancer in China. C ross-sectional comparisons of population subgroups in X uan W ei, China, an area noted for high mortality from respiratory disease and lung cancer, suggested that the high lung cancer rates could not be attributed to smoking or occupational exposure ( $M$ umford et al. 1990a). Since residents of X uan W ei, especially women, are exposed to high concentrations of coal and wood combustion products indoors, a study was undertaken to evaluate the lung cancer risks of these exposures. On average women and men in X uan W ei spend 7 and 4 hours per day, respectively, near a household fire. A 1983 survey indicated that the lung cancer rate in $X$ uan $W$ ei was strongly associated with the proportion of homes using smoky coal in 1958. No relationship was observed between lung cancer and the percentage of homes using wood.

A follow-up study compared exposures in two otherwise similar $\mathrm{X}$ uan W ei communes, one with high lung cancer mortality $(152 / 100,000)$ where smoky coal was the major fuel, and another with low lung cancer mortality $(2 / 100,000)$ where wood (67\%) and smokeless coal (33\%) were used. L ung cancer mortality was strongly associated with indoor burning of smoky coal and not with wood burning. T his association was especially strong in women who had low smoking and were more highly exposed to cooking fuel emissions than men (Chapman et al. 1988). Indoor $\mathrm{PM}_{10}$ concentrations 
measured during cooking were extremely high $\left(24,22\right.$ and $1.8 \mathrm{mg} / \mathrm{m}^{3}$ for smoky coal, wood and smokeless coal, respectively). In contrast to other studies of wood smoke particle size distribution, measurements in X uan W ei indicated that only $6 \%$ of the particles emitted during wood combustion were smaller than $1 \mu \mathrm{m}$ in size, whereas $51 \%$ of the smoky coal particles were submicron. T his study suggests that there was little association between open-fire wood smoke exposure and lung cancer, despite very high exposures with long duration (women generally start cooking at age 12). O ne possible explanation is the relatively low biological activity of wood smoke particulate combined with less efficient deposition of the larger particles.

In a recent study, M ustapha et al. (2004) evaluated the D N A damage in 179 Indian women cooking with biofuels, including wood. T hey found a significant increase in both micronucleus ( $\mathrm{M} \mathrm{N}$ ) and chromosomal aberrations (CA) in peripheral lymphocytes from users of biomass fuel compared to lymphocytes from users of liquefied petroleum gas (LPG). T he relative M N and $C A$ frequencies for the users of the various fuels decreased in the order cow dung $>$ cow dung / wood $\geq$ wood $>$ kerosene $\geq$ L PG. F urther, the results indicated an effect of subject age, and the duration of exposure on the $\mathrm{M} \mathrm{N}$ and CA frequencies in biomass fuel users.

The frequency of sister chromatid exchange (SCE) after acute overexposure to combustion products originating from coal or wood stoves was investigated in 20 patients with acute carbon monoxide intoxication (Ozturk et al. 2002). All cases were domestic accidents due to dysfunctioning coal or wood stoves. T he mean SCE frequency per metaphase was significantly higher in the study group compared to the control group: $8.11( \pm 2.39)$ vs. $6.33( \pm 1.60)$. T here was no positive correlation between the blood carboxyhaemoglobin concentration and SCE frequency. T he results suggest that acute exposure to combustion products of wood or coal is genotoxic.

L ong-term exposure to wood smoke from cooking was found to contribute to the development of lung cancer in a case-control study of M exican nonsmoking women (Hernandez-G arduno et al. 2004). Exposure information was obtained from 113 lung cancer cases and 273 controls. C ontrols were patients with miscellaneous pulmonary conditions (e.g. pulmonary tuberculosis, interstitial lung disease). Exposure to wood smoke for more than 50 years, but not for shorter periods, was associated with lung cancer after adjusting for age, education, socio-economic status and environmental tobacco smoke exposure, odds ratio 1.9 (95\% confidence interval 1.1-3.5).

A case-control study has shown that the use of wood stoves for cooking or heating may be linked to as many as $30 \%$ of all cancers in mouth, pharynx and larynx in Southern Brazil (Pintos et al. 1998). Information on known and potential risk factors was obtained from 784 cases and 1568 non-cancer controls. A fter adjustment for all empirical confounders (e.g. smoking, alcohol consumption), the odds ratio for all upper aero-digestive tract cancers was 2.68 (95\% confidence interval: 2.2-3.3). Increased risks associated with use of wood stoves were also seen in site-specific analyses for mouth, pharynx and larynx. An important limitation of this study was the lack of exposure assessment; there was no information on lifetime or average daily exposure, house ventilation, or the presence of a kitchen separated from the rest of the house. 
Recently, Ramanakumar et al. (2006) performed a case-control study among 1205 persons diagnosed with lung cancer during the period 1996-2001 in $M$ ontreal and 1541 controls using questionnaire information about heating and cooking facilities. A mong women using traditional heating facilities (stove or fireplace) and traditional cooking facilities (gas or wood stove) they found an increased odds ratio of $2.5(95 \% \mathrm{Cl} 1.5-3.6)$ after adjusting for smoking and a number of other covariates. The authors speculated that the lack of a significant correlation for men may be due to less exposure from the heating and cooking sources because of less time spent in the home and less time spent in the kitchen.

\subsubsection{Summary, carcinogenic effects}

D uring the last decade, several cohort studies on cancer risk due to exposure to particles in the general environment have been published. T hree U.S. cohort studies (D ockery et al. 1993, Beeson et al. 1998, Pope et al. 2002) suggest an excess risk of lung cancer with long-term exposure to air pollution. O ne study (Beeson et al. 1998) reported a rate ratio for lung cancer of 5.21 for $\mathrm{PM}_{10}$ corresponding to an inter-quartile range of $24 \mu \mathrm{g} / \mathrm{m}^{3}$. In another study (Pope et al. 2002), the largest one, an increase in the yearly mean concentration of $10 \mu \mathrm{g} / \mathrm{m}^{3}$ of $\mathrm{PM}_{2.5}$ was associated with increased lung cancer mortality ( $R R=1.14)$. A cohort study from the $\mathrm{N}$ etherlands ( $\mathrm{H}$ oek et al. 2002) found a $25 \%$ higher lung cancer mortality associated with a $30 \mu \mathrm{g} / \mathrm{m}^{3}$ difference in yearly mean concentration of $\mathrm{N}_{2}$, and a $\mathrm{N}$ orwegian study ( $\mathrm{N}$ afstad et al. 2004) found an adjusted risk ratio for lung cancer of 1.08 for a $10 \mu \mathrm{g} / \mathrm{m}^{3}$ increase in yearly mean concentration of $\mathrm{N} \mathrm{O}_{x^{*}}$ A recent study ( $\mathrm{H}$ arrison et al. 2004) found it plausible that known chemical carcinogens, e.g. PAHs, associated with the PM are responsible for the lung cancer risk attributable to $\mathrm{PM}_{2.5}$ exposure; however, it was also stated that it should not be excluded that PM in itself is capable of causing lung cancer independent of the presence of known carcinogens.

T here is limited information regarding the human cancer risks associated with biomass air pollution. T he $C$ hinese studies ( $M$ umford et al. 1990a, C hapman et al. 1988) on an association between wood smoke exposure and lung cancer risk do not indicate an increased risk even after long-term exposure to very high levels of biomass smoke $\left(\mathrm{PM}_{10} 22 \mathrm{mg} / \mathrm{m}^{3}\right)$ from open-fire domestic cooking. T wo more recent case-control studies from $\mathrm{M}$ exico ( $\mathrm{H}$ ernandez$G$ arduno et al. 2004) and Southern Brazil (Pintos et al. 1998) are suggestive of a small increased risk of lung cancer due to long-term exposure to wood smoke from cooking; however, these studies are limited by the lack of exposure assessments. T he most recent case-control study (Ramanakumar et al. 2006) found an increased risk for lung cancer among $C$ anadian women in homes with wood stove or fireplace heating and with gas or wood stove cooking facilities.

O ne study ( $M$ ustapha et al. 2004) has reported a significant increase in the occurrence of both micronuclei and chromosomal aberrations in peripheral lymphocytes from Indian women cooking with bio-fuels, including wood. O verall, there is limited information regarding the human cancer risk associated with biomass air pollution, including wood smoke. The available studies do not provide a sufficient basis in order to evaluate whether there is an association between wood smoke exposure and increased risk of lung cancer. 
C ohort studies on cancer risk associated with particles in the general environment have suggested an excess risk of lung cancer associated with long-term exposure to PM . K nown chemical carcinogens, e.g. PAHs, associated with the PM might be responsible for the excess risk of lung cancer; however, it can not be excluded that PM in itself is capable of causing lung cancer.

It should be noted that the International Agency for Research on $C$ ancer (IARC 2008) has evaluated that indoor emissions from household combustion of biomass fuel (primarily wood) are probably carcinogenic to humans ( $G$ roup $2 A$ ). In reaching this evaluation, the IA $R C$ W orking $G$ roup considered mechanistic and other relevant data including the presence of PAH s and other carcinogenic compounds in wood smoke, evidence of mutagenicity of wood smoke and multiple studies that show cytogenetic damage in humans who are exposed to wood smoke. 


\section{Experimental studies}

\subsection{Human studies}

Only one study has been found with experimental exposure of human volunteers to wood smoke PM.

The aim of this study was to examine whether short-term exposure to wood smoke affects markers of inflammation, blood haemostasis, and lipid peroxidation in healthy humans. Thirteen healthy persons ( 6 men and 7 women aged 20-56 years - mean 34 years) were exposed to wood smoke or clean air in an exposure chamber during two 4-hour sessions, 1 week apart $\left(\mathrm{PM}_{2.5}\right.$ levels of $240-280 \mu \mathrm{g} / \mathrm{m}^{3}$; number PM concentration levels of 95,000$180,000 / \mathrm{cm}^{3}$ ) (Barregard et al. 2006).

In addition to increased PM levels, the wood smoke also resulted in increased levels of VOCs (formaldehyde, acetaldehyde, 1,3-butadiene and aromatic hydrocarbons e.g. benzene) (Sällsten et al. 2006).

Subjective symptoms were weak, with mild eye irritation after the wood smoke exposure. Blood and urine samples were analysed before and after exposure for markers of inflammation, coagulation and lipid peroxidation. T here was a tendency toward an increase (about 10\%) of high-sensitivity serum $\mathrm{C}$-reactive protein (CRP), a marker of inflammation. Significant increases were found in serum amyloid $A$ (an acute-phase protein that parallels CR P and considered to be an inflammatory cardiovascular risk factor) and in plasma factor VIII (considered as a marker both of inflammation and of haemostasis) and in the ratio factor VIII/von W illebrand factor indicating a slight effect on the balance of the coagulation factors. $M$ oreover there was an increased urinary excretion of free 8-isoprostaglandin ${ }_{2 \alpha}$ indicating a temporary increase in free radical-mediated lipid peroxidation.

The authors concluded that wood smoke particles, at levels that can be found in smoky indoor environments, seem to affect inflammation, coagulation, and possibly lipid peroxidation, factors that may be involved in the mechanisms whereby particulate air pollution affects cardiovascular morbidity and mortality.

\subsection{Studies in experimental animals}

In general, the toxicological studies of air pollutants are short-term experimental studies. T hese studies have often analysed the early events rather than waiting for final disease, such as reduced respiratory system development, and they often focus on cells and biochemical systems rather than whole animals.

T wo approaches have generally been used to studying the adverse health effects of particulate matter in animals: 1) placing suspensions of the test substances in the nose or the trachea, or 2) inhalation of aerosols. Rodents have primarily been used in the studies to test the mechanisms of pollutantinduced lung and airway injury and as models for infection processes and the 
functioning of the immune system. Rats in particular appear to be susceptible to chronic inflammation, fibrous tissue development, and cancer from insoluble, non-cytotoxic particles, via a process believed to involve the overwhelming of normal particle removal mechanisms ( particle overload).

D osage rates and tissue concentrations are key factors in determining toxicity. $M$ any toxicological effects are related to inhalation exposure integrated over time, especially in those situations where exposure is of longer term. H owever, certain effects may be more related to peak exposures, such as local irritation in the upper and lower airways.

Comparison between the effects in rodents and those in human beings can be rather difficult. This is due to anatomical and physiological differences, which can result in considerably lower concentrations in sensitive regions of the respiratory tract and the lungs of animals, compared to similar regions in humans. Furthermore, experimental animals used in toxicological studies are genetically very similar within specific strains, whereas human populations are heterogeneous. T hus, extrapolation of results from experimental animals to humans must also take strain and species differences into account.

T he effects of air pollutants may also be studied in isolated lungs from animals, cultures of various anatomical structures of the respiratory tract from animals, cultures of various cell types lining the respiratory system, and subcellular fractions of tissues and cells. Such in vitro studies are useful for characterising the mode of action / mechanisms for air pollutants and for studying biochemical aspects of qualitative and quantitative species differences in toxicity. Given the complex physiological and pathological reactions taking place in the intact organism when animals are exposed to air pollutants via inhalation, in vitro studies cannot in isolation be used for hazard characterisation purposes.

\subsubsection{Particles in the general environment, an overview}

\subsubsection{N on-carcinogenic effects}

A brief overview of the non-carcinogenic effects of particles observed in studies of experimental animals is given in the following based on the AIR N ET toxicology report (D ybing \& T otlandsdal 2004).

T oxicological studies in experimental animals suggest that PM can influence the functioning of the lung, the blood vessels and the heart.

M uch of the toxicological evidence indicating the potential of PM to induce toxicity arises from direct high dose administration of PM into airways and lungs. H owever, the few inhalation studies available also indicate that PM may induce toxicity and studies have shown dose-dependent PM -induced adverse effects, albeit at concentrations well above ambient exposure. Some studies have concluded that focusing not on mass but on the (reactive) surface area of PM is a better method of linking adverse effects with PM .

The toxicity studies of PM have often been performed on specific fractions of $P M$, acidic aerosols, organic fractions, mixtures of particles and gaseous compounds, transition metals and particle charge while the ambient PM is a complex mixture. $\mathrm{N}$ ot only particles of a certain chemical composition are responsible for the adverse effects of PM but the effects observed might 
depend very much on the chemical composition of PM . T hus, adverse health effects are unlikely to be related to a single PM fraction, but more likely to a complex, eventually synergistic interaction of multiple PM components with the respiratory tract and subsequent target organs.

For example, inflammatory responses in the lung have been noted with chemically diverse PM mixtures. T he effects have also been observed with particles of a presumed low intrinsic toxicity such as carbon black or metal oxides indicating that other conditions, e.g. surface area, may also play an important role in the induction and development of adverse health effects.

T here are, however, preliminary indications that primary, carbonaceous PM components may be more important for adverse health effects than secondary components like sulphates and nitrates.

Experimental studies have supported the potential for combined gas-particle interactions such as fine carbon or diesel, acidic, or dispersed ambient particles combined with (in)organic gases or vapours (e.g. ozone, nitrogen dioxide, nitric acid, aldehydes). As an example, prolonged exposure (4 weeks) of rats to a mixture of carbon black, ammonium bisulphate and ozone showed more inflammatory effects than with the components individually.

D iesel exhaust contains various respiratory irritants in the gas phase and in the particulate matter. Both can induce inflammatory responses in the airways and alveolar regions of the lung. Airway inflammation involves damage to epithelial cells, including lipid peroxidation of cell membranes by oxidizing gaseous pollutants such as nitrogen dioxide. Indirect effects of particles, resulting from phagocytosis, can include the formation and release of various mediators, including oxidants, such as superoxide anions and hydroxyl radicals, and cytokines. T hese mediators may play a role in focal loss or shortening of cilia, type II cell hypertrophy, and hyperplasia. T he latter changes can lead to the hyperplastic lesions seen in animals exposed to diesel exhaust. Phagocytosis and subsequent clearance of particles by alveolar macrophages can be compromised by high particle burdens, which may also increase the access of particles to the interstitium, leading to focal fibrosis. (Henderson et al. 1988).

$\mathrm{N}$ ot only particles of a certain size are responsible for the adverse effects of PM . Both coarse and fine particles are capable of inducing toxicity. Recently, ultrafine particles ( $<0.1 \mu \mathrm{m}$ in diameter) have emerged as a possible cause of PM -associated adverse health effects. T oxicological studies indicate that ultrafine particles could produce serious health effects. O ngoing studies suggest that traffic-generated ultrafine particles, on an equal mass basis, are more potent compared to fine or coarse particles. H owever, studies using factory-produced ultrafine carbon black did not confirm this observation indicating an important role for the chemical composition on the surface of PM . W hether the ultrafine PM fraction, tested at environmentally relevant levels, is also toxic, remains more uncertain.

In most studies, normal healthy animals have been used, but during the last years, animal models that resemble human diseases have gained more attention as tools for understanding how air pollution may affect the diseased and susceptible individual. For example, experiments have been carried out using models of asthma, C OPD (C hronic O bstructive Pulmonary D isease), allergy, lung inflammation, increased blood pressure in the lung arteries, and 
general high blood pressure. There is now some support for the assumption that the presence of disease increases the susceptibility to PM pollutants. Some studies have also compared responses in ageing rodents with younger ones.

\subsubsection{Carcinogenic effects}

A review of the literature on the carcinogenic effects of particles and PAHs in animals is included in the WHO Environmental Health Criteria 171 (EHC 1996). T he major findings from this review are summarised in the following.

C arbon black is the powdered form of elemental carbon manufactured by vapour-phase pyrolysis of hydrocarbons. In this respect, it is partly similar to black soot such as that produced in wood burning. H owever, the content of carbon in soot is lower and soot usually contains much more PAH and other materials that can be extracted with organic solvents. (IARC 1996).

The importance of pulmonary particle burden on lung tumour induction has been demonstrated clearly in long-term studies by inhalation in rats. $R$ ats have similarly increased lung tumour incidences when exposed to diesel exhaust or carbon black particles by inhalation for 24 months. Similarly, carbon black particles practically devoid of PAH s induce pulmonary tumours after intratracheal instillation. The very large surface area of carbon black and of diesel exhaust particles after de-sorption of adsorbed organic compounds in vivo may be involved mechanistically in a carcinogenic effect. The tumour response to different types of carbon black particles instilled intra-tracheally has been shown to correlate well with their respective surface areas ( $\mathrm{H}$ einrich 1994).

T he correlation between particle surface area and lung tumour incidence was examined by evaluating published studies of inhalation of diesel and other particles. T umour induction in rats was best correlated with the surface area of the particles retained in the lung rather than with the particle mass, particle volume, or number of particles, regardless of the PAH content. It was suggested that particle surface area and surface properties play a decisive role and that absorbed PAHs are not responsible for the tumour response in rats exposed to diesel exhaust. In the human situation, however, it could not be excluded that organic compounds and gas-phase components are also involved, since the human particulate lung burden is much lower than those achieved in rats after long-term inhalation.

Inhalation of diesel engine exhaust can result not only in pulmonary tumours but also in inflammation and fibrosis and in a delay in alveolar pulmonary clearance. T he mechanism by which tumours develop due to particle overload and its associated pathological and anatomical changes may be restricted to rats and may not occur under environmental conditions in humans, since the lung burdens of humans do not reach the levels that induce lung tumours in rats. T his is of importance for quantitative risk assessment. O nly occupational exposure to diesel exhaust may result in lung burdens near or at overload conditions, particularly if the lung is already compromised by exposure to other dusts. R etarded particle clearance in smokers has been reported; in these people, additional exposure to diesel exhaust may induce overload and associated toxic effects (Bohning et al. 1982). 
$\mathrm{N}$ ot only diesel soot (particle size $<50 \mathrm{~nm}$ ) but also carbon black nearly completely devoid of organic compounds (Printex 90 , particle size $10 \mathrm{~nm}$ ) and ultrafine titanium dioxide ( $\mathrm{T} \mathrm{iO}_{2}$ ) particles (particle size $20 \mathrm{~nm}$ ) caused lung tumours in female $W$ istar rats exposed by inhalation for 18 hours/day on five days per week for 24 months to a concentration at about $7.5 \mathrm{mg} / \mathrm{m}^{3}$. T he tumour rate increased with increasing particle concentrations, independently of the type of particles inhaled. T he authors concluded that the carcinogenic component of diesel exhaust is in the inner part of the diesel soot particle, the carbon core, and is not the relatively small amount of carcinogenic PAH s (H einrich 1994). T hese results were confirmed in another two-year study, in which male and female rats were exposed by inhalation to various concentrations of carbon black and diesel exhaust. L ung tumours were observed with both particle types ( $\mathrm{N}$ ikula et al. 1995). D iesel soot does not appear to have a specific carcinogenic effect in rats; rather, there is a nonspecific effect of particles.

Exposure of rats by inhalation to $2.6 \mathrm{mg} / \mathrm{m}^{3}$ of an aerosol of tar-pitch condensate with no carbon core but containing $50 \mu \mathrm{g} / \mathrm{m}^{3}$ benzo[a]pyrene and other PAH s for 10 months caused lung tumours at a rate of $39 \%$. The same amount of tar-pitch vapour condensed onto the surface of carbon black particles at 2 and $6 \mathrm{mg} / \mathrm{m}^{3}$ resulted in tumour rates that were roughly two times higher ( 89 and $72 \%$, respectively). Since exposure to $6 \mathrm{mg} / \mathrm{m}^{3}$ carbon black almost devoid of extractable organic material caused a lung tumour rate of $18 \%$, the tumour rate of $72 \%$ seen after combined exposure to tar-pitch vapour and carbon black particles indicates a syn-carcinogenic effect of PAH s and carbon black. A possible mechanism involves an effect of deposition of PAHs (H einrich et al. 1994). As the level of benzo[a]pyrene in the coal-tar pitch was about three orders of magnitude greater than those in diesel soot, PAH s may play a negligible role in the carcinogenicity of diesel soot in rats. T he PAH profile in diesel soot is, however, quite different from that in coaltar pitch, as diesel soot contains highly mutagenic, carcinogenic nitro-PAHs and other poorly characterized mutagens that are not present in coal-tar pitch or on some of the carbon black particles used in experimental studies ( $\mathrm{N}$ ikula et al. 1995, H einrich et al. 1994).

K naapen et al. (2004) reviewed the literature on particle induced lung cancer in order to elucidate the underlying mechanisms with focus on the role of reactive oxygen and nitrogen species. Both the particles themselves as well as particle-elicited events, such as activation of pathways of inflammation and proliferation, have been suggested to play a role in particle-induced genotoxicity, mutagenesis and carcinogenicity. T he central hypothesis based on rat studies is that inflammation drives genotoxic events in airway epithelium as well as cell proliferation and tissue remodelling, which are processes that are all required for mutations and progression towards neoplastic lesions. Both particles and inflammatory cells can cause genetic damage as well as proliferative effects to target cells ( $T$ ype II epithelial cells and Clara cells) through the production and release of oxidants.

\subsubsection{Particles from wood smoke}

\subsubsection{N on-carcinogenic effects}

Zelikoff et al. (2002) recently reviewed the health effects associated with exposure to wood smoke, in particular with focus on the immune system as a target. T he information in this review is summarised in the following. 
A though health effects associated with exposure to whole wood smoke emissions are not as well studied as its individual components, a number of adverse health effects have been demonstrated. F or example, exposure of laboratory animals to wood smoke effluents decreased ventilatory frequency and ventilatory response to $\mathrm{CO}_{2}$ (W ong et al. 1984), increased micro-vascular permeability and produced pulmonary oedema ( $\mathrm{N}$ ieman et al. 1989), caused necrotising tracheobronchial epithelial cell injury (T horning et al. 1982), possibly increased the lung cancer incidence in mice ( $L$ iang et al. 1988), increased levels of angiotensin-1-converting enzyme in the lungs (Brizio$M$ olteni et al. 1984), and compromised pulmonary macrophage-mediated immune mechanisms important in anti-microbial defence (Zelikoff et al. 1995a,b), most likely via alterations in the integrity of the macrophage surface membrane or cytoskeletal components (Fick et al. 1984, L oke et al. 1984).

O nly a limited number of studies have investigated the effects of whole wood smoke emissions on pulmonary immunity. It appears that host defence and/or immune cell function is depressed in a manner similar to that produced by many of the individual wood smoke constituents (Zelikoff et al. 2002). F or example, a single inhalation exposure of rabbits to smoke from the pyrolysis of D ouglas fir wood produced an increase in the total number of recovered pulmonary macrophages and a transitory decrease in macrophage adherence to glass ( $F$ ick et al. 1984). M oreover, this same exposure regime decreased macrophage uptake of the gram-negative bacterial pathogen Pseudomonas aeruginosa in the absence of an inflammatory response or changes in macrophage viability.

In another study, a single inhalation exposure of D ouglas fir-generated wood smoke altered the macrophage morphology and membrane ultra-structure (L oke et al. 1984).

Inhaled wood smoke has also been reported to alter the chemotactic migration of broncho-pulmonary lavage human macrophages (D emarest et al. 1979).

In studies by Zelikoff et al. (1995a,b), 3-month-old Sprague-D awley rats were exposed repeatedly ( 1 hour/day, 4 days) to a single concentration of wood smoke $\left(750 \mu \mathrm{g} / \mathrm{m}^{3} \mathrm{PM}_{2.5}\right.$ ) generated from red oak burned in a combustion furnace. At 3, 24, 72 and 120 hours following the final wood smoke exposure, rats were intra-tracheally instilled with the pneumonia-producing bacteria Staphylococccus aureus to assess effects upon pulmonary clearance. Inhalation of wood smoke progressively reduced the in vivo clearance/killing of $S$. aureus. Effects of inhaled wood smoke on intrapulmonary clearance appeared as early as 3 hours following the final exposure and persisted for up to 5 days; killing/clearance was reduced to $60 \%$ of control values after 3 hours and then progressively declined to $2 \%$ after 5 days. T he authors stated that the results demonstrated that short-term repeated inhalation of wood smoke generated from the burning of a common hardwood used for home heating compromised pulmonary host resistance against an infectious, pneumoniaproducing lung pathogen well after exposures ceased.

In addition to the studies reviewed by Zelikoff et al. (2002), a few recent studies have investigated the effects of wood smoke.

Reed et al. (2006) have summarised health effects in rats and mice of subchronic exposure to environmental levels of hardwood smoke (HWS) generated from an uncertified wood stove burning wood of mixed oak species. A nimals were exposed by whole-body inhalation ( 6 hours/day, 7 days/week) for either 1 week or 6 months to clean air (control) or dilutions of whole 
emissions based on particulate ( 30 (low-level exposure, L), 100 (mid-level exposure low, M L ), 300 (mid-level exposure high, M H) , or 1000 (high-level exposure, $\mathrm{H}$ ) $\mu \mathrm{g} / \mathrm{m}^{3}$ total $P M$ ).

T he fractional abundance of the primary PM constituents showed that PM was composed of approximately 93\% organic carbon mass at all exposure levels. In addition, there was approximately $5 \%$ elemental carbon and 2-3\% metals and other elements. PM in the HW S exposure atmospheres had a mass median aerodynamic diameter of approximately $0.3 \mu \mathrm{m}$, with a small increase in particle size (0.25-0.35 $\mu \mathrm{m}$ median diameter) at the higher exposure levels. T he dominant gases were carbon monoxide (maximum approximately 15 $\mathrm{mg} / \mathrm{m}^{3}$, high-level exposure) and volatile organics (maximum approximately $3.5 \mathrm{mg} / \mathrm{m}^{3}$, high-level exposure).

F 344 rats (12 of each sex per group) were used for assessment of body weight, organ weight, histopathology, clinical chemistry and haematology parameters. Spontaneously hypertensive rats (SHR, 6 of each sex per group) were used for EK G, heart rate analyses and vessel histopathology. C 57B L /6 mice ( 16 males per group) were used for assessment of bacterial clearance and inflammatory lung histopathology. Y oung strain A/J mice (10/20 of each sex per group) were used for assessment of body weight, organ weight, micronucleus formation, histopathology and carcinogenesis (20 of each sex per group).

$\mathrm{N}$ o exposure-related clinical abnormalities, mortality or effects on body weight were observed.

Organ weights: A bsolute liver weight was slightly decreased in $\mathrm{H}$ rats of both sexes at 1 week (maximum 8-9\%) and relative liver weights in $\mathrm{H}$ female rats at 6 months (maximum 3\%). Excised, fixed lung volume was increased (maximum $12 \%$ ) in $\mathrm{H}$ female rats at 6 months. L ung weight was decreased (maximum 16\%) in $\mathrm{H}$ female mice at 6 months. Spleen weight was increased in $\mathrm{H}$ female rats (maximum $9 \%$ ) and $\mathrm{ML} / \mathrm{M} \mathrm{H}$ mice (maximum $53 \%$ ) at 1 week. T hymus weight was decreased (maximum $17 \%$ ) in $\mathrm{H}$ male rats at 1 week.

Clinical chemistry: Blood urea nitrogen (BUN) was decreased in $\mathrm{M} \mathrm{L/M} \mathrm{H/H}$ female rats and in $\mathrm{M} \mathrm{H} / \mathrm{H}$ male rats at 1 week (maximum 35\%) and in $\mathrm{H}$ female rats at 6 months (maximum 18\%). Serum creatinine was decreased in $\mathrm{M} \mathrm{H} / \mathrm{H}$ male rats at 1 week (maximum 13\%) and a negative trend was evident in female rats at 1 week. Alkaline phosphatase was decreased in $\mathrm{M} \mathrm{L/M} \mathrm{H} / \mathrm{H}$ female rats and in $\mathrm{H}$ male rats at 1 week (maximum 23\%) and in $\mathrm{M} \mathrm{H} / \mathrm{H}$ rats of both sexes at 6 months (maximum 38\%). A spartate aminotransferase was decreased in $\mathrm{H}$ male rats at 1 week (maximum 24\%) and a negative trend was evident at 6 months. Other parameters (serum bilirubin, serum cholesterol, glucose, phosphorous and total protein) did not reflect coherent patterns. $\mathrm{H}$ aematology and clotting factors: Platelets were increased in $\mathrm{M} \mathrm{L} / \mathrm{M} \mathrm{H}$ rats of both sexes and in $\mathrm{H}$ female rats at 1 week (maximum 21\%). T otal white blood cell counts were increased in $\mathrm{H}$ females at 1 week (maximum $27 \%$ ) and a positive trend was observed in males at this time point. Eosinophils were decreased in M L/M H male rats at 1 week (maximum 39\%). L ymphocyte counts were increased in L/M L/M H male rats at 6 months (maximum 13\%) and a positive trend was evident in male rats at 1 week.

$\mathrm{H}$ istopathology: $T$ he only exposure-related histopathological findings were in the lung. $M$ inimal increases in alveolar macrophages and sparse brownappearing macrophages were observed in rats. Very little accumulation of particulate matter was observed in the lungs of both rats and mice. Summary inflammatory scores of C 57BL/6 mice instilled with bacteria were largely unaffected by exposure. 
M icronucleus: T here were no statistically significant exposure-related effects on micro-nucleated reticulocyte counts in mice as well as no significant trends.

Carcinogenesis: See section 6.2.2.2.

Bacterial clearance: Bacterial clearance was unaffected by exposure at both the 1-week and 6-month intervals except for a slight downward trend in clearance at the 6-month high-level exposure.

C ardio-vascular endpoints: No significant changes in any of the measured parameters were observed under any exposure condition.

According to the authors, the results reported suggest that these realistic concentrations of H W S present little to small hazard with respect to clinical signs, lung inflammation and cytotoxicity, blood chemistry, haematology, cardiac effects, and bacterial clearance. H owever, the authors also noted that exposure to HWS generated in this study was reported to have mild effects in mouse and rat models of asthma (Barrett et al. 2006, T esfaigzi et al. 2005) and mild effects on pulmonary lavage parameters (Seagrave et al. 2005), see below.

Barrett et al. (2006) used two different models to characterise the effects of inhaled hard wood smoke (HWS) on allergic airway inflammation. In both models, male BALB/C mice were sensitised by injection with ovalbumin (OVA) and alum. In one model, mice were challenged by inhalation with OVA 1 day prior to exposure to HWS $\left(30,100,300\right.$, or $\left.1000 \mu \mathrm{g} \mathrm{PM} / \mathrm{m}^{3}\right)$ for 6 hours/day on 3 consecutive days. In the other model, mice were exposed by inhalation to OVA, rested for 11 days, were exposed to HW S for 3 consecutive days, and then were exposed to OVA immediately after the final HWS exposure. Broncho-alveolar lavage (BAL), and blood collection were performed about 18 hours after the last HWS or OVA exposure. In the first model, H W S exposure after the final allergen challenge led to a significant increase in BAL eosinophils only at the $300 \mu \mathrm{g} \mathrm{PM} / \mathrm{m}^{3}$ level. In the second model, in contrast to the first model, changes in BAL cells did not reach statistical significance. T here were no H W S-induced changes in BAL interleukin (IL )-2, IL -4, IL -13, and interferon (IF N ) $\gamma$ levels in either model following OVA challenge. According to the authors, these results suggest that acute HW $\mathrm{H}$ exposure can minimally exacerbate some indices of allergic airway inflammation when a final OVA challenge precedes HWS exposure, but does not alter $\mathrm{T} h 1 / \mathrm{T}$ h2 cytokine levels.

T esfaigzi et al. (2005) exposed Brown $\mathrm{N}$ orway rats immunized with ovalbumin to either filtered air or wood smoke at $1 \mathrm{mg} \mathrm{PM} / \mathrm{m}^{3}$ for 70 days and challenged them with allergen during the last 4 days of exposure. Baseline values for dynamic lung compliance were lower while functional residual capacity was increased in rats exposed to wood smoke compared to rats exposed to filtered air. Interferon (IFN) $\gamma$ levels were reduced and interleukin (IL )-4 levels increased in the broncho-alveolar lavage fluid and blood plasma, inflammatory lesions in the lungs were $21 \%$ greater, and airway mucous cells/mm basal lamina were non-significantly increased in rats exposed to wood smoke compared to controls. According to the authors, these studies suggest that the pulmonary function was affected in rats by exposure to wood smoke and this decline was associated with only minor increases in inflammation of the lung.

Seagrave et al. (2005) exposed groups of rats ( 12 rats of each sex per group) 6 hours/day, 7 days/week for 6 months to either clean air, diesel exhaust or hardwood smoke at 4 concentration levels between 30 and $1000 \mu \mathrm{g} / \mathrm{m}^{3}$ total 
PM . L ung lavage fluid was assayed for toxicity indicators, cytokines and glutathione. $L$ actate dehydrogenase, total protein, alkaline phosphatase, $\beta$ glucuronidase, macrophage inflammatory protein-2, tumour necrosis factor- $\alpha$, and total glutathione were affected by the exposure to diesel exhaust and/or hardwood smoke; however, no consistent response pattern was found in comparison between diesel exposure and hard wood exposure. Furthermore, some of the responses were found to be gender dependent with a tendency to greater effects in males compared to females. Several indicators were found not to follow a conventional linear dose-response relationship and responses at lower exposure levels were often more pronounced than at the highest exposure level where the responses were suppressed indicating the relevance of testing at relevant environmental exposure levels.

The effects of hardwood smoke (H W S) inhalation (30, 100, 300, and 1000 $\mu \mathrm{g} / \mathrm{m}^{3}$ ) on the systemic immune responses of $A / J$ mice were evaluated after 6 months of daily ( 6 hours/day) whole-body exposures (Burchiel et al. 2005). HWS was generated from a conventional, uncertified wood stove. T he dominant gases were vapour-phase hydrocarbons and carbon monoxide. PM in the wood smoke exposure atmospheres had a mass median aerodynamic diameter of approximately $0.3 \mu \mathrm{m}$, with a small increase in particle size $(0.4$ $\mu \mathrm{m}$ median diameter) at the higher exposure levels. T he PM was composed primarily of organic carbon with approximately 3-10\% Black Carbon and less than $1 \%$ of the transition metal elements ( $\mathrm{K}, \mathrm{Ca}$, and $\mathrm{Fe}$ ). HW S PAH s were enriched in the lower molecular weight compounds (naphthalene and methylated naphthalenes, fluorene, phenanthrene, and anthracene). Spleen cells from the mice were assessed for changes in cell number, cell surface marker expression ( $B, T$, macrophage, and natural killer cells), and responses to $B$ cell (LPS, endotoxin) and T cell ( $C$ on A) mitogens. HWS inhalation caused an increase in $T$ cell proliferation in the $100 \mu \mathrm{g} / \mathrm{m}^{3}$ exposure group and produced a concentration-dependent suppression of $\mathrm{T}$ cell proliferation at concentrations $>300 \mu \mathrm{g} / \mathrm{m}^{3}$. T here were no effects on B cell proliferation, or in spleen cell surface marker expression. The results show that environmentally relevant concentrations of HWS may be immunosuppressive to the immune system of mice exposed during a 6 -month period.

In a study of sub-chronic exposure to low levels of wood smoke, minor but significant changes in the airways of rats were observed ( $T$ esfaigzi et al. 2002). B rown N orway rats were whole-body exposed 3 hours/day, 5 days/week for 4 or 12 weeks to 1 or $10 \mathrm{mg} / \mathrm{m}^{3}$ wood smoke particles from pinus edulis. C ontrol rats were exposed to air. The wood smoke was generated in a wood stove type generally used in the homes of $\mathrm{N}$ ative A merican population in $\mathrm{N}$ ew $\mathrm{M}$ exico, and consisted of fine particles $(<1 \mu \mathrm{m})$ that formed larger chains and aggregates having a size distribution of $63-74 \%$ in the $<1 \mu \mathrm{m}$ fraction and $26-37 \%$ in the $>1 \mu \mathrm{m}$ fraction. T he particle-bound material was primarily composed of carbon and the majority of identified organic compounds consisted of sugar and lignin derivatives. Pulmonary function, specifically carbon monoxide-diffusing capacity and pulmonary resistance, was somewhat affected in the high-exposure group. M ild chronic inflammation and squamous metaplasia were observed in the larynx of the exposed groups. T he severity of alveolar macrophage hyperplasia and pigmentation increased with smoke concentration and length of exposure, and the alveolar septae were slightly thickened.

Exposure of rats in a nose-only chamber to smoke from burning D ouglas fir $(5,10,15$, or 20 minutes of continuous inhalation) and 24-hour recovery time 
revealed acute inflammation of the airways with varying degrees of injury from loss of cilia, degeneration of epithelium and squamous metaplasia to sub-mucosal oedema (Bhattacharyya et al. 2004). T hese histological changes were reflected in variable expression of the secretory M uc5AC mucin gene and low expression of the membrane-associated M uc4 mucin gene.

Park et al. (2004) evaluated the antioxidant status and the extent of pulmonary injury in sheep after graded exposure to wood smoke. A dult male sheep were received $0,5,10$ or 16 units of cooled western pine bark smoke, corresponding to $0,175,350$, and 560 seconds, respectively, of smoke dwell time in the airways and lung. Smoke was mixed at a 1:1 ratio with $100 \%$ oxygen to minimise hypoxia. Plasma and expired breath samples were collected before and at different time points $(6,12,18,24,36$, and 48 hours) after exposure. L ung and airway sections were evaluated histologically for injury and biochemically for indices of oxidative stress. Plasma thiobarbituric acid reactive substances (T BARS) were 66 and $69 \%$ higher than controls after moderate (10 units) and high (16 units) smoke exposure at 48 hours, whereas total antioxidant potential was not statistically different among groups at any time after exposure. L ung T BARS showed a dose-dependent response to smoke inhalation and were approximately 2-, 3- and 4-fold higher, respectively, than controls after exposure to 5,10 and 16 units of smoke. L ung myeloperoxidase (M PO) activity was also higher in smoke-exposed animals, and M PO activity was markedly elevated (19- and 22-fold than controls in right apical and medial lobes) in response to severe (16 units) smoke exposure. Smoke exposure also induced a dose-dependent injury to tracheo-bronchial epithelium and lung parenchyma. T he study showed that few indices of oxidative stress responded in a dose-dependent manner although most of the indices measured in the lung were affected by the highest dose of smoke (16 units), and it could not determined whether the oxidants are a cause or a consequence of the airway and lung injury associated with exposure to wood smoke.

\subsubsection{Carcinogenic effects}

In the very recent study by R eed et al. (2006) described in detail in section 6.2.2.1, lung carcinogenesis measured as either the percentage of young strain A/J mice (20 of each sex per group) with tumours (incidence) or the number of tumours per tumour-bearing mouse (multiplicity) yielded no significant differences from the control group and there was no evidence of a progressive exposure-related trend. Animals were exposed to hardwood smoke (HWS) generated from an uncertified wood stove, burning wood of mixed oak species, by whole-body inhalation ( 6 hours/day, 7 days/week) for 6 months to clean air (control) or dilutions of whole emissions based on particulate (30, 100,300 , or $1000 \mu \mathrm{g} / \mathrm{m}^{3}$ total PM ).

M umford et al. (1990b) studied mouse skin carcinogenicity of indoor coal and wood combustion emissions from homes in X uan W ei in C hina where the lung cancer mortality rate is high. Indoor air particles (less than 10 microns) were collected from a central commune where the lung cancer mortality rate is high and smoky coal is the major fuel used, and also from a south-western commune where lung cancer mortality rate is low and where wood or smokeless coal are the major fuels used. The organic extracts of the indoor particles from smoky coal, smokeless coal and wood combustion were analysed for PAH and assayed for skin tumour initiation activity and complete 
carcinogenicity in SEN CAR mice. The organic extract of the emission particles from smoky coal combustion was the most active in tumour initiation followed by smokeless coal and then wood. T he organic extract of the particles from smoky coal combustion was shown to be a potent complete carcinogen, whereas the wood extract was relatively inactive as a complete carcinogen. Smokeless coal extract was not tested for complete carcinogenicity because of inadequate supply. Eighty-eight percent of the mice treated with the smoky coal extract showed carcinomas, averaging 1.1 carcinomas per tumour-bearing mouse at the end of the 77-week study.

\subsection{In vitro studies}

T he generation of free radicals by wood smoke and cellular injuries caused by these radicals have been investigated in cultured RAW 264.7 mouse macrophage cells ( $L$ eonard et al. 2000). T he cells were exposed to liquid wood smoke generated by thermolysis of western bark (pine and fir) followed by bubbling the smoke through $10 \mathrm{ml}$ saline. The wood smoke produced significant D N A damage and was also able to cause lipid peroxidation, activate the nuclear transcription factor $(N F \kappa B)$, and enhance the release of T N F - $\alpha$ from the cells. T he results indicate that the free radicals generated by wood smoke are able to cause D N A and cellular damage and may act as a fibrogenic agent.

T he sister chromatid exchange (SCE) induction of emissions from an airtight horizontal baffled residential wood stove was investigated in $\mathrm{C}$ hinese $\mathrm{H}$ amster O vary ( $\mathrm{CHO}$ ) cells ( $\mathrm{H}$ ytonen et al. 1983). T he samples were taken under normal and starved air conditions, from burning birch and spruce separately. B oth particle phase and vapour phase were collected. All samples induced a dose-related response in SCE both with and without a metabolic activation system (rat liver microsomal fraction). T he burning conditions in the stove influenced the mutagenicity of the emissions more than the type of wood; the smoke from wood burning under starved air conditions was more than one order of magnitude more potent in inducing a significant SCE response. W ith all samples, the response in SCE induction was highest without metabolic activation.

Smoke condensates of woods used for food preservation and aromatisation in $\mathrm{N}$ igeria were tested for mutagenic activity using Salmonella typhimurium T A 98 and T A 100 (A sita et al. 1991). T he woods were: white mangrove, red mangrove, mahogany, abura, alstonia and black afara. Cigarette tar was tested for comparison. The condensates induced dose-dependent increases in the number of $\mathrm{H}$ is + revertants mainly with $\mathrm{S} 9 \mathrm{mix}$. With the exception of mahogany and cigarette smoke condensate, the smoke condensates induced more revertants/ $\mu \mathrm{g}$ condensate in T A 100 than in T A 98. T he number of revertants/ $\mu \mathrm{g}$ condensate ranged between 0.04 and 0.9 for the wood smoke condensates and was 0.12 for the cigarette smoke in T A 100. T he range was between 0.1 and 0.3 for the wood smoke condensates and 0.18 revertants/ $/ \mathrm{g}$ condensate for cigarette smoke in T A 98. T he condensates contained varying concentrations of PAH and those with higher concentrations generally showed greater mutagenic activities. H owever, the order of mutagenic potency in the bacterial strains differed from the order of PAH concentrations, which were lower than the concentrations at which they have been reported to induce mutations. When 6 of the PAH were mixed in the concentrations in which they were found in the individual condensates, the mixtures did not induce 
mutation so that the contribution of the PAH to the mutagenic activities of the condensates could not be determined.

K ubátova et al. (2004) used hot pressurised water for the fractionation at different temperatures of both the polar (low temperature) and non-polar fractions (high temperature) of diesel exhaust and wood smoke PM. N onpolar fractions from both PM sources showed strong cytotoxic responses (reduced viability) in mammalian cells with the strongest response from diesel PM . Also the polar fractions of both PM sources showed strong cytotoxic responses. T he mid-polar fraction from wood-smoke PM showed a stronger response than the identical fraction from diesel PM where only limited cytotoxicity was observed.

In a conference abstract, $\mathrm{K}$ lippel (2006) reported that PM from a wood stove operating under bad conditions contained substantially higher concentrations of PAH than diesel soot and also revealed increased toxicity in an in vitro test with lung cells from the $C$ hinese hamster. Particles from an automatic wood furnace were less toxic than diesel soot.

A recent study investigated and compared the genotoxicity and the ability to induce inflammatory mediators of nine different particle types from wood and pellets combustion, from tire-road wear and collected from an urban street and a subway station ( $K$ arlsson et al. 2006). All particles tested caused D N A damage in human lung cells ( $A 549$, C omet assay). T he three types of particles from wood combustion (old-type boiler, modern boiler, pellets) showed similar genotoxic potency and there was no significant difference between them. The subway particles were most genotoxic of the particles tested and caused typically 4-5 times more D N A damage than the other particles, likely, according to the authors, due to redox-active iron. Of the wood particles, the only sample that caused a significant increase in cytokine release was the particles from the modern wood boiler; the most potent particles to induce cytokines were those collected from an urban street.

\subsection{Summary, experimental studies}

O nly one study (Barregard et al. 2006) has been found with experimental exposure (short-term) of human volunteers ( 13 individuals) to wood smoke $P M$. T he study indicates that wood smoke particles, at levels that can be found in smoky indoor environments ( $P M_{2.5}$ levels of $240-280 \mu \mathrm{g} / \mathrm{m}^{3}$ ), seem to affect inflammation, coagulation, and possibly lipid peroxidation, factors that may be involved in the mechanisms whereby particulate air pollution affects cardiovascular morbidity and mortality.

T oxicological studies in laboratory animals suggest that PM can influence the functioning of the lung, the blood vessels and the heart. M uch of the toxicological evidence indicating the potential of PM to induce toxicity arises from direct high dose administration of PM into airways and lungs. The few inhalation studies available from experimental animals indicate that different types of PM may induce toxicity at relatively high levels. $\mathrm{N}$ ot only particles of a certain size or chemical composition are responsible for the adverse effects of PM . A dverse health effects are unlikely to be related to a single PM fraction, but more likely to a complex, eventually synergistic interaction of multiple PM components with the respiratory tract and subsequent target organs. H owever, there are preliminary indications that primary, carbonaceous PM components may be more important for adverse health 
effects than secondary components like sulphates and nitrates. Both coarse and fine particles are capable of inducing toxicity; however, whether the ultrafine PM fraction, tested at environmentally relevant levels, is also toxic, remains more uncertain.

Various animal studies have been used to elucidate the carcinogenicity of diesel exhaust. In all valid inhalation studies in rats, diesel exhaust was found to be carcinogenic at particle concentrations of $>2 \mathrm{mg} / \mathrm{m}^{3}$, corresponding to an equivalent continuous exposure of about $1 \mathrm{mg} / \mathrm{m}^{3}$. No carcinogenic effects were seen in hamsters or mice. D iesel exhaust, without the particulate fraction, administered by inhalation to rats did not show a carcinogenic potential. L ong-term inhalation of carbon black, virtually devoid of PAH, resulted in lung tumours in rats. In studies using intra-tracheal instillation, both diesel exhaust particles and carbon black induced tumours; the surface area of the carbonaceous particles appeared to be correlated with the carcinogenic potency. It is not clear whether the carcinogenicity of diesel exhaust involves D N A-reactive or non-D N A-reactive mechanisms (or a combination).

A recent review (Zelikoff et al. 2002) has addressed the adverse health effects associated with exposure to wood smoke in experimental animals. Although the effects associated with exposure to wood smoke are not as well studied as the effects of its individual components, a number of adverse health effects have been reported such as e.g. inflammation and damage to epithelial cells; inflammation has been seen both after single and repeated inhalation exposure of rats. In one study (T esfaigzi et al. 2002), minor but significant changes in the airways of rats (mild chronic inflammation and squamous metaplasia in the larynx; alveolar macrophage hyperplasia and pigmentation, and slightly thickened alveolar septae) were observed following whole-body exposure ( 3 hours/day, 5 days/week for 4 or 12 weeks) to 1 or $10 \mathrm{mg} / \mathrm{m}^{3}$ wood smoke particles.

Some studies investigating the effects of wood smoke emissions on pulmonary immunity are available. Studies in rats (exposed one hour/day for 4 days to wood smoke at $750 \mu \mathrm{g} / \mathrm{m}^{3} \mathrm{PM}_{2.5}$ ) have indicated that host defence and/or immune cell function, leading to impairment of lung clearance, is depressed in a manner similar to that produced by many of the individual wood smoke constituents (Zelikoff et al. 1995a,b). Similarly, another study (Burchiel et al. 2005) has indicated that inhalation of wood smoke ( 6 hours/day for 6 months) may be immunosuppressive to the immune system of mice at environmentally relevant exposure levels.

A very recent study (R eed et al. 2006) has summarised health effects of subchronic exposure to environmental levels (30-1000 $\mu \mathrm{g} / \mathrm{m}^{3}$ total PM ) of hardwood smoke in rats and mice exposed by inhalation for 6 months. T he results reported suggest that these concentrations of hardwood smoke present little to small hazard with respect to clinical signs, lung inflammation and cytotoxicity, blood chemistry, haematology, cardiac effects, and bacterial clearance. H owever, exposure to hardwood smoke was reported to have mild effects in mouse and rat models of asthma (Barrett et al. 2006, T esfaigzi et al. 2005) and mild effects on broncho-alveolar lavage parameters (Seagrave et al. 2005).

In the very recent study (Reed et al. 2006), lung carcinogenesis measured as either the percentage of young mice with tumours (incidence) or the number of tumours per tumour-bearing mouse (multiplicity) yielded no significant 
differences from the control group and there was no evidence of a progressive exposure-related trend.

A few in vitro studies with mammalian cells have shown that wood smoke may be associated with cytotoxicity, D N A and cellular damage, lipid peroxidation and cytokine release. F urthermore, wood smoke condensates have been shown to induce a dose-dependent increased mutagenicity in Salmonella typhimurium.

The most recent study ( $K$ arlsson et al. 2006) demonstrated that particles from wood combustion (old-type boiler, modern boiler, pellets) caused D N A damage in human lung cells (A549, C omet assay); the three types of particles showed similar genotoxic potency.

O verall, some of the available studies in experimental animals indicate that inhaled PM from wood smoke, similarly to PM in general, can cause adverse health effects in the respiratory tract and lungs such as inflammation, altered lung clearance, damage to epithelial cells, immuno-suppression, and hyperplastic lesions.

H owever, a very recent study ( $R$ eed et al. 2006) summarising the health effects of subchronic exposure to environmental levels (30-1000 $\mu \mathrm{g} / \mathrm{m}^{3}$ total PM ) of hardwood smoke in rats and mice indicates that exposure to these concentrations present little to small hazard with respect to clinical signs, lung inflammation and cytotoxicity, blood chemistry, haematology, cardiac effects, and bacterial clearance, and carcinogenic potential. H owever, parallel studies demonstrated mild exposure effects on broncho-alveolar lavage parameters and in mouse and rats models of asthma. 


\section{Risk assessment, wood smoke particles}

Risk assessment for exposure to air pollutants, including wood smoke particles, generally follows the classical paradigm of chemical risk assessment and consists of an exposure assessment, a hazard assessment, and a risk characterisation.

T he exposure to air pollutant( $s$ ) is assessed by determining the concentration of the pollutant(s) in the air and the volume of air inhaled over time, in order to define the intake dose.

The hazard assessment consists of a hazard identification, which is a qualitative description of the adverse health effects observed following exposure to the pollutant(s), and a subsequent hazard characterisation, which is a quantitative description of the dose-response relationships for the observed effects.

In the final step, the risk characterisation, the exposure and hazard assessments are integrated.

$\mathrm{H}$ owever, the risk assessment process for air pollutants varies from that for chemicals in general in two main aspects:

1) T oxicological information usually plays a confirmatory or explanatory role for air pollutants as most of the critical hazard information stems from epidemiology. T his is in contrast to the situation with chemical substances in general where toxicological information plays a major role in the hazard assessment.

2) For air pollution, adverse health effects may be noted at or close to ambient exposure levels whereas for chemical substances in general, the margins between exposures and effects levels are often larger. T hus, for some air pollutants such as PM, it will only be possible to describe dose-response functions for the associated health outcomes.

Particulate matter (PM ) in ambient air and in wood smoke is a complex mixture of multiple components ranging from a few nanometres in size to tens of micro-metres. The multiple components present in ambient air and wood smoke PM include many very toxic single constituents such as e.g. PAH, dioxin, heavy metals, and several volatile carcinogens such as formaldehyde, benzene and 1,3-butadiene. H ence, adverse health effects following inhalation of ambient air and wood smoke PM are unlikely to be related to a single PM component, but more likely related to a complex, eventually synergistic interaction of multiple components with the respiratory tract and subsequent target organs.

From the latest 10-15 years of toxicological and epidemiological research, an extensive body of evidence has been generated documenting the adverse health effects resulting from ambient air PM. T he numerous epidemiological studies show a very consistent and uniform pattern with regard to different types of health outcomes and dose-response relationships. Associations between adverse health effects and ambient air PM have typically been 
identified in relation to PM levels measured in the background urban air in general. H owever, studies analysing different fractions of PM and studies analysing specific combustion related gaseous

pollutants in addition to PM have shown that especially PM from combustion sources are important in relation to the adverse health effects.

$T$ herefore, this report mainly focuses on the adverse health effects related to PM from wood smoke.

W hen assessing the adverse health effects of wood smoke PM , there are at least two different methodological approaches that can be used:

1) To assess wood smoke PM as a part of ambient air PM and to benefit from the knowledge regarding adverse health effects from the PM in general. Especially important in this approach would be to identify epidemiological and toxicological studies in which wood smoke PM has been identified as an important source of the total PM fraction.

2) T o separate the wood smoke PM into its different constituents and perform a risk characterisation for each constituent. Although a risk characterisation in theory may be performed for wood smoke PM by using this approach, it may be very difficult to evaluate the actual health risk of wood smoke PM as an evaluation also would require knowledge about the vast amount of possible physico-chemical and toxicological interactions between the several hundreds of different constituents in the wood smoke.

Consequently, the approach chosen in this report is to assess the adverse health effects of wood smoke PM based on the current knowledge on PM in general with focus on the epidemiological studies where wood smoke PM has been identified as an important source of the total PM fraction.

\subsection{Exposure assessment}

M easurements of particulate matter (PM ) levels in ambient air in areas with many wood-burning stoves have consistently shown elevated levels of PM emissions, particularly during wintertime when wood burning is common. D ue to the size distribution of wood smoke particles essentially all will be contained in the $\mathrm{PM}_{2.5}$ fraction.

T here is only very limited information on population exposure to wood smoke particles in D enmark.

M easurements during a 6-week winter period (2002 and 2003-2004) in a $D$ anish residential area with no district heating and many wood stoves showed that the contribution from wood combustion to ambient $\mathrm{PM}_{2.5}$ was comparable to the contribution from a heavily trafficked road to $\mathrm{PM}_{2.5}$ at the sidewalk. T he average local $\mathrm{PM}_{2.5}$ contribution from wood combustion was about $4 \mu \mathrm{g} / \mathrm{m}^{3}$ ( $\mathrm{G}$ lasius et al. 2006).

In another residential area with natural gas combustion as the primary heating source and wood combustion as a secondary heating source, the average PM ${ }_{2.5}$ concentration was elevated by about $1 \mu \mathrm{g} / \mathrm{m}^{3}$ compared to background measurements during four winter weeks ( $G$ lasius et al. 2007).

A $n$ increase in annual average $\mathrm{PM}_{2.5}$ of $1 \mu \mathrm{g} / \mathrm{m}^{3}$ is a best maximum estimate of the whole population exposure based on the data from the measurements in these two residential areas. 
$M$ odel calculations have been used to estimate the $P M_{2.5}$ levels resulting from wood combustion in D enmark. T he results showed an increase in $\mathrm{PM}_{2.5}$ of 0.4 $\mu \mathrm{g} / \mathrm{m}^{3}$ during winter (O ctober- $\mathrm{M}$ arch) corresponding to an increase in annual $P M_{2.5}$ of $0.2 \mu \mathrm{g} / \mathrm{m}^{3}$ (as a best minimum estimate) for the whole $D$ anish population exposure (Palmgren et al. 2005).

In conclusion, the annual average $\mathrm{PM}_{2.5}$ exposure from wood smoke is roughly estimated to be $0.2-1 \mu \mathrm{g} / \mathrm{m}^{3}$ for the whole $D$ anish population with a best estimate of about $0.6 \mu \mathrm{g} / \mathrm{m}^{3}$. T he best estimate of about $0.6 \mu \mathrm{g} / \mathrm{m}^{3} \mathrm{PM}_{2.5}$ will be taken forward to the risk characterisation.

\subsection{Hazard assessment}

\subsubsection{Hazard identification}

\subsubsection{N on-cancer health effects, humans}

T he association of particulate air pollution with adverse health effects has long been recognised, especially in relation to respiratory and cardio-vascular diseases. N umerous studies have demonstrated that urban particulate air pollution is associated with increased mortality, primarily in the elderly and in individuals with pre-existing respiratory and/or cardiac diseases.

T he emission of particles from residential wood burning and their impact on human health has received much attention lately.

Several early studies ( $T$ able 5 ) have focused on the presence of a wood stove in the home as a risk factor. While these studies strongly suggest that there are adverse health impacts in form of more respiratory symptoms and diseases associated with wood smoke exposure, their crude exposure assessments preclude more specific conclusions.

In addition, a number of studies (T able 7) have reported associations of adverse health impacts in the airways with use of biomass fuels. All these studies are observational and very few have measured exposure directly, while a substantial proportion have not dealt with confounding. As a result, risk estimates are poorly quantified and may be biased.

A number of studies ( $T$ able 6 ) have also evaluated adverse health effects from ambient air pollution in relation to residential wood combustion in communities where wood smoke was a major, although not the only, source of ambient air particulate. T he studies indicate a consistent relationship between $\mathrm{PM}_{1}, \mathrm{PM}_{2.5}$ and/or $\mathrm{PM}_{10}$ and increased respiratory and asthmatic symptoms, and decreased lung function. T he studies have mainly focused on children, but the few studies focusing on adults as well have shown similar results. T here are also indications from several of the studies that asthmatics are a particularly sensitive group. T he studies giving an indication of the doseresponse relationship are summarised in T able 8 (section 7.2.2.1).

In conclusion, the available studies indicate that exposure to wood smoke PM is associated with the same kind of non-cancer health effects known from exposure to PM in general. 


\subsubsection{C arcinogenic effects, humans}

D uring the last decade, several cohort studies on cancer risk due to exposure to particles in the general environment have been published. Three U.S. cohort studies suggest an excess risk of lung cancer with long-term exposure to air pollution. A cohort study from the $N$ etherlands found lung cancer mortality associated with the yearly mean concentration of $\mathrm{N} \mathrm{O}_{2}$, and a $\mathrm{N}$ orwegian study found an association between lung cancer and increase in the yearly mean concentration of $\mathrm{NO}_{x}$. In these studiees $\mathrm{NO}_{2}$ and $\mathrm{NO}_{x}$ should be seen as indicators for combustion related pollutants including PM . A recent study found it plausible that known chemical carcinogens, e.g. PAHs, associated with the PM are responsible for the lung cancer risk attributable to $\mathrm{PM}_{2.5}$ exposure; however, it was also stated that it should not be excluded that $P M$ in itself is capable of causing lung cancer independent of the presence of known carcinogens.

T here is limited information regarding the human cancer risks associated with biomass air pollution. $T$ he $C$ hinese studies on an association between wood smoke exposure and lung cancer risk do not indicate an increased risk even after long-term exposure to very high levels of biomass smoke from open-fire domestic cooking. T wo more recent case-control studies from $M$ exico and Southern Brazil are suggestive of a small increased risk of lung cancer due to long-term exposure to wood smoke from cooking; however, these studies are limited by the lack of exposure assessments. The most recent case-control study found an increased risk for lung cancer among $C$ anadian women in homes with wood stove or fireplace heating and with gas or wood stove cooking facilities.

O ne study has reported a significant increase in the occurrence of both micronuclei and chromosomal aberrations in peripheral lymphocytes from Indian women cooking with bio-fuels, including wood.

In conclusion, the available studies do not provide a sufficient basis in order to evaluate whether there is an association between wood smoke exposure and increased risk of lung cancer. H owever, an excess risk of lung cancer associated with long-term exposure to particles in the general environment have been suggested and there are, for the time being, no indications that wood smoke PM should be different from ambient air PM in general regarding a carcinogenic potential. It should be noted that the International A gency for Research on Cancer (IARC 2008) has recently evaluated that indoor emissions from household combustion of biomass fuel (primarily wood) are probably carcinogenic to humans ( $G$ roup $2 A$ ).

\subsubsection{D ata from studies in experimental animals}

T oxicological studies in laboratory animals suggest that particulate matter (PM ) in general can influence the functioning of the lung, the blood vessels and the heart. The relatively few inhalation studies available indicate that different types of PM may induce toxicity at relatively high exposure levels. $\mathrm{N}$ ot only particles of a certain size or chemical composition are responsible for the adverse effects of PM . H owever, there are preliminary indications that primary, carbonaceous PM components may be more important for adverse health effects than secondary components like sulphates and nitrates. Both coarse and fine particles are capable of inducing toxicity; however, whether 
the ultrafine PM fraction, tested at environmentally relevant levels, is also toxic, remains more uncertain.

Various animal studies have been used to elucidate the carcinogenicity of diesel exhaust. In all valid inhalation studies in rats, diesel exhaust was found to be carcinogenic whereas no carcinogenic effects were seen in hamsters or mice. $D$ iesel exhaust, without the particulate fraction, administered by inhalation to rats did not show a carcinogenic potential. L ong-term inhalation of carbon black, virtually devoid of $\mathrm{PAH}$, resulted in lung tumours in rats. In studies using intra-tracheal instillation, both diesel exhaust particles and carbon black induced tumours; the surface area of the carbonaceous particles appeared to be correlated with the carcinogenic potency. It is not clear whether the carcinogenicity of diesel exhaust involves D N A-reactive or nonD N A-reactive mechanisms (or a combination).

Although the adverse health effects associated with inhalation exposure of wood smoke in experimental animals are not as well studied as the effects of its individual components, a number of adverse health effects have been reported such as e.g. inflammation and damage to epithelial cells; inflammation has been seen both after single and repeated inhalation exposure of rats. O ne study in rats investigating the effects of wood smoke on pulmonary immunity has indicated that host defence and/or immune cell function, leading to impairment of lung clearance, is depressed in a manner similar to that produced by many of the individual wood smoke constituents. Similarly, another study has indicated that wood smoke may be immunosuppressive in mice. Recent studies have reported mild effects in mouse and rat models of asthma and mild effects on broncho-alveolar lavage parameters.

A very recent study in mice did not show any hardwood smoke exposure related lung carcinogenesis measured as either the percentage of young mice with tumours (incidence) or the number of tumours per tumour-bearing mouse (multiplicity).

A few in vitro studies with mammalian cells have shown that wood smoke may be associated with cytotoxicity, D N A and cellular damage, lipid peroxidation and cytokine release. F urthermore, wood smoke condensates have been shown to induce a dose-dependent increased mutagenicity in Salmonella typhimurium. The most recent study demonstrated that particles from wood combustion caused D N A damage in human lung cells (A 549, C omet assay).

In conclusion, some of the available studies in experimental animals indicate that inhaled PM from wood smoke, similarly to PM in general, can cause adverse health effects in the respiratory tract and lungs such as inflammation, altered lung clearance, damage to epithelial cells, immuno-suppression, and hyperplastic lesions. R ecent studies have demonstrated mild exposure effects on broncho-alveolar lavage parameters and in mouse and rats models of asthma.

\subsubsection{Hazard characterisation / dose-response relationship}

\subsubsection{N on-cancer health effects, humans}

T he hazard characterisation of particulate matter (PM) in ambient air is mainly based on epidemiological studies (cohort studies and time-series 
studies). A limitation with both study designs is the exposure characterisation. T he exposure estimates for ambient PM is generally based on the particle mass determined as $\mathrm{PM}_{1}, \mathrm{PM}_{2.5}$, and/or $\mathrm{PM}_{10}$. T hus, the actual contribution from different $P M$ sources is not known. A significant limitation in this approach is the lack of exposure data for individual persons as the exposure estimates is usually based on data from a single monitoring site in the area, and assumed to be representative for all individuals in the area. A nother limitation is that most of the exposure information is on fine particles $\left(P M_{2.5}\right)$, or the sum of fine and coarse particles $\left(P M_{10}\right)$, whereas the information on ultrafine particles ( $<0.1 \mu \mathrm{m}$ in diameter) is limited.

Several time-series studies in U SA and Europe are available showing a doseresponse relationship for short-term changes in PM levels. A meta-analysis showed that an increase of $10 \mu \mathrm{g} / \mathrm{m}^{3} \mathrm{PM}_{10}$ was associated with a $0.6 \%$ increase in total mortality, a $1.3 \%$ increase in respiratory related deaths, and a $0.9 \%$ increase in cardiovascular deaths in a city area in the first days after the PM ${ }_{10}$ increase; if the observation time was extended for 40 days, the increase in total mortality was 1\%. A study in the German city Ehrfuhrt indicated that the effect of ultrafine particles on death due to cardiac and respiratory disease was comparable to the effect of $\mathrm{PM}_{2.5}$ and $\mathrm{PM}_{10}$. In a recently published update of this study, a significant association between total mortality and cardiorespiratory mortality and the number concentrations of ultrafine particles was found whereas the increased mortality in relation to particle mass $\left(P M_{10}\right)$ did not reach a significant response. A nother European study (in A msterdam, Ehrfuhrt and $\mathrm{H}$ elsinki) reported that effects on cardiac and respiratory disease correlated better with $\mathrm{PM}_{2.5}$ than with the ultrafine particles.

$T$ he available cohort studies show that a dose-response relationship in relation to long-term exposure to PM exists. T he most recent American cohort study (Pope et al. 2002) revealed a clear and significant dose-response association between mortality and $\mathrm{PM}_{2.5}$ as the mortality increased with $4 \%$ per $10 \mu \mathrm{g} / \mathrm{m}^{3}$ in $\mathrm{PM}_{2.5}$ in 1979-83 and with $6 \%$ per $10 \mu \mathrm{g} / \mathrm{m}^{3}$ in $\mathrm{PM}_{2.5}$ in 1999-2000; mortality caused by heart/lung disease was increased with $9 \%$ per $10 \mu \mathrm{g} / \mathrm{m}^{3}$ in $\mathrm{PM}_{2.5}$. A very recent study (Jerret et al. 2005) on a subset (L os Angeles area) of the A merican cohort has reported a $10 \mu \mathrm{g} / \mathrm{m}^{3}$ increase in the annual $P M_{2.5}$ level to be associated with an increase in mortality of $17 \%$. T he corresponding increase in ischaemic heart disease was 38\% and for lung cancer $46 \%$. T hus, the study on the subset of the A merican cohort found an increase in mortality that was three times higher than that reported for the entire A merican cohort in the period 1999-2000. T he increase in the subset study was considered to be due to a more accurate exposure assessment than in the prior studies. The authors also suggested that a higher contribution of traffic PM in the L os Angeles area might have resulted in the higher increased mortality.

A recently published follow-up of the D ockery et al. (1993) six cities study found an increase of $16 \%$ in the overall mortality to be associated with each 10 $\mu \mathrm{g} / \mathrm{m}^{3} \mathrm{PM}_{2.5}$ as an overall mean during the period, or an increase of $14 \%$ in relation to the annual mean of $\mathrm{PM}_{2.5}$ in the year of death ( $L$ aden et al. 2006). T he particulate air pollution had decreased from the first to the second period (1974-1989 and 1990-1998). W hen compared with the D ockery et al. (1993) study, a decrease in mortality of $27 \%$ was found for each $10 \mu \mathrm{g} / \mathrm{m}^{3}$ reduction in the $\mathrm{PM}_{2.5}$ level between the two periods.

T he most recent cohort study ( $M$ iller et al. 2007) showed a higher increased risk for cardiovascular mortality than described in the cohort studies by $L$ aden et al. (2006 - study of intercity comparisons) and Jerret et al. (2005 - study of intra-city comparisons). In the M iller et al. (2007) study, each increase of 10 $\mu \mathrm{g} / \mathrm{m}^{3} \mathrm{PM}_{2.5}$ was associated with a $24 \%$ increase in risk of cardiovascular event 
and a $76 \%$ increase of death from cardiovascular disease. A considerable higher increased risk of cardiovascular mortality ( $128 \%$ increase per $10 \mu \mathrm{g} / \mathrm{m}^{3}$ $\mathrm{PM}_{2.5}$ ) was observed within cities compared to intercity comparisons (58\% increase per $10 \mu \mathrm{g} / \mathrm{m}^{3} \mathrm{PM}_{2.5}$. .

T he studies giving an indication of the dose-response relationship for wood smoke and non-cancer health effects in humans are summarised in T able 8. The relative risk ( $R R$ ) between an increase in ambient $P M_{10}$ of $10 \mu \mathrm{g} / \mathrm{m}^{3}$ and different health outcomes varied between 1.01 and 1.12. An RR for increased asthma hospital admissions of 1.15 and 1.04 has been reported for an increase in ambient $P M_{2.5}$ of 11 and $12 \mu \mathrm{g} / \mathrm{m}^{3}$, respectively. An R R for increased asthma symptoms in children of 1.17 has been reported for an increase in ambient $\mathrm{PM}_{1}$ of $10 \mu \mathrm{g} / \mathrm{m}^{3}$.

O verall, an increased risk of experiencing adverse health effects in the respiratory tract from exposure to particles in wood smoke is associated with an increase in ambient PM (PM ${ }_{1}, \mathrm{PM}_{2.5}$ and $\mathrm{PM}_{10}$ ) of about $10 \mu \mathrm{g} / \mathrm{m}^{3}$. N one of the available studies have indicated a threshold concentration for effects. $\mathrm{H}$ owever, it should be noted that due to differences in the statistical analyses and presentation of the results in the various studies, it is difficult to compare the results from different studies.

Table 8. Relation between exposure to wood smoke and non-cancer health effects

\begin{tabular}{|c|c|c|}
\hline Exposure & Results & Reference \\
\hline $\begin{array}{l}\mathrm{PM}_{10} \text { levels below the US air quality } \\
\text { standard of } 150 \mu \mathrm{g} / \mathrm{m}^{3} \\
\mathrm{H}^{3} \text { ighest (night-time 12-hour average) } \\
\mathrm{PM}_{2.5} 195 \mu \mathrm{g} / \mathrm{m}^{3}\end{array}$ & $\begin{array}{l}\text { Decreased lung function in asthmatic } \\
\text { children associated with an increase of } \\
10 \mu \mathrm{g} / \mathrm{m}^{3} \text { in } \mathrm{PM}_{2.5}\end{array}$ & Koenig et al. (1993) \\
\hline $\begin{array}{l}\text { 24-h PM }{ }_{10} 6-103 \mu \mathrm{g} / \mathrm{m}^{3} \text {, mean } 30 \\
\mu \mathrm{g} / \mathrm{m}^{3}\end{array}$ & $\begin{array}{l}\text { Increased asthma visits (<65 years), } \\
\mathrm{RR}=1.12 \text { for a } 30 \mu \mathrm{g} / \mathrm{m}^{3} \mathrm{PM}_{10} \text { increase }\end{array}$ & $\begin{array}{l}\text { Schwartz et al. } \\
\text { (1993) }\end{array}$ \\
\hline $\begin{array}{l}24-\mathrm{h} \mathrm{PM}_{10} 9-165 \mu \mathrm{g} / \mathrm{m}^{3}, \text { mean } 61 \\
\mu \mathrm{g} / \mathrm{m}^{3}\end{array}$ & $\begin{array}{l}\text { Increased asthma visits, RR=1.43 (low } \\
\text { temperature) and } 1.11 \text { (mean } \\
\text { temperature) for a } 60 \mu \mathrm{g} / \mathrm{m}^{3} \mathrm{PM}_{10} \\
\text { increase } \\
\text { Overall RR=1.02-1.06 for a } 10 \mu \mathrm{g} / \mathrm{m}^{3} \\
\mathrm{PM}_{10} \text { increase }\end{array}$ & Lipsett et al. (1997) \\
\hline $\begin{array}{l}\text { 24-h } \mathrm{PM}_{10} \text { generally well below the } \\
\mathrm{NZ} \text { air quality guideline of } 120 \mu \mathrm{g} / \mathrm{m}^{3}\end{array}$ & $\begin{array}{l}\text { Increase in chest symptoms ( }>55 \\
\text { years), } R R=1.38\left(35 \mu \mathrm{g} / \mathrm{m}^{3} \mathrm{PM}_{10}\right. \\
\text { increase). Increased inhaler and } \\
\text { nebulizer use ( }>55 \text { years), } \mathrm{RR}=142 \text { and } \\
2.81\left(10 \mu \mathrm{g} / \mathrm{m}^{3} \mathrm{NO}_{2} \text { increase) }\right.\end{array}$ & Harré et al. (1997) \\
\hline $\begin{array}{l}\text { 24-h PM }{ }_{10} 0-159 \mu \mathrm{g} / \mathrm{m}^{3}, \text { mean } 27 \\
\mu \mathrm{g} / \mathrm{m}^{3}\end{array}$ & $\begin{array}{l}\text { For asthmatic children, increased } \\
\text { cough, } R R=1.08\left(10 \mu \mathrm{g} / \mathrm{m}^{3} \mathrm{PM}_{10}\right. \\
\text { increase }) \text { and reduction of } \mathrm{PEF}\end{array}$ & Vedal et al. (1998) \\
\hline $\begin{array}{l}\text { 24-h PM }{ }_{10} 8-70 \mu \mathrm{g} / \mathrm{m}^{3} \text {, mean } 22 \\
\mu \mathrm{g} / \mathrm{m}^{3} \\
24-\mathrm{PM}_{2.5} \text {, mean } 12 \mu \mathrm{g} / \mathrm{m}^{3}\end{array}$ & $\begin{array}{l}\text { Increased asthma hospital admissions } \\
(<18 \text { years): } \\
\text { RR=1.14 (12 } \mu \mathrm{g} / \mathrm{m}^{3} \mathrm{PM}_{10} \text { increase) } \\
\mathrm{RR}=1.15\left(11 \mu \mathrm{g} / \mathrm{m}^{3} \mathrm{PM}_{2.5} \text { increase }\right)\end{array}$ & Norris et al. (1999) \\
\hline $\begin{array}{l}\text { 24-h mean } \mathrm{PM}_{10} 31.5 \mu \mathrm{g} / \mathrm{m}^{3} \\
\text { 24-h mean } \mathrm{PM}_{2.5} 16.7 \mu \mathrm{g} / \mathrm{m}^{3}\end{array}$ & $\begin{array}{l}\text { Increased asthma hospital admissions } \\
\text { (<65 years): } \\
R R=1.05\left(19 \mu \mathrm{g} / \mathrm{m}^{3} \mathrm{PM}_{10} \text { increase }\right) \\
\mathrm{RR}=1.04\left(12 \mu \mathrm{g} / \mathrm{m}^{3} \mathrm{PM}_{2.5} \text { increase }\right)\end{array}$ & $\begin{array}{l}\text { Sheppard et al. } \\
\text { (1999) }\end{array}$ \\
\hline $\begin{array}{l}\text { 24-h PM } 10 \\
\mu \mathrm{g} / \mathrm{m}^{3} \\
24-86 \mu \mathrm{g} / \mathrm{m}^{3}, \text { mean } 25 \\
\mu \mathrm{g} / \mathrm{m}^{3}\end{array}$ & $\begin{array}{l}\text { Increased asthma symptoms in } \\
\text { children: } R R=1.17\left(10 \mu \mathrm{g} / \mathrm{m}^{3} \mathrm{PM}_{1}\right. \\
\text { increase), } \\
\mathrm{RR}=1.11\left(10 \mu \mathrm{g} / \mathrm{m}^{3} \mathrm{PM}_{10} \text { increase }\right)\end{array}$ & Yu et al. (2000) \\
\hline $\begin{array}{l}24-\mathrm{h} \mathrm{PM}_{10} 0-187 \mu \mathrm{g} / \mathrm{m}^{3} \text {, mean } 28 \\
\mu \mathrm{g} / \mathrm{m}^{3}\end{array}$ & $\begin{array}{l}\text { Increased mortality; RR=101(all } \\
\text { causes), RR=1.04 (respiratory causes) } \\
\text { for } 10 \mu \mathrm{g} / \mathrm{m}^{3} \mathrm{PM}_{10} \text { increase }\end{array}$ & Hales et al. (2000) \\
\hline
\end{tabular}




\begin{tabular}{|c|c|c|}
\hline $\begin{array}{l}\text { 24-h } \mathrm{PM}_{2.5} 2.9-25 \mu \mathrm{g} / \mathrm{m}^{3}(95 \% \mathrm{Cl}) \text {, } \\
\text { mean } 10.6 \mu \mathrm{g} / \mathrm{m}^{3} \\
\text { 24-h Total carbon } 1.4-9.4 \mu \mathrm{g} / \mathrm{m}^{3} \\
(95 \% \mathrm{Cl}), \text { mean } 4.6 \mu \mathrm{g} / \mathrm{m}^{3}\end{array}$ & $\begin{array}{l}\text { Increased respiratory emergency } \\
\text { departments visits; } R R=1013 \text { ( } 7.7 \\
\mu \mathrm{g} / \mathrm{m}^{3} \text { increase in } \mathrm{PM}{ }_{2.5} \text { ) } \\
\text { Increased respiratory emergency } \\
\text { departments visits; } R R=1023 \text { ( } 3.0 \\
\mu \mathrm{g} / \mathrm{m}^{3} \text { increase in total carbon) }\end{array}$ & $\begin{array}{l}\text { Schreuder et al. } \\
\text { (2006) }\end{array}$ \\
\hline
\end{tabular}

COPD: Chronic Obstructive Pulmonary Disease

PEF: Peak Expiratory Flow

Boman et al. (2003) have compared the results from the five wood smoke studies in which residential wood combustion was mentioned as an important air pollution source with estimations for the association between PM and health effects in the general environment (Figure 3 in section 5.1.2.2.2). All the included studies showed significant positive associations for respiratory symptoms evaluated. In comparison with the estimations concerning ambient $\mathrm{PM}$ and health effects in the general environment, the RR were even stronger in the studies in which residential wood combustion was considered a major PM source. Based on this comparison, the authors concluded that there seems to be no reason to assume that the health effects associated with PM in areas polluted with wood smoke are weaker than elsewhere.

A very recently published review ( $\mathrm{N}$ aeher et al. 2007), which is based on an extended list of references, confirms the overall picture presented by Bomann et al. (2003) as well as the present report.

F orsberg et al. (2005) analysed the impact on human health from PM levels in Sweden. F rom the PM ${ }_{10}$ levels, 5300 premature deaths per year were estimated. Of these, 3500 deaths could be attributed to the levels contributed from long range transported PM, while 1800 could be attributed to local sources in Sweden. T he fraction of premature deaths due to local sources varied strongly geographically with about $29 \%$ in the far south, due to high concentrations of long-range transported particles, to about $84 \%$ in the far north. In the northern part, wood smoke PM is the predominant source of PM .

In conclusion, the uncertainties about the actual contribution of PM from wood smoke to ambient PM preclude, for the time being, precise characterisations of specific dose-response relationships for the adverse health effects associated with exposure to wood smoke PM and whether differences exist compared to the known dose-response relationships from PM in general. T herefore, a more precise evaluation of the impact on human health of air pollution related to residential wood combustion is not possible for the time being.

H owever, the available epidemiological studies indicate that wood smoke PM does not seem to be less harmful than ambient PM in general and it is worth noting that the results in the Boman et al. (2003) review indicated that the RR were even stronger in the studies in which residential wood combustion was considered a major PM source. $\mathrm{N}$ one of the available epidemiological studies, on wood smoke PM as well as on ambient PM, have indicated a threshold concentration for effects.

\subsubsection{Carcinogenic effects, humans}

D uring the last decade, several cohort studies on cancer risk due to exposure to particles in the general environment have been published. O ne A merican study reported a rate ratio for lung cancer of 5.21 for $\mathrm{PM}_{10}$ corresponding to 
an inter-quartile range of $24 \mu \mathrm{g} / \mathrm{m}^{3}$. In another A merican study, the largest one, an increase in the yearly mean concentration of $10 \mu \mathrm{g} / \mathrm{m}^{3}$ of $P M_{2.5}$ was associated with increased lung cancer mortality $(R R=1.14)$. A cohort study from the $\mathrm{N}$ etherlands found a $25 \%$ higher lung cancer mortality associated with a $30 \mu \mathrm{g} / \mathrm{m}^{3}$ difference in yearly mean concentration of $\mathrm{N} \mathrm{O}_{2}$, and a $\mathrm{N}$ orwegian study found an adjusted risk ratio for lung cancer of 1.08 for a 10 $\mu \mathrm{g} / \mathrm{m}^{3}$ increase in yearly mean concentration of $\mathrm{NO}_{x^{*}}$

The only information available on the association between wood smoke exposure and lung cancer risk comes from a few $C$ hinese studies. T hese studies do not indicate an increased risk even after long-term exposure to very high levels of biomass smoke $\left(\mathrm{PM}_{10} 22 \mathrm{mg} / \mathrm{m}^{3}\right)$ from open-fire domestic cooking.

In conclusion, based on the available epidemiological studies, it is not possible to evaluate the lung cancer risk due to exposure to particles from wood smoke, or to particles from other combustion sources.

\subsubsection{D ata from studies in experimental animals}

M ost studies on adverse health effects of wood smoke particles in experimental animals have used relatively high exposure levels compared to the levels generally measured in the environment.

In a recent study (T esfaigzi et al. 2002), minor but significant changes in the airways of rats (mild chronic inflammation and squamous metaplasia in the larynx; alveolar macrophage hyperplasia and pigmentation, and slightly thickened alveolar septae) were observed following exposure (whole-body, 3 hours/day, 5 days/week for 4 or 12 weeks) to 1 or $10 \mathrm{mg} / \mathrm{m}^{3}$ wood smoke particles (size distribution of $63-74 \%$ in the $<1 \mu \mathrm{m}$ fraction and $26-37 \%$ in the $>1 \mu \mathrm{m}$ fraction).

A very recent study (R eed et al. 2006) has summarised health effects of subchronic exposure to environmental levels of hardwood smoke in rats and mice exposed (whole-body, 6 hours/day, 7 days/week) for 1 week or 6 months) to dilutions of whole emissions based on particulate $\left(30-1000 \mu \mathrm{g} / \mathrm{m}^{3}\right.$ total PM , mass median aerodynamic diameter of approximately $0.3 \mu \mathrm{m})$. Exposure to these concentrations presented little to small hazard with respect to clinical signs, lung inflammation and cytotoxicity, blood chemistry, haematology, cardiac effects, and bacterial clearance, and carcinogenic potential. H owever, parallel studies demonstrated mild exposure effects on broncho-alveolar lavage parameters and in mouse and rats models of asthma.

In the very recent study of exposure to environmental levels of hardwood smoke (R eed et al. 2006), lung carcinogenesis measured as either the percentage of young mice with tumours (incidence) or the number of tumours per tumour-bearing mouse (multiplicity) yielded no significant differences from the control group and there was no evidence of a progressive exposure-related trend.

D iesel exhaust has been found to be carcinogenic to rats at particle concentrations of $>2 \mathrm{mg} / \mathrm{m}^{3}$, corresponding to an equivalent continuous exposure of about $1 \mathrm{mg} / \mathrm{m}^{3}$. 


\subsection{Risk char acterisation}

In this section, the health impact of PM from wood smoke emissions will be assessed considering the impact on mortality and on hospital admissions for respiratory and cardio-vascular diseases as these health endpoints are the most well documented endpoints in quantitative terms in relation to ambient air PM exposure.

In order to assess the health impacts from the wood smoke PM, the doseresponse relationship from the epidemiological studies on ambient PM in general (i.e., the relative risk $R R$ ) is used as the available epidemiological studies indicate that wood smoke PM does not seem to be less harmful than ambient PM in general. T he increase in the RR for a health endpoint related to ambient $P M$ in general is used to estimate the increase in $R R$ for this specific health endpoint due to the contribution from wood smoke PM . T hen this RR is used to estimate the number of cases for this specific health endpoint, which is associated to wood smoke PM .

\subsubsection{Estimated wood smoke PM exposure for risk characterisation}

At present, the population exposure to wood smoke PM in D enmark cannot be estimated precisely as only few measurements have been conducted in selected residential areas with different kinds of heating. An increase in annual average $P M_{2.5}$ of $1 \mu \mathrm{g} / \mathrm{m}^{3}$ is a best maximum estimate of the whole population exposure. $T$ his is based on the data from the two measurement campaigns in D enmark.

O ne campaign showed an increase in average $P M_{2.5}$ of $4 \mu \mathrm{g} / \mathrm{m}^{3}$ during winter in a residential area with no district heating and many wood stoves ( $G$ lasius et al. 2006, Palmgren et al. 2005).

T he other campaign showed an increase in average $\mathrm{PM}_{2.5}$ of $1 \mu \mathrm{g} / \mathrm{m}^{3}$ during winter in a residential area with natural gas combustion as the primary heating source and wood combustion as a secondary heating source ( $G$ lasius et al. 2007).

In addition to the measured $\mathrm{PM}_{2.5}$ levels, model calculations have been used to estimate the $\mathrm{PM}_{2.5}$ levels resulting from the total wood combustion in D enmark. If the total $D$ anish $\mathrm{PM}_{2.5}$ emissions from wood-combustion are assumed to be distributed evenly over the whole area of D enmark, this would result in a contribution to the annual average $\mathrm{PM}_{2.5}$ of $0.2 \mu \mathrm{g} / \mathrm{m}^{3}$.

Based on the two measurement campaigns in D enmark as well as on the model calculations, the annual average $\mathrm{PM}_{2.5}$ exposure from wood smoke can be set to $0.2-1 \mu \mathrm{g} / \mathrm{m}^{3}$ as a preliminary estimate for the whole $D$ anish population with a best preliminary estimate of about $0.6 \mu \mathrm{g} / \mathrm{m}^{3}$. T he best estimate of $0.6 \mu \mathrm{g} / \mathrm{m}^{3}$ will be used as the exposure estimate in the risk characterisation.

H owever, it should be remembered that in many residential areas people are concentrated near to the local wood burning sources and thus may be exposed to considerable higher PM levels. For individuals living in residential areas with many wood burning sources, the use of the best estimate of $0.6 \mu \mathrm{g} / \mathrm{m}^{3}$ will probably underestimate the exposure to wood smoke PM. H owever, the exposure estimated are based on measurements during the winter time and 
thus, the best estimate of $0.6 \mu \mathrm{g} / \mathrm{m}^{3}$ will probably overestimate the exposure to wood smoke PM.

\subsubsection{Dose-response relationships for risk characterisation}

\subsubsection{M ortality}

For mortality, an increase in the mortality rate of $6 \%$ (95\% Cl: $2-11 \%)$ per 10 $\mu \mathrm{g} / \mathrm{m}^{3}$ increase in $\mathrm{PM}_{2.5}$ for long-term exposure is used for the risk characterisation. This dose-response relationship was concluded by $\mathrm{W} \mathrm{HO}$ (2005) by putting weight on the studies by D ockery et al. (1993), Pope et al. (1995, 2002) and Jerret et al. (2005). T his dose-response relationship has also been used for health impact assessment in connection with the $\mathrm{Clean}$ Air for Europe Programme (CA FE), (European Commission, 2005). It should be noted, however, that the most recent studies by Jerret et al. (2005) and L aden et al. (2006) found a nearly 3 times higher increase in the mortality rate (17 and $16 \%$, respectively) per $10 \mu \mathrm{g} / \mathrm{m}^{3}$ increase in $\mathrm{PM}_{2.5}$ and thus, the use of the W HO estimate (6\%) may result in an underestimation of the mortality rate.

From the W HO dose-response relationship, it can be estimated that the overall contribution of $0.6 \mu \mathrm{g} / \mathrm{m}^{3}$ of $\mathrm{PM}_{2.5}$ from wood smoke to the annual population exposure is associated with an increase in the mortality rate of $0.36 \%$ (95\% Cl: $0.12-0.66 \%$ ) as the dose-response relationship is linear.

According to Statistics D enmark (2007), the annual mortality is about 55,000 deaths. By using the increase in the mortality rate of $0.36 \%$ associated with an annual increase of $0.6 \mu \mathrm{g} / \mathrm{m}^{3}$ of $P M_{2.5}$ from wood smoke, the wood stove emissions would contribute to about 200 deaths each year (95\% Cl: 66-360). As mentioned before, this should be considered as a low estimate and the actual number of deaths due to exposure to wood smoke may be up to 2-3 times higher according to Jerret et al. (2005) and L aden et al. (2006).

\subsubsection{Respiratory diseases, hospital admissions}

\subsection{D ata from time-series studies}

Five studies have found statistically significant associations between hospital admissions from respiratory diseases and ambient air short-term PM exposure predominantly from wood smoke (see T able 8, section 7.2.2.1).

When looking at the studies where all age groups were included, an increase of $10 \mathrm{~g} / \mathrm{m}^{3}$ in $\mathrm{PM}_{10}$ was associated with a 2-6\% increase in hospital admissions ( L ipsett et al. 1997, Schwartz et al. 1993, Sheppard et al. 1999). For PM ${ }_{2.5}$ a $10 \mathrm{~g} / \mathrm{m}^{3}$ increase was associated with a 3.3\% increase in hospital admissions (Sheppard et al. 1999). Schreuder et al. (2006) found a 1.7\% increase of emergency department visits per $10 \mathrm{~g} / \mathrm{m}^{3} \mathrm{PM}_{2.5}$ (borderline significance) and a $7.7 \%$ increase per $10 \mathrm{~g} / \mathrm{m}^{3}$ measured as total carbon, which was found to be a marker for vegetative burning.

One study that only included persons below the age of 18 ( $N$ orris et al. 1999) found a considerable higher increase in hospital admissions ( $12 \%$ for $\mathrm{PM}_{10}$, $14 \%$ for $\mathrm{PM}_{2.5}$ ). As this high increase has not been confirmed in other studies and as this study only included children, this study will not be taken into account for a quantitative health impact assessment for the overall general population as children are also included in the studies where all age groups 
were included. However, it should be noted that this study supports findings in other studies indicating that children are more susceptible to ambient air PM than the general population.

T he estimated increase of 3.3\% in respiratory hospital admissions for an increase of $10 \mathrm{~g} / \mathrm{m}^{3}$ of $\mathrm{PM}_{2.5}$ from the Sheppard et al. (1999) study will be used for the risk characterisation as this pertains to $\mathrm{PM}_{2.5}$, which seems to be the most relevant measure for particle sizes from wood smoke. F urthermore, this seems also to be a plausible figure for a dose-response relationship when considering the ranges of the $\mathrm{PM}_{10}$ dose-response relationships. Further studies are needed in order to confirm whether total carbon would be a better marker for wood burning as suggested by Schreuder et al. (2006), who found an increase in emergency department visits of $7.7 \%$ per $10 \mathrm{~g} / \mathrm{m}^{3}$ total carbon in the $\mathrm{PM}_{2.5}$ fraction.

T hus an annual increase of $0.6 \mathrm{~g} / \mathrm{m}^{3}$ of $\mathrm{PM}_{2.5}$ from wood smoke emissions would lead to an increase in respiratory hospital admissions of $0.2 \%$ as the dose-response relationship is linear.

It should be noted that using an estimate for increase in respiratory hospital admissions from short-term studies in relation to an annual increase in PM most probably will underestimate the actual health impact as it has been shown in general that effects observed in relation to short-term studies are often considerable less pronounced than effects observed in relation to longterm exposure. It should also be noted that the dose-response relationships considered from rather few studies on wood smoke PM show a steeper doseresponse relationship (two to three times steeper) when compared to the doseresponse relationships observed in numerous studies in which ambient PM in general have been assessed and in which no specific wood smoke contributions have been mentioned.

In D enmark, the annual rate of hospital admission for respiratory diseases has been reported to be approximately 78,000 cases ( $R$ aaschou- $N$ ielsen et al. 2002). By using the increase in respiratory hospital admissions of $0.2 \%$ associated with an annual increase of $0.6 \mathrm{~g} / \mathrm{m}^{3}$ of $P M_{2.5}$ from wood smoke, the wood stove emissions would contribute to about 156 cases each year.

\subsection{D ata from cohort studies (long-term exposure)}

$\mathrm{N}$ o data specifically addressing respiratory diseases and long-term exposure to wood smoke have been located; however, there are data pertaining to long term exposure to PM in general.

In the CAFE health impact assessment (European Commission 2005), the data from the cohort study conducted by Abbey et al. (1995a,b) are used for assessment of respiratory disease in relation to chronic PM exposure. An annual increase of $10 \mu \mathrm{g} / \mathrm{m}^{3} \mathrm{PM}_{10}$ was found to be associated to a $7 \%$ increase in new cases of chronic bronchitis among the adult population. For $\mathrm{PM}_{2.5}$, the corresponding dose-response was a $14 \%$ increase.

$U$ sing the dose-response relationship of $14 \%$ for new cases of chronic bronchitis for an annual increase of $10 \mu \mathrm{g} / \mathrm{m}^{3}$ of $\mathrm{PM}_{2.5}$ and the base-line incidence of chronic bronchitis per year in D enmark, an annual contribution of $0.6 \mu \mathrm{g} / \mathrm{m}^{3}$ $\mathrm{PM}_{2.5}$ from wood smoke is estimated to be associated with an increase of 
$0.84 \%$ for new cases of chronic bronchitis. T his corresponds to about 60 new cases of chronic bronchitis each year. (L oft 2007).

\subsubsection{Cardio-vascular effects}

$\mathrm{N}$ o epidemiological data on wood smoke exposure in relation to cardiovascular diseases are available neither from time-series studies nor from cohort studies.

As data on cardiovascular effects from PM in general largely pertain to time series studies, estimations using these dose-response relationships would largely underestimate the impact in relation to chronic exposure. In a very recent study, however, $M$ iller et al. (2007) found a $24 \%$ increase of cardiovascular events and a 76\% increase of cardiovascular mortality per 10 $\mu \mathrm{g} / \mathrm{m}^{3} \mathrm{PM}_{2.5}$ in a subgroup of women above the age of 50 years and without previous cardiovascular disease. T he use of this dose-response relationship in relation to the general $D$ anish population is difficult due to the rather specific selection of the study group for this study. However, although not specifically quantified, it could be concluded based on the high increased risks for cardiovascular events (coronary heart disease, cerebro-vascular disease, myocardial infarction, coronary re-vascularisation, stroke) and cardiovascular mortality found in the M iller et al. (2007) study that even an increase of 0.6 $\mu \mathrm{g} / \mathrm{m}^{3} \mathrm{PM}_{2.5}$ would have a significant health impact for the $D$ anish population with respect to cardiovascular events and mortality.

\subsubsection{Conclusions}

Based on an increase in the annual population exposure of $0.6 \mathrm{~g} / \mathrm{m}^{3} \mathrm{PM}_{2.5}$ from wood smoke emissions and the dose-response relationships considered for specific health outcomes, about 200 premature deaths, about 156 respiratory hospital admissions and about 60 new cases of chronic bronchitis can be estimated for the $D$ anish population.

It should be noted that this preliminary health impact assessment is limited by the poor exposure data available as well as by the absence of specific doseresponse relationships for the health impacts due to long-term exposure to wood smoke PM. However, it should be noted that the approach taken to assess the health impacts for wood smoke PM is in general considered to underestimate the health impacts as recently published dose-response relationships for mortality indicate a 2-3 times higher dose-response relationship compared to the WHO (2005) dose-response relationship used in our assessments. 


\section{Conclusions}

T he number of residential wood stoves in D enmark has increased during the latest years and it has been estimated that there in 2005 were about 551,000 wood stoves and about 48,000 wood boilers in D enmark. M easurements of particulate matter (PM) levels in ambient air in areas with many wood stoves have consistently shown elevated levels, particularly during wintertime when wood burning is common. R ecent results have shown that the particle emission from residential wood stoves is an important source of particles in ambient air pollution in D enmark. D ue to the size distribution of wood smoke particles essentially all will be contained in the $\mathrm{PM}_{2.5}$ fraction. It has been estimated that about 17,665 tonnes $\mathrm{PM}_{2.5}$ per year (2005) in D enmark come from residential wood combustion.

\subsection{Expo sure assessment, wood smoke PM}

At present, the population exposure to wood smoke PM in D enmark cannot be estimated precisely as only few measurements have been conducted in selected residential areas with different kinds of heating.

Based on the data from the two measurement campaigns in D enmark, an increase in annual average $\mathrm{PM}_{2.5}$ of $1 \mu \mathrm{g} / \mathrm{m}^{3}$ is a best maximum estimate of the whole population exposure. In addition to the measured $\mathrm{PM}_{2.5}$ levels, model calculations have estimated an increase in $\mathrm{PM}_{2.5}$ of $0.4 \mu \mathrm{g} / \mathrm{m}^{3}$ during winter ( $O$ ctober- $M$ arch) corresponding to an increase in annual $P_{2.5}$ of $0.2 \mu \mathrm{g} / \mathrm{m}^{3}$ as a best minimum estimate.

Based on these data, the annual average $\mathrm{PM}_{2.5}$ exposure from wood smoke can be estimated to $0.2-1 \mu \mathrm{g} / \mathrm{m}^{3}$ as a preliminary estimate for the whole $D$ anish population with a best estimate of about $0.6 \mu \mathrm{g} / \mathrm{m}^{3}$. The best estimate of 0.6 $\mu \mathrm{g} / \mathrm{m}^{3}$ has been used as the exposure estimate in the risk characterisation.

\subsection{Hazard assessment, wood smoke PM}

A number of epidemiological studies, which have evaluated adverse health effects from ambient air pollution in relation to residential wood combustion, indicate a consistent relationship between PM and increased incidences for different health endpoints. O verall, an increased risk of experiencing adverse health effects in the respiratory tract from exposure to particles in wood smoke was associated with an increase in ambient PM ( $P M_{1}, \mathrm{PM}_{2.5}$ and $\left.\mathrm{PM}_{10}\right)$ of about $10 \mu \mathrm{g} / \mathrm{m}^{3}$.

Boman et al. (2003) have compared the results from five epidemiological studies, in which residential wood combustion was mentioned as an important air pollution source, with estimations for the association between PM and health effects in the general environment. Based on this comparison, the authors concluded that there seems to be no reason to assume that the health effects associated with PM in areas polluted with wood smoke are weaker than elsewhere. 
A very recently published review ( $N$ aeher et al. 2007), which is based on an extended list of references, confirms the overall picture presented by Bomann et al. (2003) as well as the present report.

$\mathrm{N}$ one of the available epidemiological studies, on wood smoke PM as well as on ambient PM, have indicated a threshold concentration for effects.

T he available epidemiological studies do not provide a sufficient basis in order to evaluate the lung cancer risk due to exposure to particles from wood smoke, or to particles from other combustion sources.

Some studies in experimental animals indicate that inhaled PM from wood smoke, similarly to PM in general, can cause adverse health effects in the respiratory tract and the lungs. $M$ ost studies on adverse health effects of wood smoke particles in experimental animals have used relatively high exposure levels compared to the levels generally measured in the environment. $\mathrm{H}$ owever, two recent studies have reported only minor respiratory effects following subchronic exposure to environmental levels ( $30-1000 \mu \mathrm{g} / \mathrm{m}^{3}$ total $P M$, particle size $<1 \mu \mathrm{m}$ for the major part of the particles); the most recent study indicates that exposure to these concentrations presented little to small hazard with respect to clinical signs, lung inflammation and cytotoxicity, blood chemistry, haematology, cardiac effects, and bacterial clearance, and carcinogenic potential.

The uncertainties about the actual contribution of PM from wood smoke to ambient PM preclude, for the time being, precise characterisations of specific dose-response relationships for the adverse health effects associated with exposure to wood smoke PM , and whether differences exist for dose-response relationships for wood smoke PM compared to the known dose-response relationships for ambient PM in general. T herefore, a more precise evaluation of the impact on human health of air pollution related to wood combustion is not possible for the time being.

\subsection{Risk ch ar acterisation, wood smo ke PM}

T he health impact of PM from wood smoke emissions in D enmark has been assessed for mortality, and for hospital admissions for respiratory and cardiovascular diseases based on the known dose-response relationships for ambient PM in general as assessed from the available epidemiological studies.

F rom the estimated increase of $6 \%(95 \% \mathrm{Cl}: 2-11 \%)$ in the mortality rate for an increase of $10 \mathrm{~g} / \mathrm{m}^{3}$ of $\mathrm{PM}_{2.5}$ as concluded by W HO (2005), the overall contribution of $0.6 \mathrm{~g} / \mathrm{m}^{3}$ of $P M_{2.5}$ from wood smoke to the annual population exposure is estimated to be associated with an increase in the mortality rate of $0.36 \%(95 \% \mathrm{Cl}: 0.12-0.66 \%)$. T his increase in mortality rate corresponds to about 200 deaths each year (95\% Cl: 66-360).

From the estimated increase of $3.3 \%$ in respiratory hospital admissions (data from time-series studies) for an increase of $10 \mathrm{~g} / \mathrm{m}^{3}$ of $\mathrm{PM}_{2.5}$ from the Sheppard et al. (1999) study, the overall contribution of $0.6 \mathrm{~g} / \mathrm{m}^{3}$ of $\mathrm{PM}_{2.5}$ from wood smoke to the annual population exposure is estimated to be associated with an increase in respiratory hospital admissions of $0.2 \%$. T his increase in respiratory hospital admissions corresponds to about 156 cases each year. 
From the estimated increase of $14 \%$ for new cases of chronic bronchitis for an annual increase of $10 \mathrm{~g} / \mathrm{m}^{3}$ of $\mathrm{PM}_{2.5}$ as assessed by the European Commission (2005), the overall contribution of $0.6 \mathrm{~g} / \mathrm{m}^{3}$ of $P M_{2.5}$ from wood smoke to the annual population exposure is estimated to be associated with an increase of $0.84 \%$ for new cases of chronic bronchitis. This corresponds to about 60 new cases of chronic bronchitis each year.

$\mathrm{N}$ o epidemiological data on wood smoke exposure in relation to cardiovascular diseases are available neither from time-series studies nor from cohort studies. H owever, the high increased risks for cardiovascular events (coronary heart disease, cerebro-vascular disease, myocardial infarction, coronary re-vascularisation, stroke) and cardiovascular mortality found in a very recent study by $\mathrm{M}$ iller et al. (2007) in a subgroup of women (above the age of 50 years and without previous cardiovascular disease) in relation to long-term particle exposure ( general ambient air PM ) indicate that even an annual increase of $0.6 \mu \mathrm{g} / \mathrm{m}^{3} \mathrm{PM}_{2.5}$ would have a significant health impact for the $D$ anish population with respect to cardiovascular events and mortality. It should be noted, however, that due to the specific design of this study a general health impact assessment for the whole population cannot be made.

It should be remembered that this preliminary health impact assessment of wood smoke PM is hampered by the limited exposure data available as well as by the absence of specific dose-response relationships for the selected health impacts due to long-term exposure to wood smoke PM. It should also be noted that the approach taken to assess the selected health impacts for wood smoke PM is in general considered to underestimate the health impacts may result in underestimations as the dose-response relationship for mortality most likely is underestimated. 


\section{Gaps of knowledge}

As can be seen from the previous chapters in this report, limited data are available for a more precise health impact assessment of wood smoke PM . In this chapter, the most essential data gaps are indicated.

\subsection{Characterisation of wood smoke particles}

T he information on detailed physical and chemical characterisations of the particle emissions from different combustion technologies, including wood combustion, is still limited. In addition, any specific particle properties or components responsible for the adverse health effects related to the particle emissions have not yet been identified; however, the importance of characterising particle properties other than mass concentration, like chemical composition, particle size, and number concentration, has been emphasised. F urthermore, there is a lack of knowledge on particle properties, including health aspects, in relation to the different phases of the combustion cycle and type of combustion device.

T hus, more data are needed in order to provide a more precise characterisation of wood smoke PM in D enmark as well as a more precise characterisation of the wood smoke composition in general.

\subsection{Exposure assessment}

At present, the population exposure to wood smoke PM in D enmark cannot be estimated precisely as only few measurements have been conducted in selected residential areas with different kinds of heating.

T hus, more studies are needed in order to provide a more precise assessment of the population exposure to wood smoke PM in D enmark. T his pertain both to a better description of exposure in areas where wood burning is dominant as well as exposure in areas more distant from the source.

In such studies, measurements of chemical markers for wood smoke such as e.g., levoglucosan could be relevant in order to evaluate the contribution of wood smoke PM to the ambient general PM .

Since people spend a majority of their time indoors, it is important to investigate indoor exposure to wood smoke particles in order to evaluate the integrated exposure from both in-house combustion devices and background levels.

\subsection{Hazar d assessment / risk characterisation}

A number of epidemiological studies, which have evaluated adverse health effects from ambient air pollution in relation to residential wood combustion, indicate an increased risk of experiencing adverse health effects in the respiratory tract from exposure to wood smoke PM. H owever, no 
epidemiological data on wood smoke exposure in relation to cardio-vascular diseases, or overall mortality are available. In addition, the available epidemiological studies do not provide a sufficient basis in order to evaluate the lung cancer risk due to exposure to wood smoke PM .

Precise characterisations of specific dose-response relationships for the adverse health effects associated with exposure to wood smoke PM cannot be performed based on the available epidemiological studies predominantly because of the uncertainties about the actual contribution of wood smoke PM to ambient PM in general. Similarly, whether differences exist for doseresponse relationships for wood smoke PM compared to the known doseresponse relationships for ambient PM in general cannot be assessed.

T hus, more data are needed in order to provide a more precise assessment of long-term exposure of wood smoke exposure on morbidity and mortality, including a more precise characterisation of specific dose-response relationships for the various adverse health effects.

It might thus be relevant to investigate the relationship between exposure to wood smoke PM in a specific residential area with many wood stoves and the health outcomes in the population living in this specific residential area.

\subsection{Mode of action}

T he underlying mechanisms of particle toxicity are not fully understood; however, the understanding of effects on the respiratory and cardiovascular system and on tumour development has improved during the last years.

T hus, there is still a need for further experimental studies aiming at understanding the effects and underlying mechanisms of wood smoke exposure in order to assess human health risks.

\subsection{Recommen dations}

$M$ ore information is needed for a more precise health impact assessment of wood smoke PM in D enmark, particularly in relation to assess the exposure to wood smoke PM in the general population as well as to assess the long-term exposure of wood smoke PM on morbidity and mortality including a characterisation of the specific dose-response relationships for the various adverse health effects related to wood smoke PM exposure.

It might thus be recommended to conduct one or more studies in a selected residential area with many wood stoves aiming at:

- Assess the exposure to wood smoke PM in the population living in the selected residential area, including measurements of chemical markers for wood smoke in order to evaluate the contribution of wood smoke PM to the ambient general PM in the selected residential area

- Characterise wood smoke PM as well as wood smoke composition in the selected residential area

- Investigate indoor exposure to wood smoke

- Investigate the relationship between exposure to wood smoke PM and the health outcomes in the population living in the selected residential 
area, including a characterisation of the specific dose-response relationships for the various adverse health effects related to wood smoke PM exposure

In addition, there is still a need for further experimental studies aiming at:

- U nderstanding the effects and underlying mechanisms of wood smoke exposure in order to evaluate the implication in relation to human health risks

- Investigate chemical and physical particle properties as well as health effects, in relation to the different phases of the combustion cycle and type of combustion device including modern stoves. 


\section{References}

A bbey DE, H wang BL, Burchette RJ, Vancuren T and M ills PK (1995a). Estimated long-term ambient concentrations of $\mathrm{PM}_{10}$ and development of respiratory symptoms in a non-smoking population. A rch Env $\mathrm{H}$ ealth 50 , 139-152.

A bbey DE, O stro BE, Petersen F and Burchette RJ (1995b). Chronic respiratory symptoms associated with estimated long-term ambient concentrations of fine particulates less than 2.5 micron in aerodynamic diameter $\left(\mathrm{PM}_{2.5}\right)$ and other air pollutants. J Exposure A nal Environ Epid 5, 137-159.

A nderson $\mathrm{HR}, \mathrm{A}$ tkinson $\mathrm{RW}$, Peacock J, $M$ arston $\mathrm{L}$ and $\mathrm{K}$ onstantinou $\mathrm{K}$ (2004). M eta-analysis of time-series studies and panel studies of particulate matter and ozone. Report of a WHO task group. W orld H ealth Organization.

A sita A O, M atsui M , N ohmi T, M atsuoka A, H ayashi M, I shidate M Jr, Sofuni T , K oyano $M$ and $M$ atsushita $H$ (1991). M utagenicity of wood smoke condensates in the Salmonella/microsome assay. M utat R es 264, 7-14.

Atkinson RW, A nderson HR, Sunyer J, Ayres J, Baccini M, Vonk JM, Boumghar A, Forastiere F, Forsberg B, T ouloumi G, Schwartz J and $K$ atsouyanni $K$ (2001). A cute effects of particulate air pollution on respiratory admissions: results from APHEA 2 project. Air Pollution and $\mathrm{H}$ ealth: a European A pproach. Am J R espir C rit Care M ed 164, 1860-1866.

Barregard L, Sällsten G, G ustafson P, Andersson L, Johansson L, Basu S and Stigendal $L$ (2006). Experimental exposure to wood-smoke particles in healthy humans: Effects on markers of inflammation, coagulation, and lipid peroxidation. Inhal T oxicol 18, 845-853.

Barrett EG , H enson RD, Seilkop SK, M CD onald JD and Reed M D (2006). Effects of hardwood smoke exposure on allergic airway inflammation in mice. Inhal T oxicol 18, 33-43.

Beeson W L, Abbey DE and K nutsen SF (1998). L ong-term concentrations of ambient air pollutants and incident lung cancer in $C$ alifornia adults: results from the AH SM OG study. Adventist Health Study on Smog. Environ Health Perspect 106, 813-823.

Bhattacharyya SN , D ubick M A, Y antis LD, Enriquez JI, Buchanan K C, Batra SK and Smiley RA (2004). In vivo effect of wood smoke on the expression of two mucin genes in rat airways. Inflammation $28,67-76$.

BH M (2003). Biobränsle-Hälsa-M iljö, ett ST EM -projekt. Preliminär slutrapport 16 juli 2003, sammenfattning.

http://www.itm.su.se/bhm/rapporter/slutrapport_sammanfattning_prel.pdf

Bohning DE, Atkins $\mathrm{HL}$ and C ohn SH (1982). L ong-term particle clearance in man: normal and impaired. Ann O ccup Hyg 26, 259-271. 
Boman BC, Forsberg AB and Jarvholm BG (2003). Adverse health effects from ambient air pollution in relation to residential wood combustion in modern society. Scand J W ork Environ H ealth 29, 251-260.

Boman C, N ordin A, Boström D and Öhman M (2004). C haracterization of inorganic particulate matter from residential combustion of pelletized biomass fuels. Energy Fuels 18, 338-348.

B rizio-M olteni L, Piano G, Rice PL, W arpeha R, Fresco R, Solliday N H and M olteni A (1984). Effect of wood combustion smoke inhalation on angiotensin-1-converting enzyme in the dog. Ann Clin L ab Sci 14, 381-389.

Browning K G, K oenig JQ, Checkoway H, L arson T V and Pierson W (1990). A questionnaire study of respiratory health in areas of high and low ambient wood smoke pollution. Pediatric A sthma Allergy Immunol 4, 183-191.

Bruce N, Perez-Padilla R and Albalak R (2000). Indoor air pollution in developing countries: a major environmental and public health challenge. Bull W orld Health Organ 78, 1078-1092.

Brunekreef B and H olgate ST (2002). Air pollution and health. L ancet 360 , 1233-1242.

Burchiel SW, L auer FT , D unaway SL , Zawadzki J, M CD onald JD and Reed M D (2005). $H$ ardwood smoke alters murine splenic $T$ cell responses to mitogens following a 6-month whole body inhalation exposure. Toxicol Appl Pharmacol 202, 229-236.

CAFE CBA (2005). Baseline A nalysis 2000 to 2020. Service Contract for C arrying out C ost-Benefit A nalysis of Air Q uality R elated Issues, in particular in the Clean Air for Europe (C AFE) Programme. January 2005.

http://www.iiasa.ac.at/docs/H OT P/M ar05/cafe-cba-baseline-results.pdf

Chapman RS, M umford JL, H arris D B, He ZZ, Jiang WZ and Y ang RD (1988). T he epidemiology of lung cancer in $X$ uan W ei, $C$ hina: current progress, issues, and research strategies. Arch Environ H ealth 43, 180-185.

Clancy L, G oodman P, Sinclair H and D ockery DW (2002). Effect of airpollution control on death rates in D ublin, I reland: an intervention study. L ancet 360, 1210-1214.

Collings D A, Sithole SD and M artin K S (1990). Indoor wood smoke pollution causing lower respiratory disease in children. T rop D oct 20, 151155.

D emarest G B, H udson LD and Altman L C (1979). Impaired alveolar macrophage chemotaxis in patients with acute smoke inhalation. A m R ev Respir D is 119, 279-286.

D ennis RJ, M aldonado D, N orman S, Baena E and M artinez G (1996). W ood smoke exposure and risk for obstructive airways disease among women. Chest 109, 115-119. 
D ockery D W , Pope CA III, X U X, Spengler JD, W are JH, Fay M E, Ferris BG Jr. and Speizer FE (1993). An association between air pollution and mortality in six U.S. cities. N Engl J M ed 329, 1753-1759.

D ybing $E$ and T otlandsdal AI (2004) eds. Air pollution and the risks to human health - a toxicological perspective. AIR NET W ork G roup 3 T oxicology.

http://airnet.iras.uu.nl/

EHC (1996). D iesel fuel and exhaust emissions. Environmental $\mathrm{H}$ ealth C riteria 171. International Programme on C hemical Safety, W orld H ealth Organization.

Ellegard A (1996). C ooking fuel smoke and respiratory symptoms among women in low-income areas in M aputo. Environ Health Perspect 104, 980985.

Eisner M D , Y elin EH, K atz PP, Earnest G and Blanc PD (2002). Exposure to indoor combustion and adult asthma outcomes: environmental tobacco smoke, gas stoves, and wood smoke. Thorax 57, 973-978.

European Commission (2005). M ethodology for the Cost-B enefit analysis for CAFÉ: Volume 2: H ealth Impact A ssessment.

http://ec.europa.eu/environment/air/cafe/pdf/cba_methodology_vol2.pdf

EU (2005). Proposal for a D irective of the European Parliament and of the C ouncil on ambient air quality and cleaner air for Europe. Presented by the Commission Brussels 21.9.2005, Provisional Version 2005/0183 (C OD) http://ec.europa.eu/environment/air/cafe/pdf/cafe_dir_en.pdf

Evald A (2006). Brændeforbrug i D anmark. En undersøgelse af antallet af og brændeforbruget i brændeovne, pejse, masseovne og brændekedler i danske boliger og sommerhuse. F orce T echnology, September 2006. http://www.ens.dk/graphics/Energi_i_tal_og_kort/BF_2005_Rapport.pdf

Fairley D (1990). T he relationship of daily mortality to suspended particulates in Santa Clara C ounty, 1980-1986. Environ H ealth Perspect 89, 159-168.

Fick RB Jr, Paul ES, M errill WW, R eynolds HY and L oke JS (1984). Alterations in the antibacterial properties of rabbit pulmonary macrophages exposed to wood smoke. Am Rev Respir D is 129, 76-81.

Forsberg $\mathrm{B}, \mathrm{H}$ ansson $\mathrm{HC}$, Johansson $\mathrm{C}$, A reskoug $\mathrm{H}$, Persson $\mathrm{K}$ and Jarvholm $B$ (2005). C omparative health impact assessment of local and regional particulate air pollutants in Scandinavia. A mbio 34, 11-19.

G erde $P$, M uggenburg BA, L undborg $M$ and $D$ ahl $A R$ (2001). T he rapid alveolar absorption of diesel soot-adsorbed benzo[a]pyrene: bioavailability, metabolism and dosimetry of an inhaled particle-borne carcinogen.

Carcinogenesis 22, 741-749.

G lasius M, Vikelsøe J, Bossi R, Andersen HV, H olst J, Johansen E and Schleicher O (2005). D ioxin, PAH og partikler fra brændeovne. NERI T ecnical Report N o. 212. 
G lasius $M, K$ etzel $M, W$ åhlin $P$, Jensen $B, M$ ønster J, Berkowicz R and Palmgren $F$ (2006). Impact of wood combustion on particle levels in a residential area in D enmark. A tmosph Environ 40, 7115-7124.

G lasius $M$, K onggaard P, Stubkjær J, B ossi R, H ertel $O$, K etzel $M$, W åhlin P, Schleicher $O$ and Palmgren $F$ (2007). Partikler og organiske forbindelser fra træfyring - nye undersøgelser af udslip og koncentrationer. R esearch $\mathrm{N}$ otes no. 235, N ational Environmental R esearch Institute, R oskilde, D enmark.

H ales S, Salmond C, T own G I, K jellstrom T and W oodward A (2000). D aily mortality in relation to weather and air pollution in C hristchurch, $\mathrm{N}$ ew Zealand. A ust N Z J Public H ealth 24, 89-91.

H arre ES, Price PD, Ayrey RB, T oop LJ, M artin IR and T own GI (1997). R espiratory effects of air pollution in chronic obstructive pulmonary disease: a three month prospective study. T horax 52, 1040-1044.

$\mathrm{H}$ arrison R M , Smith DJ and K ibble AJ (2004). What is responsible for the carcinogenicity of PM 2.5? O ccup Environ M ed 61, 799-805.

de $\mathrm{H}$ artog J, $\mathrm{H}$ oek $\mathrm{G}$, Peters $\mathrm{A}$, T imonen $\mathrm{KL}$, I bald-M ulli A, B runekreef $\mathrm{B}$, $\mathrm{H}$ einrich J, T iittanen $\mathrm{P}$, van $\mathrm{W}$ ijnen $\mathrm{JH}$, $K$ reyling $\mathrm{W}, \mathrm{K}$ ulmala $\mathrm{M}$ and Pekkanen J (2003). Effects of fine and ultrafine particles on cardiorespiratory symptoms in elderly subjects with coronary heart disease: the U LT RA study. Am J Epidemiol 157, 613-623.

H einrich U (1994). C arcinogenic effects of solid particles. In: M ohr U, D ungworth, $M$ auderly J and $O$ berdörster $G$ (eds.) T oxic and carcinogenic effects of solid particles in the respiratory tract. International L ife Science Institute Press, W ashington DC .

$\mathrm{H}$ einrich $\mathrm{U}$, Peters $\mathrm{L}, \mathrm{C}$ reutzenberg $\mathrm{O}, \mathrm{D}$ asenbrock $\mathrm{C}$ and $\mathrm{H}$ oymann $\mathrm{H}$ (1994). Inhalation exposure of rats to tar/pitch condensation aerosol or carbon black alone or in combination with irritant gases. In: M ohr U, D ungworth D, M auderly J and O berdörster G (eds.) T oxic and carcinogenic effects of solid particles in the respiratory tract. International L ife Sciences Institute Press, W ashington DC.

H enderson RF, Pickrell JA, Jones RK, Sun JD, Benson JM , M auderly JL and M cC lellan RO (1988). Response of rodents to inhaled diluted diesel exhaust: biochemical and cytological changes in bronchoalveolar lavage fluid and in lung tissue. Fundam Appl T oxicol 11, 546-567.

H enriksen T C, Illerup JB and N ielsen O-K (2006). D ioxin Air Emission Inventory 1990-2004. T echnical R eport no. 602. N ational Environmental Research Institute, R oskilde, D enmark.

H ernandez-G arduno E, Brauer M, Perez-N eria J and Vedal S (2004). W ood smoke exposure and lung adenocarcinoma in non-smoking $M$ exican women. Int J T uberc L ung D is 8, 377-383.

H oek G, B runekreef B, G oldbohm S, Fischer P and van den B randt PA (2002). A ssociation between mortality and indicators of traffic-related air pollution in the N etherlands: a cohort study. L ancet 360, 1203-1209. 
H onicky RE, O sborne JS III and A kpom CA (1985). Symptoms of respiratory illness in young children and the use of wood-burning stoves for indoor heating. Pediatrics 75, 587-593.

H ytonen S, Alfheim I and Sorsa M (1983). Effect of emissions from residential wood stoves on SCE induction in $\mathrm{CHO}$ cells. M utat Res 118, 6975.

IARC (1996). C arbon black. In: IARC M onographs on the evaluation of carcinogenic risks to humans, V olume 65, 149-262.

IARC 2008). H ousehold combustion of solid fuels. W ebsite checked 070208. http://monographs.iarc.fr/E N G /M eetings/95-coal-biomass.pdf

Illerup JB and N ielsen M (2004). Improved PM emissions inventory for residential wood combustion. Proceedings of the $\mathrm{PM}$ emission inventories scientific workshop, L ago M aggiora, Italy, 2004.

IRCP (1994). ICR P Publication 66: H uman Respiratory T ract M odel for R adiological Protection. A nnals of the International Commission on Radiological Protection 24/1-3.

Jakab GJ (1993). T he toxicologic interactions resulting from inhalation of carbon black and acrolein on pulmonary antibacterial and antiviral defenses. T oxicol Appl Pharmacol 121, 167-175.

Jensen K A, K ofoed-Sørensen V and Clausen PA (2005). T he indoor and outdoor concentrations of particulate air pollution and PA H s in different size fractions and assessment of exposure and health impacts in the $C$ openhagen population. M iljøprojekt N o. 1003.

Jerret $M$, Burnett $R T$, $M$ a $R$, Pope $C A$, K rewski $D$, N ewbold $K B$, T hurston G, Shi Y , Finkelstein N , C alle EE and T hun M J (2005). Spatial analysis of air pollution and mortality in L os A ngeles. Epidemiol 16, 727-736.

Johansson J, M odig L and Forsber B (2004). Besvärsförekomst i vedeldningsbelastede tätorter i N orbotten och V ästerbotten. Slutrapport för ST EM - projekt 21623-1.

http://www.itm.su.se/bhm/rapporter/halsa/216231del1.pdf

$K$ arlsson $H L$, L jungman $A G$, $L$ indbom J and $M$ öller $L$ (2006). C omparison of genotoxic and inflammatory effects of particles generated by wood combustion, a road simulator and collected from street and subway. T oxicol L ett 165, 203-211.

K lippel N (2006) Particle emissions from residential wood combustion-design and operation conditions determine health impacts. $10^{\text {th }} \mathrm{ET} \mathrm{H}$ C onference on combustion generated nanoparticles, Zürich 21-23 A ugust 2006, abstract $p$ 26.

K naapen AM , Borm PJA, A lbrecht C and Schins R PF (2004). M ini R eview: Inhaled particles and lung cancer. Part A: M echanisms. Int J Cancer 109, 799-809. 
K ocbach A, L i Y, Y ttri K E, C assee FR, Schwarze and N amork E (2006). Physicochemical characterisation of combustion particles from vehicle exhaust and residential wood smoke. Particle Fibre T oxicol 3, 1-10.

K oenig JQ, Larson T V, H anley Q S, R ebolledo V, D umler K, Checkoway H, W ang SZ, L in D and Pierson WE (1993). Pulmonary function changes in children associated with fine particulate matter. Environ Res 63, 26-38.

K ubátova A, Steckler T S, G allagher JR, H awthorne SB and Picklo M J (2004). T oxicity of wide-range polarity fractions from wood smoke and diesel exhaust particulate obtained using hot pressrized water. Environ T oxicol Chem 23, 2243-2250.

K ünzli N, K aiser R, M edina S, Studnicka M, Chanel O, Fillinger $P$, H erry $M$, H orak Jr F, Puybonnieux-T exier V, Q uénel P, Schneider J, Seethaler R, Vergnaud J-C and Sommer H (2000). Public-health impact of outdoor and traffic-related air pollution: a European assessment. L ancet 356, 795-801.

L aden F, Schwartz J, Speizer FE and D ockery DW (2006). Reduction in fine particulate air pollution and mortality. A m J Respir C rit C are M ed 173, 667672.

L arson TV and K oenig JQ (1994). W ood smoke: emissions and non-cancer respiratory effects. Ann Rev Public Health 15, 133-156.

L eonard SS, Wang S, Shi X, Jordan BS, C astranova V and D ubick M A (2000). W ood smoke particles generate free radicals and cause lipid peroxidation, D N A damage, N F kappaB activation and T N F-alpha release in macrophages. T oxicology 150, 147-157.

L evesqu B, Allaire S, G auvin D, K outrakis P, G ingras S, R hainds M , Prud $\mathrm{H}$ omme $\mathrm{H}$ and D uchesne JF (2001). Wood-burning appliances and indoor air quality. Sci T otal Environ 281, 47-62.

L iang CK, Q uan NY, C ao SR, HeXZ and M a F (1988). N atural inhalation exposure to coal smoke and wood smoke induces lung cancer in mice and rats. Biomed Environ Sci 1, 42-50.

Lippmann M and Albert RE (1969). T he effect of particle size on the regional deposition of inhaled aerosols in the human respiratory tract. A m Ind H yg Assoc J 30, 257-275.

L ippmann M and Schlesinger R B (1984). Interspecies comparisons of particle deposition and mucociliary clearance in tracheobronchial airways. J T oxicol Environ Health 13, 441-469.

Lipsett M , H urley S and O stro B (1997). Air pollution and emergency room visits for asthma in Santa Clara C ounty, C alifornia. Environ H ealth Perspect 105, 216-222.

L oft S (2007). L angtidseffekter af partikler fra brændeovne: hjertekar sygdom og kræft. Præsentation ved M iljø- og Planlægningsudvalgets eksperthøring om samspillet mellem brænderøgsforurening og folkesundhed, Christiansborg $\mathrm{d}$. 25. april 2007. 
L ogan W P (1953). M ortality in the L ondon fog incident, 1952. L ancet 1 , 336-338.

Loke J, Paul E, Virgulto JA and Smith G J (1984). Rabbit lung after acute smoke inhalation. Cellular responses and scanning electron microscopy. Arch Surg 119, 956-959.

M ahalanabis D, G upta S, Paul D, G upta A, L ahiri M and K haled M A (2002). Risk factors for pneumonia in infants and young children and the role of solid fuel for cooking: a case-control study. E pidemiol Infect 129, 65-71.

$M$ atson $U$ (2005). Indoor and outdoor concentrations of ultrafine particles in some Scandinavian rural and urban areas. Sci T otal Environ 343, 169-176.

M enache M G, M iller FJ and R aabe O G (1995). Particle inhalability curves for humans and small laboratory animals. Ann O ccup H yg 39, 317-328.

M iller K A, Siscovick D S, Sheppard LS, Shepherd K, Sullivan JH, Anderson $G L$, and $K$ aufman JD (2007). L ong-term exposure to air pollution and incidence of cardiovascular events in women. N ew Eng J M ed 356, 447-458.

M olnár $P, G$ ustafson $P$, Johanneson $S$, Boman J, Barregård $L$ and Sällsten $G$ (2005). D omestic wood burning and PM 2.5 trace elements: Personal exposures, indoor and outdoor levels. A tmos E nviron 39, 2643-2653.

M ST (2007). Personal communication.

M umford JL, HeXZ and Chapman RS (1990a). Human lung cancer risks due to complex organic mixtures of combustion emissions. R ecent R esults Cancer Res 120, 181-189.

M umford JL, H elmes CT, L ee X M, Seidenberg J and N esnow S (1990b). $M$ ouse skin tumorigenicity studies of indoor coal and wood combustion emissions from homes of residents in $\mathrm{X}$ uan $\mathrm{W}$ ei, $\mathrm{C}$ hina with high lung cancer mortality. Carcinogenesis 11, 397-403.

M usthapa M S, L ohani M , T iwari S, M athur N, Prasad R and Rahman Q (2004). Cytogenetic biomonitoring of Indian women cooking with biofuels: micronucleus and chromosomal aberration tests in peripheral blood lymphocytes. Environ M ol M utagen 43, 243-249.

$N$ aeher $L P, B$ rauer $M, L$ ipsett $M$, Zelikoff JT, Simpson CD, K oenig JQ and Smith KR (2007). W oodsmoke health effects: A review. Inhal T oxicol 19, 67106.

$\mathrm{N}$ afstad $\mathrm{P}, \mathrm{H}$ aheim $\mathrm{L} L$, W isloff $\mathrm{T}, \mathrm{G}$ ram $\mathrm{F}, \mathrm{O}$ ftedal $\mathrm{B}, \mathrm{H}$ olme I, $\mathrm{H}$ jermann I and $L$ eren $P$ (2004). $U$ rban air pollution and mortality in a cohort of N orwegian men. Environ $\mathrm{H}$ ealth Perspect 112, 610-615.

N ieman G F, Clark W R Jr., G oyette D , H art AK and Bredenberg CE (1989). W ood smoke inhalation increases pulmonary microvascular permeability. Surgery 105, 481-487.

N ikula KJ, Snipes M B, Barr EB, G riffith W C, Henderson RF and M auderly $J L$ (1995). C omparative pulmonary toxicities and carcinogenicities of 
chronically inhaled diesel exhaust and carbon black in $\mathrm{F} 344$ rats. F undam Appl T oxicol 25, 80-94.

N orris G, Y oung Pong SN , K oenig JQ , L arson T V, Sheppard L and Stout JW (1999). An association between fine particles and asthma emergency department visits for children in Seattle. Environ H ealth Perspect 107, 489493.

Oberdörster G, Ferin J, G elein R, Soderholm SC and Finkelstein J (1992). R ole of the alveolar macrophage in lung injury: studies with ultrafine particles. Environ H ealth Perspect 97, 193-199.

O berdörster G, Sharp Z, A tudorei V, Elder A, G elein R, L unts A, K reyling $W$ and Cox C (2002). Extrapulmonary translocation of ultrafine carbon particles following whole-body inhalation exposure of rats. J T oxicol Environ Health A 65, 1531-1543.

O rozco-L evi M , G arcia-A ymerich J, Villar J, Ramírez-Sarmineto A, Antó JM and $G$ ea J (2006). W ood smoke exposure and risk of chronic obstructive pulmonary disease. Eur R espir J 27, 542-546.

O stro BD, Lipsett M J, M ann JK, W iener M B and Selner J (1994). Indoor air pollution and asthma. Results from a panel study. A m J Respir C rit C are M ed 149, 1400-1406.

Ozturk S, Vatansever S, C efle K, Palanduz S, G uler K, Erten N, Erk O, $K$ aran M A and T ascioglu C (2002). A cute wood or coal exposure with carbon monoxide intoxication induces sister chromatid exchange. J T oxicol Clin T oxicol 40, 115-120.

Palmgren $F$, W ahlin $P$, Berkowicz $R, K$ etzel $M$, Illerup JB, N ielsen $M$, W inther M , G lasius M and Jensen B (2003). Aerosols in D anish Air (AID A). $M$ id-term report 2000-2002. N ational Environmental R esearch Institute. NERI T echnical Report 460.

Palmgren $F, G$ lasius $M$, W åhlin P, K etzel M , Berkowicz R, Jensen PS, W inther $M$, Illerup JB, A ndersen M S, H ertel $O$, Vinzents PS, $M$ øller $P$, Sørensen $M, K$ nudsen LE, Schibye $B, A$ ndersen ZJ, H ermansen $M$, Scheike $T$, Stage $M$, Bisgaard $H$, L oft $S$, Jensen $K A, K$ ofoed-Sørensen $V$ and $C$ lausen PA (2005). L uftforurening med partikler i D anmark. M iljøstyrelsen, M iljøprojekt N r. 1021.

Park E and L ee K (2003). Particulate exposure and size distribution from wood burning stoves in C osta Rica. Indoor Air 13, 253-259.

Park M S, C ancio L C, Jordan BS, B rinkley W W, Rivera VR and D ubick M A (2004). A ssessment of oxidative stress in lungs from sheep after inhalation of wood smoke. T oxicology 195, 97-112.

Pekkanen J, Peters A, H oek G, T iittanen P, Brunekreef B, de H artog J, $H$ einrich J, I bald-M ulli A, K reyling W G , L anki T, T imonen $K L$ and $V$ anninen $E$ (2002). Particulate air pollution and risk of ST -segment depression during repeated submaximal exercise tests among subjects with coronary heart disease: the Exposure and R isk A ssessment for Fine and 
U Itrafine Particles in A mbient Air (ULTRA) study. Circulation 106, 933938.

Perez-Padilla R, R egalado J, V edal S, Pare P, C hapela R, Sansores R and Selman M (1996). Exposure to biomass smoke and chronic airway disease in M exican women. A case-control study. Am J R espir C rit C are M ed 154, 701706.

Pintos J, Franco EL, K owalski LP, O liveira BV and C urado M P (1998). U se of wood stoves and risk of cancers of the upper aero-digestive tract: a casecontrol study. Int J E pidemiol 27, 936-940.

Pope CA III and D ockery DW (1999). Epidemiology of particle effects. In: $\mathrm{H}$ olgate ST, Samet JM and K oren HSM R (eds.). Air pollution and health. A cademic Press, L ondon, 673-705.

Pope CA III, T hun M J, N amboodiri M M , D ockery D W , Evans JS, Speizer FE and H eath CW Jr. (1995). Particulate air pollution as a predictor of mortality in a prospective study of U.S. adults. A m J R espir C rit C are M ed $151,669-674$.

Pope CA III, Burnett RT, T hun M J, Calle EE, K rewski D, Ito $K$ and T hurston GD (2002). L ung cancer, cardiopulmonary mortality, and longterm exposure to fine particulate air pollution. JA M A 287, 1132-1141.

Prevedouros K, Brorstrom- L unden $E, H$ alsall J, Jones K C, L ee R G and Sweetman AJ (2004). Seasonal and long-term trends in atmospheric PAH concentrations: evidence and implications. Environ Pollut 128, 17-27.

R amanakumar AV, Parent M -E and Siemiatycki (2006). R isk of lung cancer from residential heating and cooking fuels in $M$ ontreal, C anada. A $\mathrm{m} J$ E pid $165,634-642$.

Reed M D , Campen M J, G igliotti AP, H arrod KS, M cD onald JC, Seagrave JC, M auderly JL and Seilkop SK (2006). H ealth effects of subchronic exposure to environmental levels of hardwood smoke. Inhal T oxicol 18, 523539.

Rogge W F, Hildemann L M , M azurek M A, Cass G R and Simoneit BR (1998). Sources of fine organic aerosol. 9. Pine, oak, and synthetic log combustion in residential fireplaces. Environ Sci T echnol 32, 13-22.

R aaschou- $\mathrm{N}$ ielsen $\mathrm{O}, \mathrm{Palmgren} \mathrm{F}$, Jensen $\mathrm{SS}, \mathrm{W}$ åhlin $\mathrm{P}$, Berkowitz $\mathrm{R}, \mathrm{H}$ ertel $O, V$ rang $M-L$ and L oft S (2002). H elbredseffekter af partikulaær luftforurening I D anmark - et forsøg på kvantificering. U geskr L æger 164, 3959-3963.

Sällsten G, G ustafson P, Johansson L , Johannesson S, M olnár P, Strandberg $B$, T ullin $C$ and Barregard $L$ (2006). Experimental wood smoke exposure in humans. Inhal T oxicol 18, 855-864.

Sarangapani R and W exler AS (2000). T he role of dispersion in particle deposition in human airways. T oxicol Sci 54, 229-236. 
Schauer JJ, K leeman M J, C ass G R and Simoneit BRT (2001). M easurement of emissions from air pollution sources. 3. $\mathrm{C}_{1}-\mathrm{C}_{29}$ organic compounds from fireplace combustion of wood. Environ Sci T echnol 35, 1716-1728.

Schei M A, H essen JO, Smith K R, Bruce N , M cC racken J and L opez V (2004). Childhood asthma and indoor woodsmoke from cooking in Guatemala. J Expo Anal Environ Epidemiol 14, S110-S117.

Schlesinger R B (1985). Comparative deposition of inhaled aerosols in experimental animals and humans: a review. J T oxicol Environ $\mathrm{H}$ ealth 15 , 197-214.

Schlesinger R B (2000). D isposition of inhaled particles and gases. In: C ohen $M$, Zelikoff J and Schlesinger RB (eds.). Pulmonary Immunotoxicology. K luwer A cademic Publishers.

Schlesinger RB and C assee $F$ (2003). Atmospheric secondary inorganic particulate matter: the toxicological perspective as a basis for health effects risk assessment. Inhal T oxicol 15, 197-235.

Schreuder AB, L arson T V, Sheppard L and Claiborn C S (2006). A mbient woodsmoke and associated respiratory emergency department visits in Spokane, W ashington. Int J O ccup Environ Health 12, 147-153.

Schwartz J, Slater D, L arson T V, Pierson WE and K oenig JQ (1993). Particulate air pollution and hospital emergency room visits for asthma in Seattle. Am Rev Respir D is 147, 826-831.

Seagrave JC, M CD onald JD, R eed M D, Seilkop SK and M auderly JL (2005). R esponses to subchronic inhalation of low concentrations of diesel exhaust and hardwood smoke measured in rat bronchoalveolar lavage fluid. Inhal T oxicol 17, 657-670.

Sheppard L, L evy D, N orris G , L arson T V and K oenig JQ (1999). Effects of ambient air pollution on nonelderly asthma hospital admissions in Seattle, W ashington, 1987-1994. Epidemiology 10, 23-30.

Slaughter JC , K oenig JQ and R einhardt T E (2004). Association between lung function and exposure to smoke among firefighters at prescribed burns. J Occup Environ $\mathrm{H}$ yg 1, 45-49.

Smith K R, Samet JM, R omieu I and Bruce N (2000). Indoor air pollution in developing countries and acute lower respiratory infections in children. Thorax 55, 518-532.

Snipes M B (1989). L ong-term retention and clearance of particles inhaled by mammalian species. C rit Rev T oxicol, 20, 175-211.

Stahlhofen W , G ebhart J and H eyder J (1980). Experimental determination of the regional deposition of aerosol particles in the human respiratory tract. Am Ind Hyg A ssoc J 41, 385-398a.

Statistics D enmark (2007). www.dst.dk 
Sternhufvud C, K arvosenoja N , Illerup JB, K indbom K , L ükewille A, Johansson M and Jensen D. (2004). Particulate matter emissions and abatement options in residential wood burning in the $\mathrm{N}$ ordic countries. N ordic C ouncil of M inisters, AN P, 2004.

Stölzel M , Breitner S, C yrys J, Pitz M , W ölke G, K reyling W, H einrich J, W ichmann $\mathrm{H}-\mathrm{E}$ and Peters A (2006). D aily mortality and particulate matter in different size classes in Ehrfurt, G ermany. J Exp Sci Environ Epid, 1-10.

T esfaigzi $Y$, Singh SP, F oster JE, K ubatko J, Barr EB, Fine PM , M CD onald JD, Hahn FF and M auderly JL (2002). H ealth effects of subchronic exposure to low levels of wood smoke in rats. T oxicol Sci 65, 115-125.

T esfaigzi $Y, M$ CD onald JD, R eed M D , Singh SP, D e Sanctis G T , Eynott PR, $\mathrm{H}$ ahn FF, Campen M J and M auderly JL (2005). L ow-level subchronic exposure to wood smoke exacerbates inflammatory responses in allergic rats. T oxicol Sci 88, 505-513.

Thorning D R, H oward M L, Hudson LD and Schumacher RL (1982). Pulmonary responses to smoke inhalation: morphologic changes in rabbits exposed to pine wood smoke. Hum Pathol 13, 355-364.

T rafikministeriet (2003). Partikelredegørelse. Bilag 2: Vurdering af partikelforureningens og dieselpartiklers sundhedsskadelige effekter. Miljøministeriets og Sundhedsstyrelsens arbejdsgruppe for udendørs luftforurening april 2003; http://www.trm.dk/graphics/Synkron-

Library/trafikministeriet/Publikationer/pdf/Partikelredegorelse2.pdf

U S-EPA (2006). N ational A mbient Air Quality Standards (N AAQS). http://www.epa.gov/air/criteria.html

Valberg PA and Long CM (2003). Is PM more toxic than the sum of its parts? D iscordance between "Effect functions" for PM mass versus riskassessment toxicity factors. Poster P12-05 at the PM AAAR 2003 Conference, Pittsburgh M arch 31- April 4.

V edal S, Petkau J, W hite R and Blair J (1998). A cute effects of ambient inhalable particles in asthmatic and nonasthmatic children. Am J Respir C rit Care M ed 157, 1034-1043.

Vikelsøe J, H ovmand M F, A ndersen H V, Bossi R, Johansen E and Chrillesen $M-A$ (2005). D ioxin in the atmosphere of D enmark. A field study at selected locations. N ERI T echnical Report N 0. 565.

Vineis P, Forastiere F, H oek $G$ and L ipsett M (2004). O utdoor air pollution and lung cancer: recent epidemiologic evidence. Int J C ancer 111, 647-652.

W ichmann HE, Spix C , T uch T, W olke G, Peters A, H einrich J, K reyling W G and Heyder J (2000). D aily mortality and fine and ultrafine particles in Ehrfurt, G ermany, Part I: role of particle number and particle mass. Research Report ( $\mathrm{H}$ ealth Effects Institute), 5-86, discussion 87-94.

W HO (2003). H ealth aspects of air pollution with particulate matter, ozone and nitrogen dioxide. Report from a WHO working group, Bonn, G ermany, 13-15 January 2003. 
WHO (2004). Health aspects of air pollution - answer to follow-up questions from CAFÉ. Report from a WHO working group, Bonn, G ermany, 15-16 January 2004.

WHO (2006). W H O Air Q uality G uidelines for particulate matter, ozone, nitrogen dioxide and sulphur dioxide, global update 2005, summary of risk assessments

W ong K L, Stock M F, M alek DE and Alarie Y (1984). Evaluation of the pulmonary effects of wood smoke in guinea pigs by repeated $\mathrm{CO}_{2}$ challenges. T oxicol Appl Pharmacol 75, 69-80.

Y u O, Sheppard L, L umley T, K oenig JQ and Shapiro G G (2000). Effects of ambient air pollution on symptoms of asthma in Seattle-area children enrolled in the CAM P study. Environ H ealth Perspect 108, 1209-1214.

Zanobetti A, Schwartz J, Samoli E, G ryparis A, T ouloumi G , Peacock J, Anderson RH, L e T ertre A, Bobros J, Celko M, Goren A, Forsberg B, $M$ ichelozzi P, Rabczenko D , H oyos SP, W ichmann HE and $K$ atsouyanni $K$ (2003). T he temporal pattern of respiratory and heart disease mortality in response to air pollution. Environ H ealth Perspect 111, 1188-1193.

Zelikoff JT, Baker K, C ohen M D and Chen LC (1995a). W ood smoke emissions: Effects on pulmonary immune defence. T oxicologist 256, 15.

Zelikoff JT , Baker K, C ohen M D and C hen LC (1995b). Inhalation of wood smoke compromises pulmonary host resistance against bacterial infections. Am Rev Respir D is 150, 89.

Zelikoff JT , C hen L C , C ohen M D and Schlesinger RB (2002). T he toxicology of inhaled wood smoke. J T oxicol Environ $\mathrm{H}$ ealth $\mathrm{B} \mathrm{C}$ rit R ev 5, 269-282. 